\title{
Impact of Stereo- and Regiochemistry on
}

\section{Energetic Materials}

Lisa M. Barton ${ }^{\dagger}$, Jacob T. Edwards ${ }^{\dagger}$, Eric C. Johnson ${ }^{\ddagger}$, Eric J. Bukowski ${ }^{\ddagger}$, Rosario C. Sausa ${ }^{\S}$, Edward F. C. Byrd ${ }^{\S}$, Joshua A. Orlicki ${ }^{\ddagger}$, Jesse J. Sabatini, ${ }^{*}+$ and Phil S. Baran ${ }^{* \dagger}$

$\dagger$ Department of Chemistry, Scripps Research, 10550 North Torrey Pines Road, La Jolla, California 92037

+ CCDC US Army Research Laboratory, Energetics Synthesis \& Formulation Branch, Aberdeen Proving Ground, MD 21005

$\S$ CCDC US Army Research Laboratory, Detonation Sciences \& Modeling Branch, Aberdeen Proving Ground, MD 21005

$\neq$ CCDC US Army Research Laboratory, Polymers Branch, Aberdeen Proving Ground, MD 21005 


\section{Table of Contents}

GENERAL EXPERIMENTAL .........................................................................................

OVERALL SYNTHETIC ROUTES ....................................................................................... S6

Scheme S1: Synthesis of Cis-Trans-Cis and All-Trans Tetranitrates ................................................ S6

Scheme S2: Synthesis of Cis-Cis-Trans Tetranitrates ......................................................................... S7

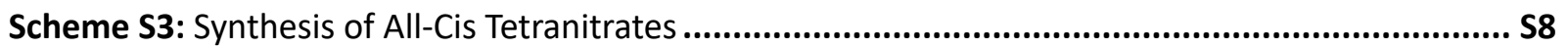

Scheme S4: Synthesis of 1,1,2,2 Tetranitrates ................................................................................ S9

Scheme S5: Synthesis of 1,1,3,3 Tetranitrates ................................................................................. S9

SYNTHETIC PROCEDURES AND CHARACTERIZATION DATA ...................................S10

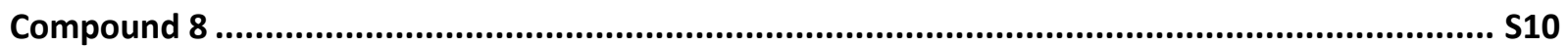

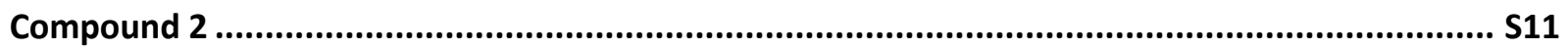

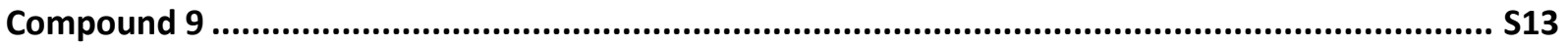

Graphical Supporting Information for the Synthesis of Compounds 8 and 9 ............................... S14

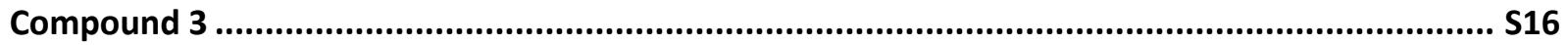

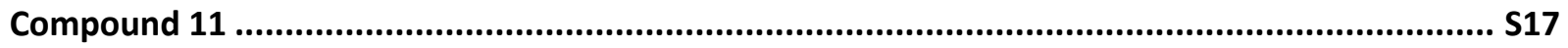

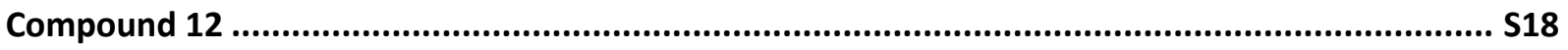

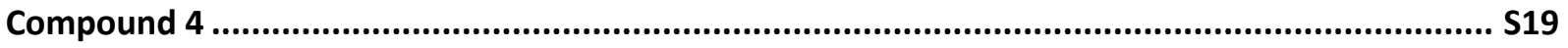

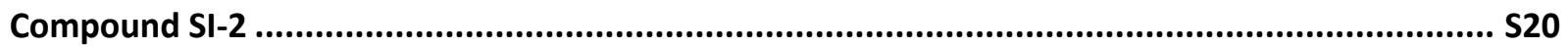

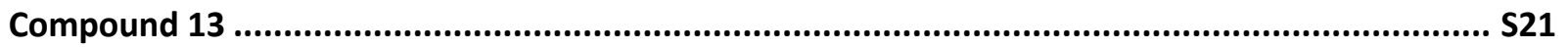

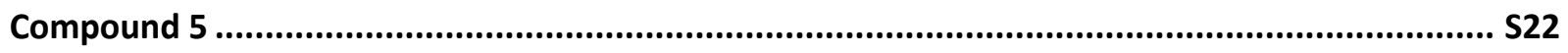

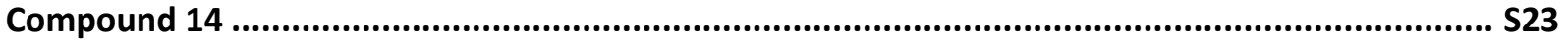

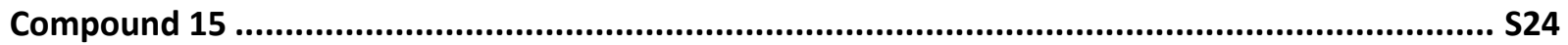

Graphical Supporting Information for Electrochemical Cyclization to Afford Compound 15 .......... S25

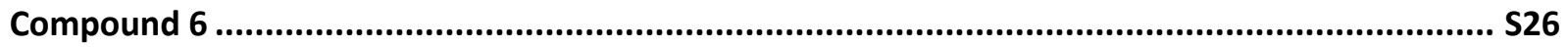

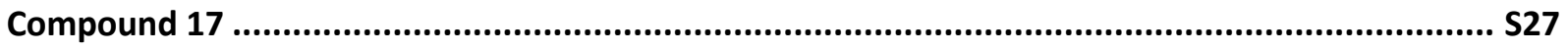

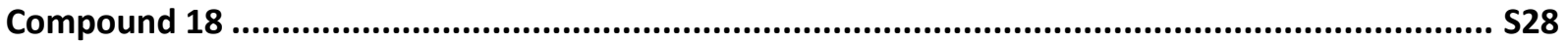

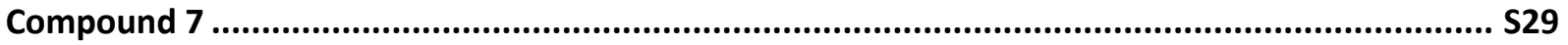

X-RAY CRYSTALLOGRAPHIC DATA ......................................................................... S30

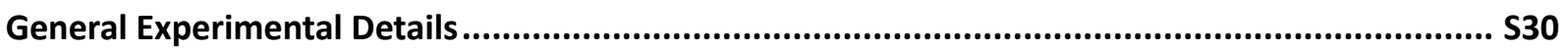




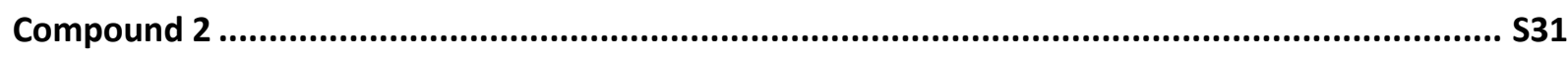

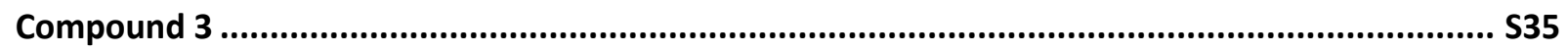

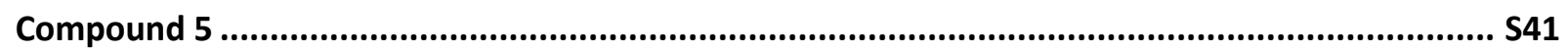

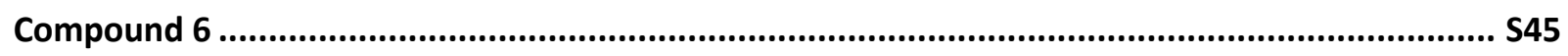

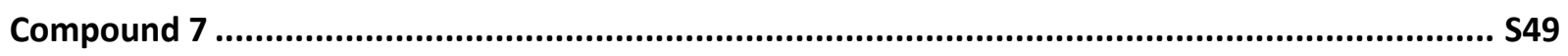

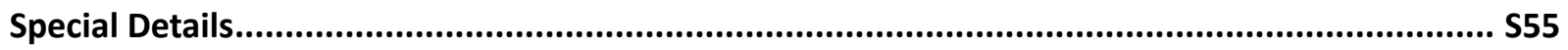

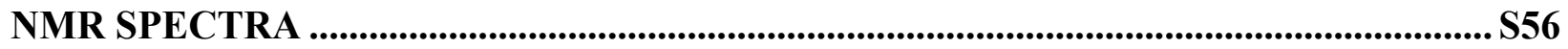

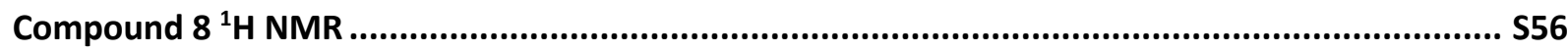

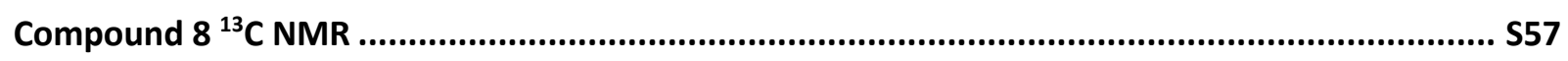

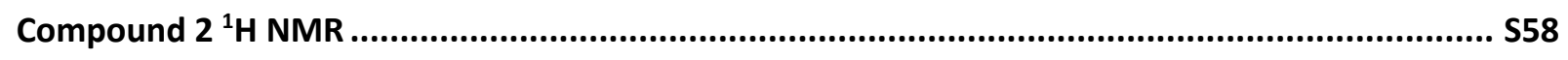

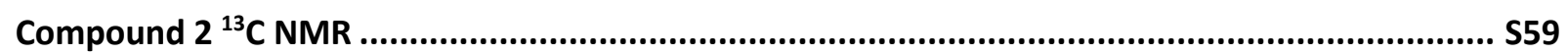

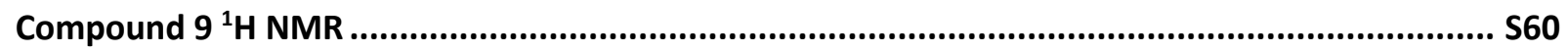

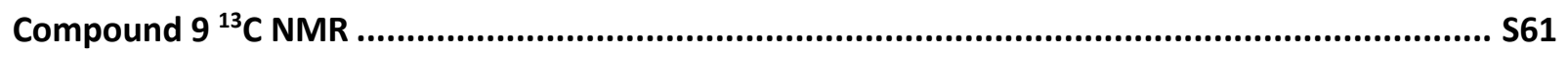

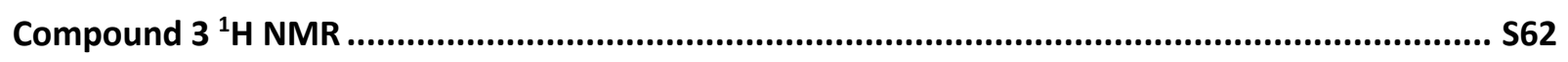

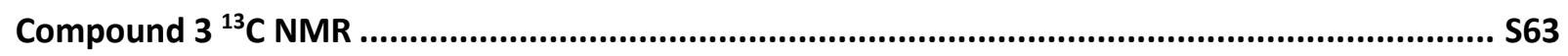

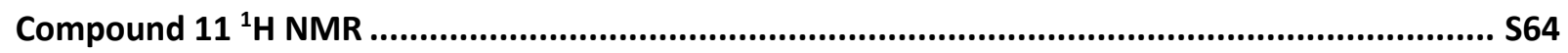

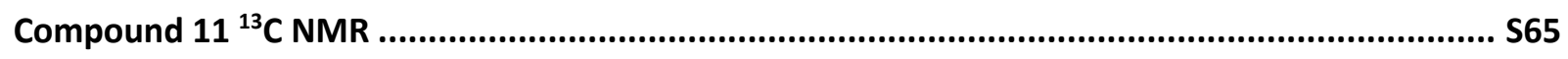

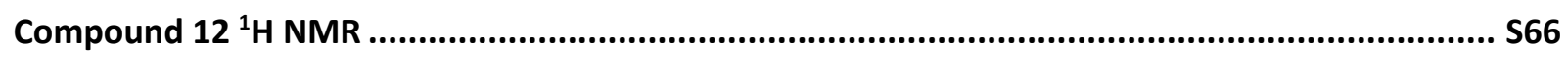

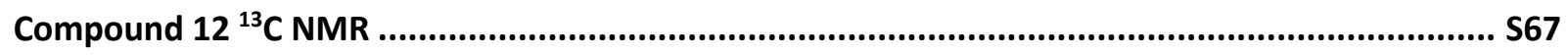

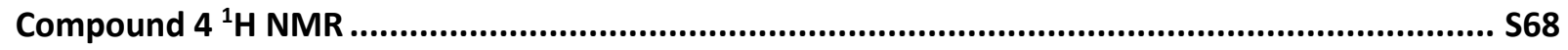

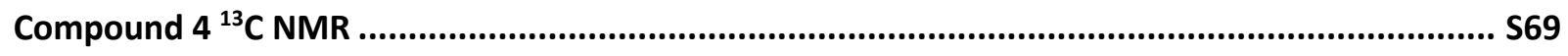

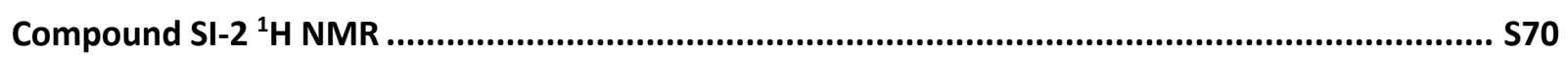

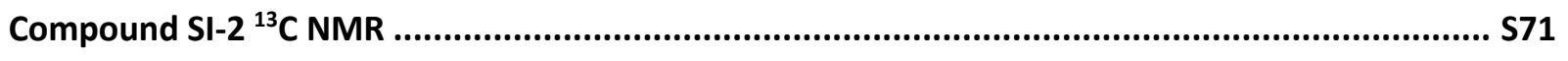

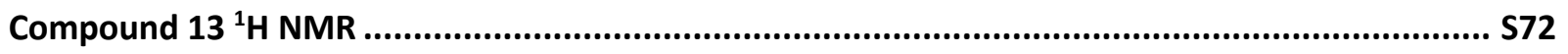

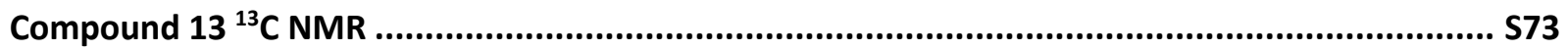

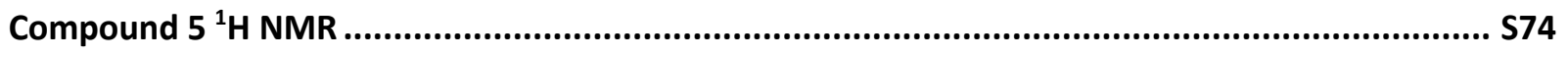

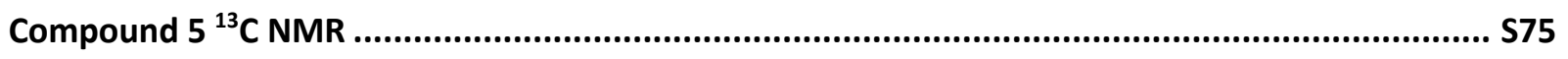

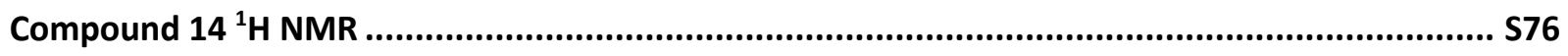

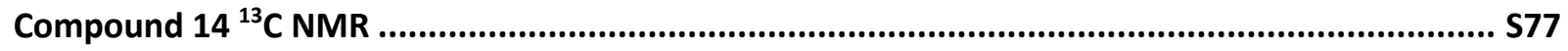

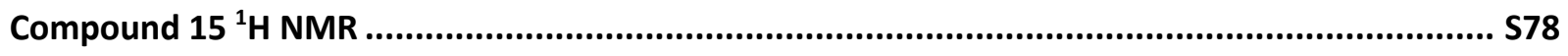

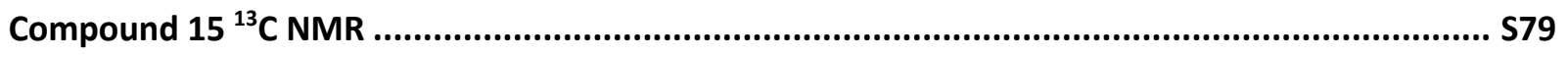




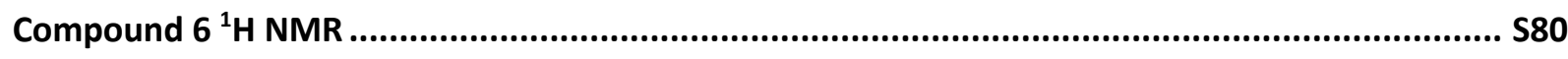

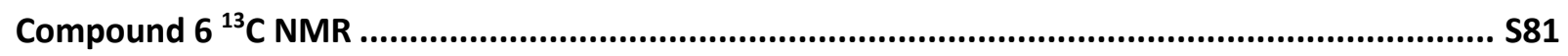

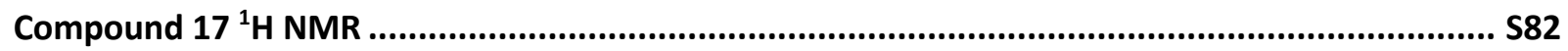

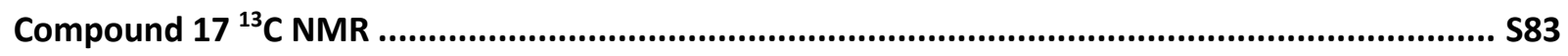

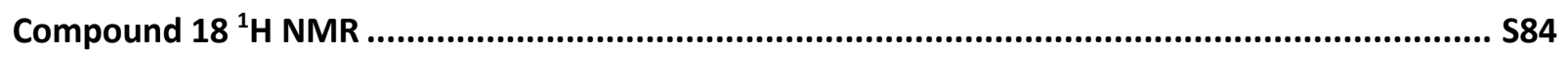

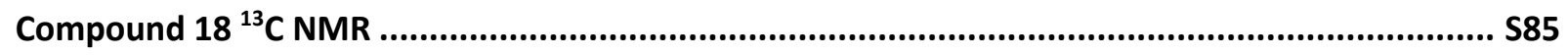

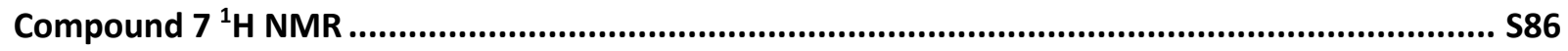

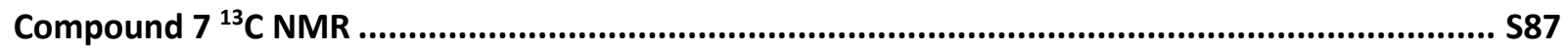

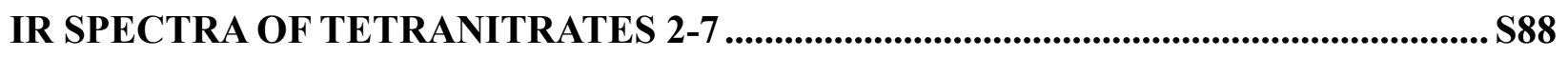

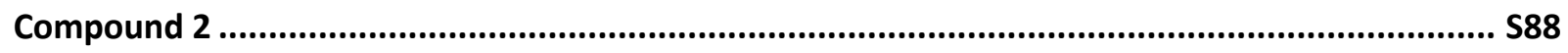

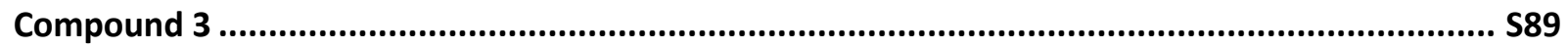

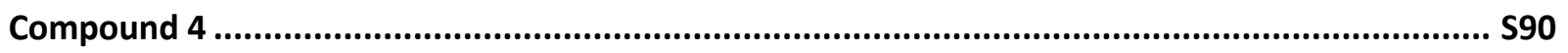

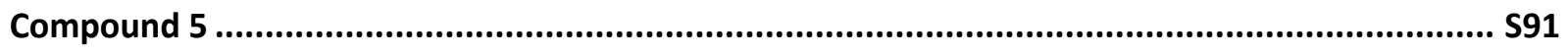

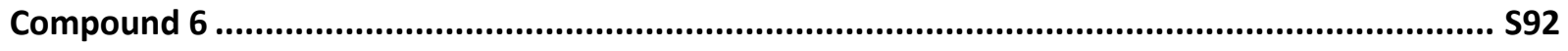

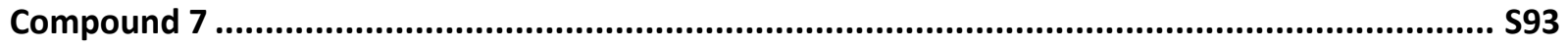

DSC TRACES OF TETRANITRATES 2-7 ...............................................................S94

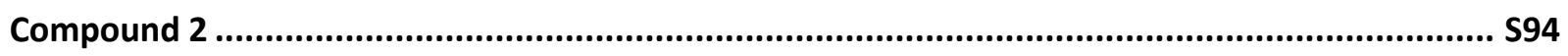

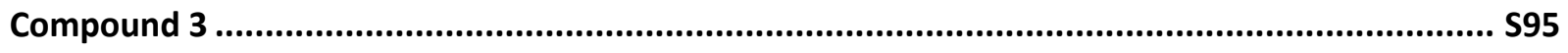

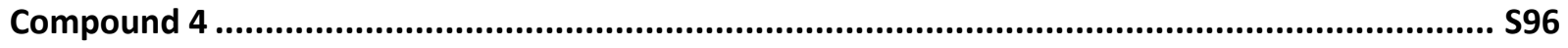

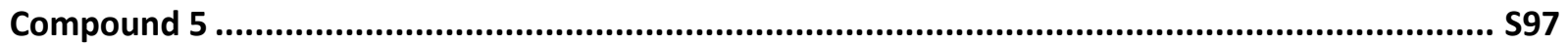

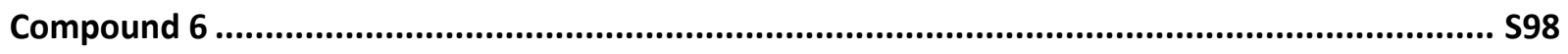

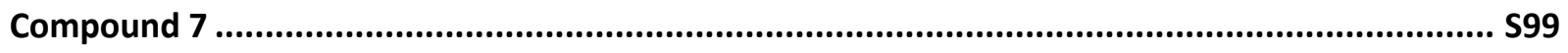

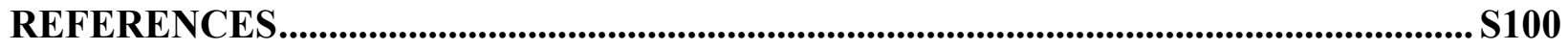




\section{General Experimental}

Tetrahydrofuran (THF), $\mathrm{N}, \mathrm{N}$-dimethylformamide (DMF), toluene, acetonitrile $\left(\mathrm{CH}_{3} \mathrm{CN}\right)$, and dichloromethane $\left(\mathrm{CH}_{2} \mathrm{Cl}_{2}\right)$ were obtained by passing the previously degassed solvents through an activated alumina column. Reagents were purchased at the highest commercial quality grade and used without further purification, unless otherwise stated. Yields refer to chromatographically and spectroscopically ( ${ }^{1} \mathrm{H}$ NMR) homogeneous material, unless otherwise stated. The reactions were monitored by GC/MS, ${ }^{1} \mathrm{H}$ NMR, and thin layer chromatography (TLC). TLC was performed using $0.25 \mathrm{~mm}$ E. Merck Silica plates (60F-254), using short-wave UV light as the visualizing agent, acidic ethanolic anisaldehyde, or $\mathrm{KMnO}_{4}$ and heat as developing agents. NMR spectra were recorded on Bruker DRX-600 and Bruker $400 \mathrm{MHz}$ Avance III HD Magnet instruments and are calibrated using residual undeuterated solvent $\left(\mathrm{CHCl}_{3}\right.$ at $7.26 \mathrm{ppm}{ }^{1} \mathrm{H}$ NMR, $77.16 \mathrm{ppm}{ }^{13} \mathrm{C} \mathrm{NMR}$; acetone- $\mathrm{d}_{6}$ at $2.05 \mathrm{ppm}{ }^{1} \mathrm{H}$ NMR, $29.84 \mathrm{ppm}{ }^{13} \mathrm{C}$ NMR). The following abbreviations were used to explain multiplicities: $\mathrm{s}=$ singlet, $\mathrm{d}=$ doublet, $\mathrm{t}=$ triplet, $\mathrm{q}=$ quartet, $\mathrm{m}=$ multiplet, $\mathrm{br}=$ broad. Column chromatography was performed using E. Merck Silica (60, particle size $0.043-0.063 \mathrm{~mm}$ ). High-resolution mass spectra (HRMS) were recorded on an Agilent LC/MSD TOF mass spectrometer by electrospray ionization time of flight reflectron experiments. Melting points were recorded on a Fisher-Johns 12-144 melting point apparatus and are uncorrected. Infrared spectra were measured with a Bruker Alpha-P FTIR instrument. Melting and decomposition temperatures of tetranitrates were measured at a heating rate of $5{ }^{\circ} \mathrm{C} / \mathrm{min}$ using a TA Instruments Q10 DSC instrument. Single crystal x-ray diffraction studies for compounds 2-3 and 5-7 were performed with a SuperNova Dualflex diffractometer containing an EosS2 charge-couple device detector and a molybdenum Mo-Ka $(\lambda=0.71073 \AA)$ radiation source. CCDC numbers 1935553 (for 2), 1935554 (for 3), 1935555 (for 5), 1935556 (for 6), and 1935557 (for 7) contain the supplementary crystallographic data for this paper. These data can be obtained free of charge from the Cambridge Crystallographic Data Centre. 


\section{Overall Synthetic Routes}

Scheme S1: Synthesis of Cis-Trans-Cis and All-Trans Tetranitrates<smiles>COC(=O)/C=C/C(=O)OC</smiles><smiles>COCC1[C@H](C(OC)OC)[C@H](COC)[C@H]1C(OC)OC</smiles>

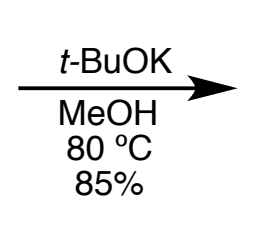<smiles>COCC1[C@H](OC)[C@H](COC)[C@H]1C(OC)OC</smiles><smiles>OC[C@H]1[C@@H](CO)[C@@H](CO)[C@H]1CO</smiles>

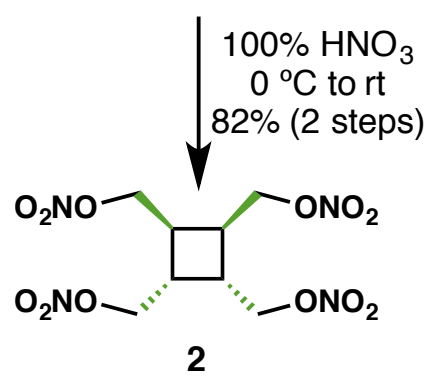

[cis-trans-cis]
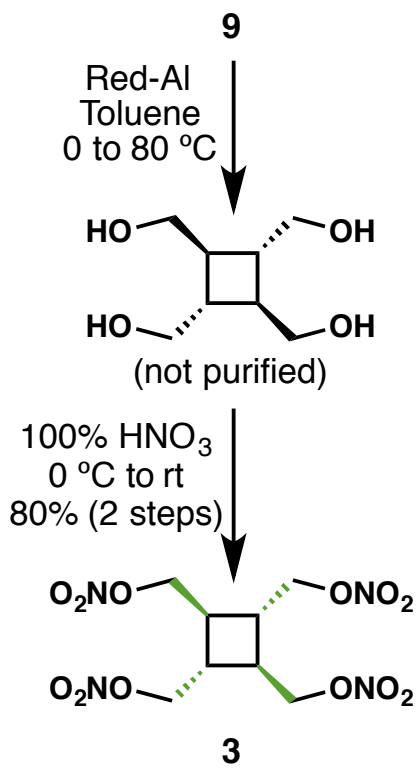

[all trans] 
Scheme S2: Synthesis of Cis-Cis-Trans Tetranitrates

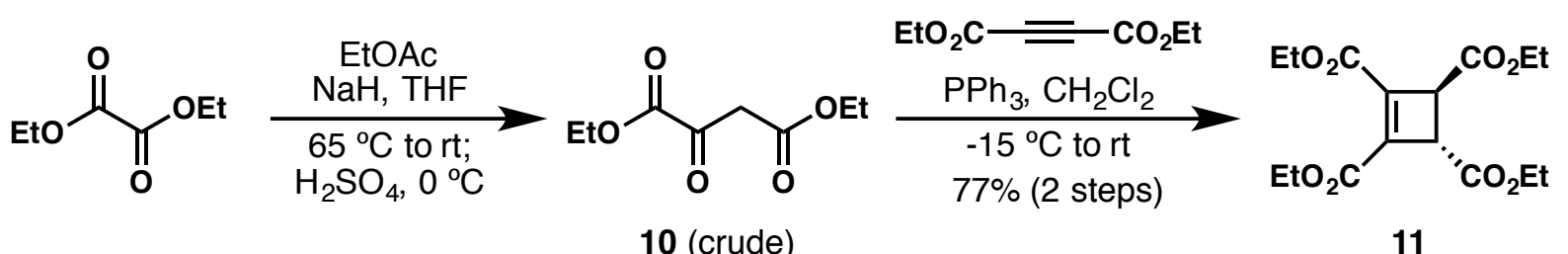

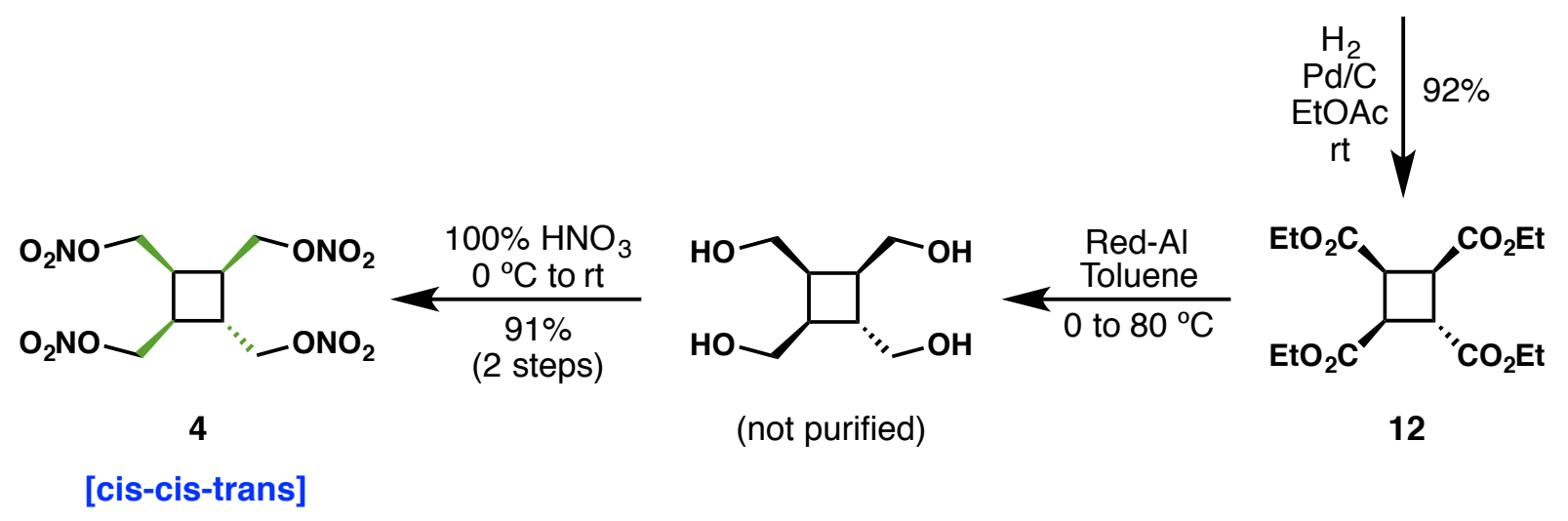


Scheme S3: Synthesis of All-Cis Tetranitrates
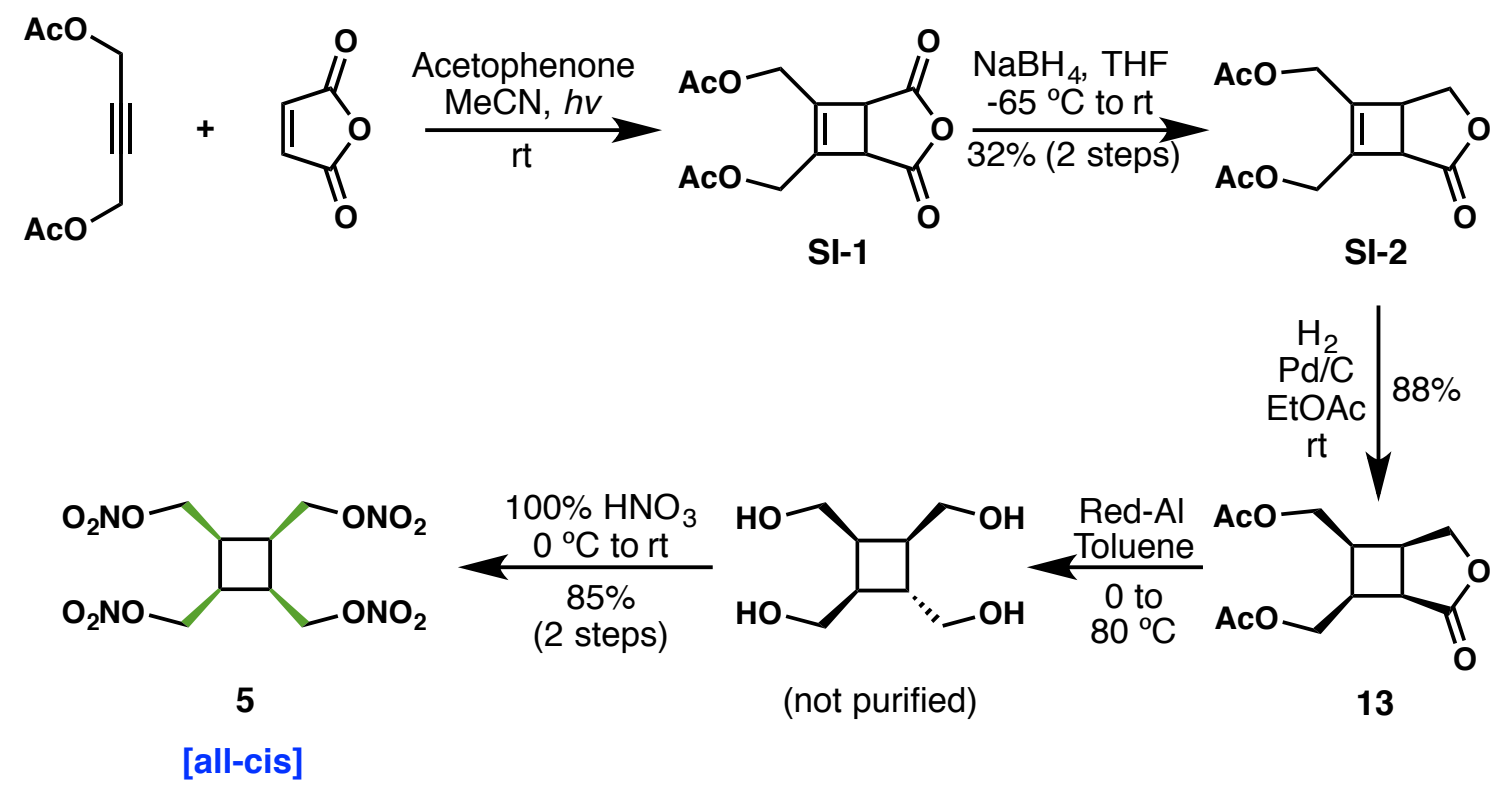
Scheme S4: Synthesis of 1,1,2,2 Tetranitrates

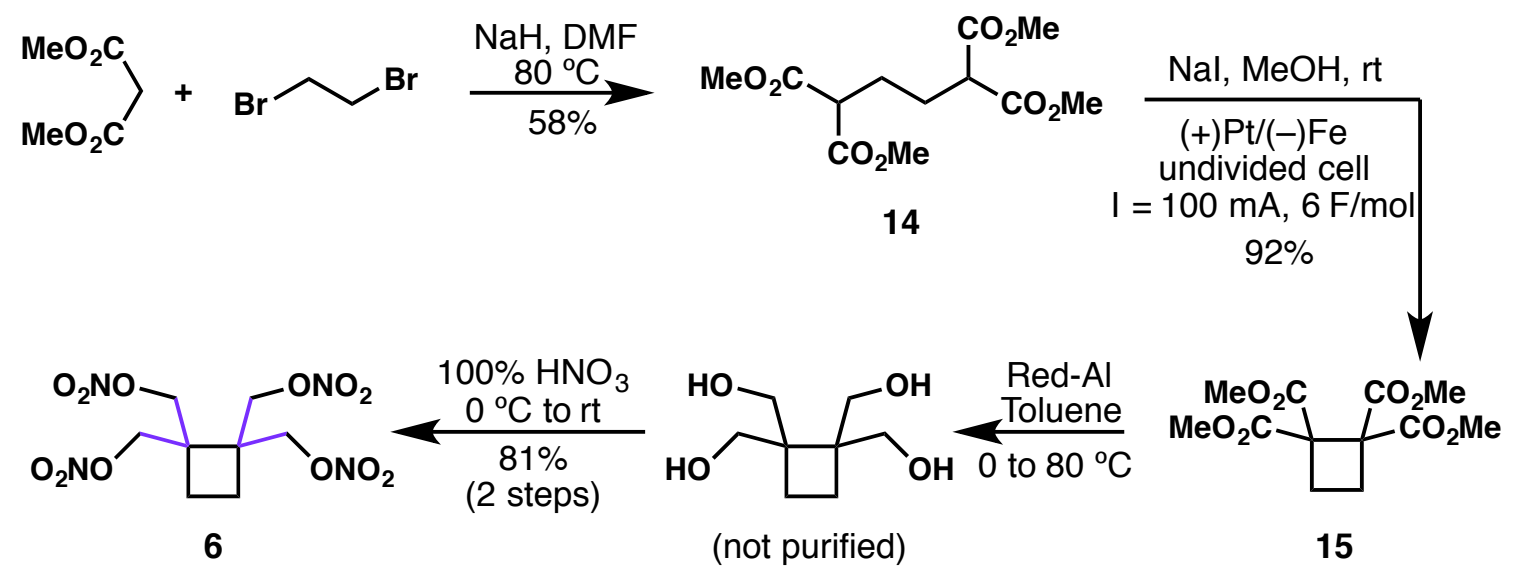

$[1,1,2,2]$

Scheme S5: Synthesis of 1,1,3,3 Tetranitrates
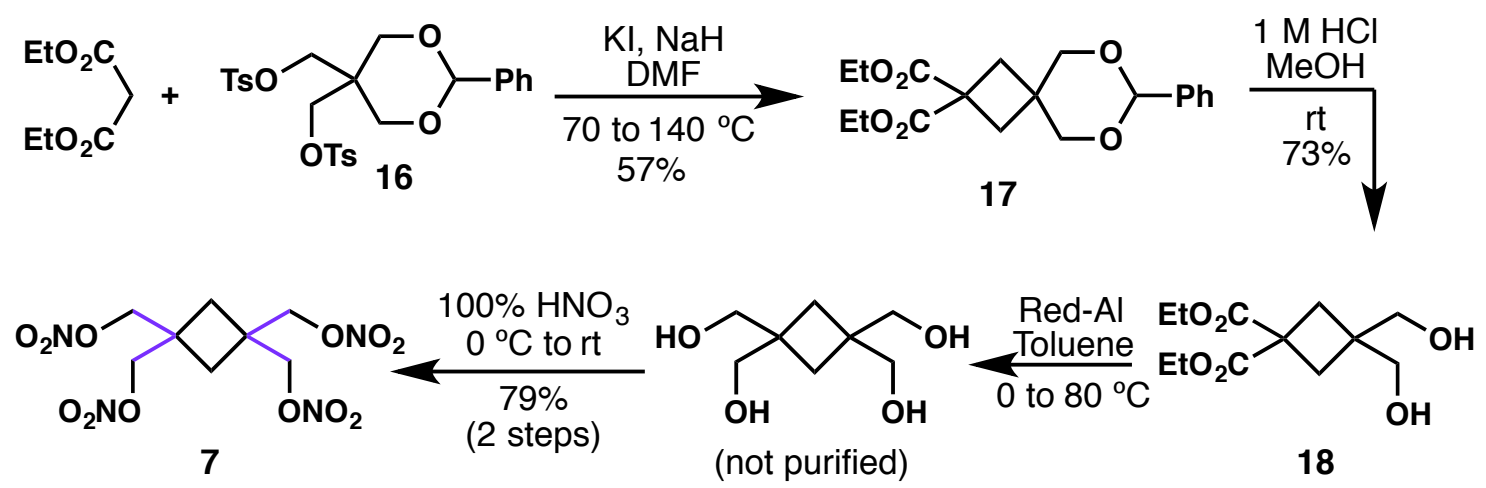

$[1,1,3,3]$ 


\section{Synthetic Procedures and Characterization Data Compound 8}<smiles>COC(=O)/C=C/C(=O)OC</smiles>

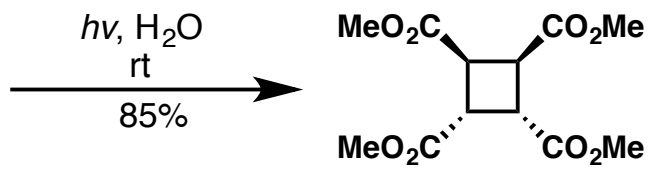

8

The following was modified from a previously reported procedure. ${ }^{1}$ A 1 Liter photochemical reaction vessel (\#7863) equipped with a quartz immersion well (\#7874) was charged with dimethyl fumarate $(80.0 \mathrm{~g}, 555 \mathrm{mmol})$ and $\mathrm{H}_{2} \mathrm{O}(800 \mathrm{~mL})$. The suspension was vigorously stirred and irradiated with a mercury lamp at room temperature for 72 hours or until complete consumption of starting matieral was observed by ${ }^{1} \mathrm{H}$ NMR. The resulting white solid was collected by filtration and washed with $\mathrm{H}_{2} \mathrm{O}$ (2x $200 \mathrm{~mL}$ ), followed by cold $\mathrm{MeOH}(1 \times 200 \mathrm{~mL})$ and $\mathrm{Et}_{2} \mathrm{O}$ (1x $200 \mathrm{~mL}$ ). The solid was then azeotroped with toluene to ensure no residual $\mathrm{H}_{2} \mathrm{O}$ remained to afford $68.0 \mathrm{~g}$ $(85 \%)$ of the title compound 8 . This procedure was repeated multiple times in order to provide over 1.0 kilograms of compound $\mathbf{8}$.

Physical State: white solid.

m.p.: $125-132{ }^{\circ} \mathrm{C}$.

${ }^{1}$ H NMR (600 MHz, $\left.\mathbf{C D C l}_{3}\right): \delta 3.76(\mathrm{~s}, 4 \mathrm{H}), 3.69$ (s, 12H) ppm.

${ }^{13} \mathrm{C}$ NMR (151 MHz, $\left.\mathbf{C D C l}_{3}\right): \delta 171.4,52.5,40.9 \mathrm{ppm}$.

HRMS (ESI-TOF): calc'd for $\mathrm{C}_{12} \mathrm{H}_{17} \mathrm{O}_{8}[\mathrm{M}+\mathrm{H}]^{+}: 289.0923$, found: 289.0928 .

TLC: $\mathrm{R}_{f}=0.31$ (2:1 hexanes/EtOAc). 


\section{Compound 2}

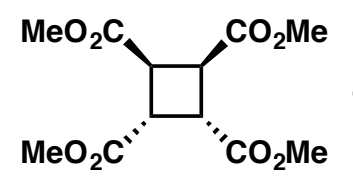

8

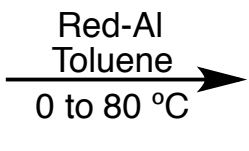

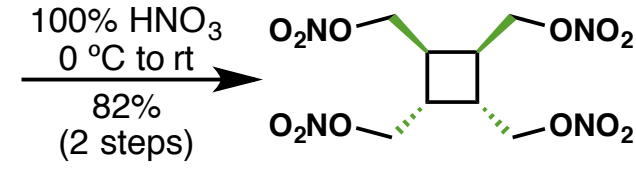

2

Caution! Although we did not experience any problems in performing the reaction described in this paper, proper laboratory precautions should be taken. Laboratories and personnel should be properly grounded, and safety equipment such as heavy Kevlar/steel gloves, reinforced Kevlar coat, ballistic face shield, ear plugs, and blast shields are necessary.

In a $250 \mathrm{~mL}$ three-neck round-bottom flask equipped with a reflux condenser and a mechanical stir bar was added $50 \mathrm{~mL}$ of toluene. A $60 \mathrm{wt} . \%$ solution of Red-Al in toluene $(17.5 \mathrm{~g}, 16.9 \mathrm{~mL}$, $52.1 \mathrm{mmol}, 5.00$ equiv.) was then added dropwise by means of a syringe over 30 minutes at room temperature. The flask was then immersed into an ice-water bath, and after 20 minutes, tetraester 8 ( $3 \mathrm{~g}, 10.4 \mathrm{mmol}, 1.00$ equiv.) was added in six-500 mg portions over the course of 1 hour. The ice-water bath was removed, and the reaction mixture was stirred for 1 hour at room temperature. The reaction mixture was then immersed in an oil bath, heated to $80^{\circ} \mathrm{C}$ and stirred for 16 hours. The heat was turned off, the reaction mixture was then cooled to room temperature, removed from the oil bath, placed in an ice-water bath, and cooled to $0{ }^{\circ} \mathrm{C}$.

With vigorous stirring, the reaction mixture was treated with $2.1 \mathrm{~mL}$ of $\mathrm{H}_{2} \mathrm{O}$, followed by 2.1 $\mathrm{mL}$ of a $15 \% \mathrm{NaOH}$ solution, followed by $6.3 \mathrm{~mL} \mathrm{H}_{2} \mathrm{O}$. After stirring for 1 hour, the solid that formed was collected by means of a Büchner funnel. The mother liquor was discarded, and the solid material was returned to the flask. $60 \mathrm{~mL}$ of $\mathrm{MeOH}$ was added, and the material was heated to reflux and stirred for 1 hour. After cooling the reaction to room temperature, the solid was collected by means of a Büchner funnel, and rinsed with two- $20 \mathrm{~mL}$ portions of $\mathrm{MeOH}$. The solid was discarded, and the mother liquor was concentrated in vacuo to afford $2.71 \mathrm{~g}$ of a white solid material. This solid was the presumed tetrol contaminated with aluminum salts, and was subjected to nitration conditions without further purification. 
$30 \mathrm{~mL}$ of $100 \% \mathrm{HNO}_{3}$ was poured into a three-neck $250 \mathrm{~mL}$ round-bottom flask and was cooled to $0{ }^{\circ} \mathrm{C}$ in an ice-water bath. $2.71 \mathrm{~g}$ of the above solid material was added portionwise over 1 hour at a rate such that the internal temperature did not rise above $15^{\circ} \mathrm{C}$. After complete addition of the solid, the reaction mixture was stirred for 1 hour at $0{ }^{\circ} \mathrm{C}$, the ice-water bath was removed, and the reaction mixture was stirred for an additional 3 hours at room temperature. The reaction mixture was poured onto crushed ice with stirring, and stirred for 2 hours during which time the ice melted and a white/yellow solid appeared. The solid was collected by Büchner funnel and was recrystallized from hot isopropanol to give tetranitrate $2(3.04 \mathrm{~g}, 82 \%)$ as a white solid.

Physical State: white solid.

m.p.: $106.0-109.6^{\circ} \mathrm{C}$.

$\mathbf{T}_{\text {dec }}$ (onset): $198.5^{\circ} \mathrm{C}$.

$\mathbf{T}_{\text {peak }}: 222.5^{\circ} \mathrm{C}$.

IR (neat): $\tilde{v}=2987.18(\mathrm{w}), 2961.77(\mathrm{w}), 2888.82(\mathrm{w}), 1618.35(\mathrm{~s}), 1274.06(\mathrm{~s}) \mathrm{cm}^{-1}$.

${ }^{1}$ H NMR (400 MHz, acetone-d 6 ): $\delta 4.85\left(\mathrm{ABX}, J_{\mathrm{AB}}=12 \mathrm{~Hz}, J_{\mathrm{AX}}=8 \mathrm{~Hz}, J_{\mathrm{BX}}=8 \mathrm{~Hz}, 8 \mathrm{H}\right), 3.01$ (s, 4H) ppm.

${ }^{13}$ C NMR (101 MHz, acetone-d 6 ): $\delta$ 73.0, $34.6 \mathrm{ppm}$. 


\section{Compound 9}

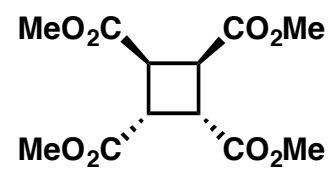

8

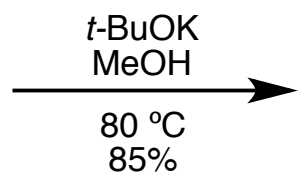

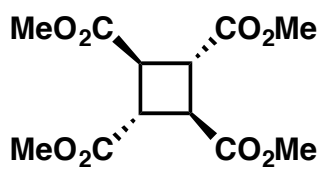

9

The following was modified from a previously reported procedure. ${ }^{2}$ Compound 8 (140.1 g, 486 mmol, 1 equiv.) was added to a round bottom flask and dispersed in anhydrous $\mathrm{MeOH}(1.6 \mathrm{~L}) . t$ $\mathrm{BuOK}$ (16.4 g, $146 \mathrm{mmol}, 0.3$ equiv.) was then added portionwise. The flask was connected to a reflux condenser and the suspension was heated to $80{ }^{\circ} \mathrm{C}$, at which point 8 fully dissolved into the solution, and the reaction was stirred at $80{ }^{\circ} \mathrm{C}$ for 24 hours. The reaction was then allowed to cool to room temperature and cooled to $-20{ }^{\circ} \mathrm{C}$ until product had fully precipitated from the solution. Product was collected via filtration and washed several times with cold $\mathrm{MeOH}$ to afford $118.7 \mathrm{~g}$ $(85 \%)$ of the title compound $\mathbf{9}$. This procedure was repeated multiple times in order to provide over 1.0 kilograms of compound 9.

Physical State: white solid

m.p.: $100-105^{\circ} \mathrm{C}$.

${ }^{1}$ H NMR (600 MHz, CDCl $)$ ): $\delta 3.75$ (s, 12H), 3.48 (s, 4H) ppm.

${ }^{13}$ C NMR (151 MHz, CDCl 3$): \delta 171.4,52.7,40.3$ ppm.

HRMS (ESI-TOF): calc'd for $\mathrm{C}_{12} \mathrm{H}_{17} \mathrm{O}_{8}[\mathrm{M}+\mathrm{H}]^{+}:$289.0923, found: 289.0928 .

TLC: $\mathrm{R}_{f}=0.30(2: 1$ hexanes/EtOAc). 
Graphical Supporting Information for the Synthesis of Compounds 8 and 9
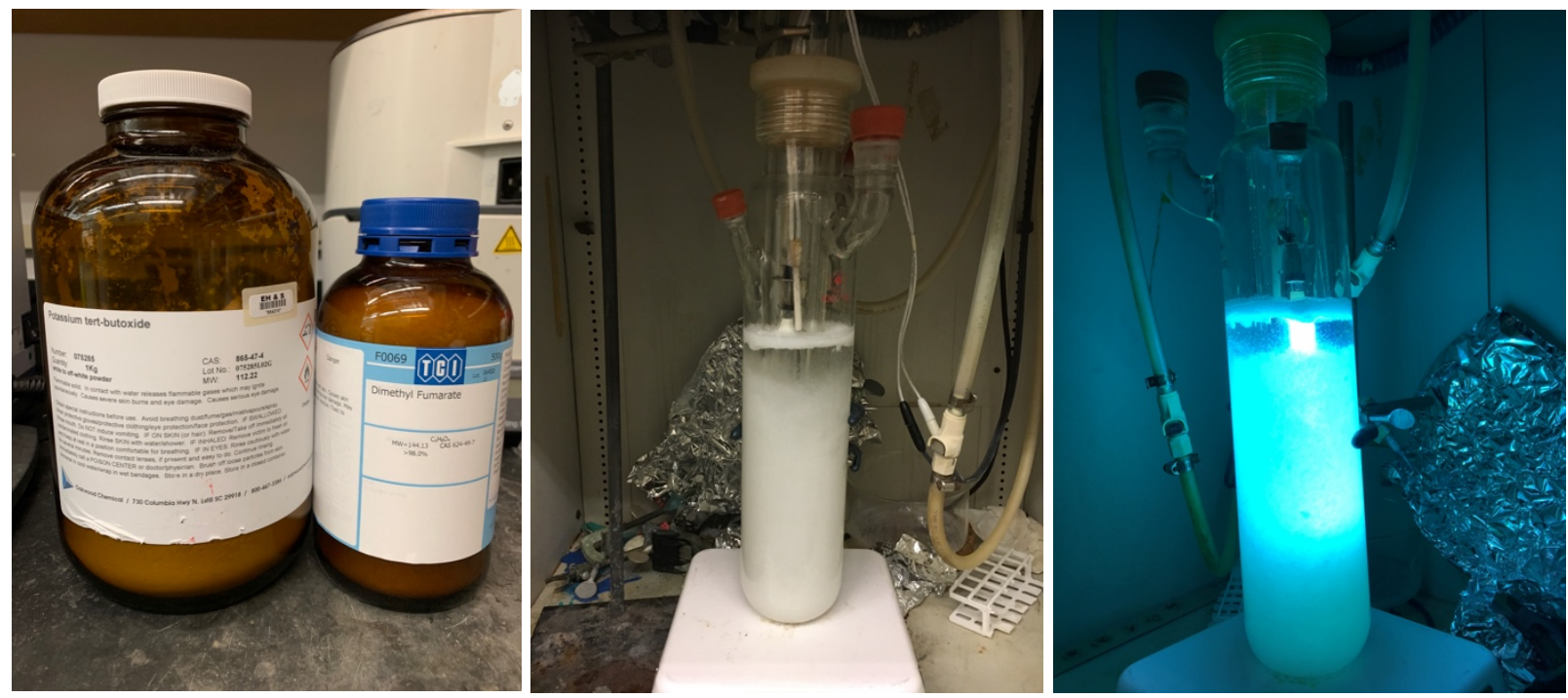

(Left) Reagents used for these reactions. From left to right: $t$-BuOK and Dimethyl Fumarate. (Center) Dimethyl fumarate dispersed in $\mathrm{H}_{2} \mathrm{O}$ in a $1 \mathrm{~L}$ photochemical reaction vessel with quartz immersion well (containing a high pressure mercury lamp) submerged into the solution. No precaution was taken to exclude air from reactor. (Right) Irradiation of solution while stirring vigorously.
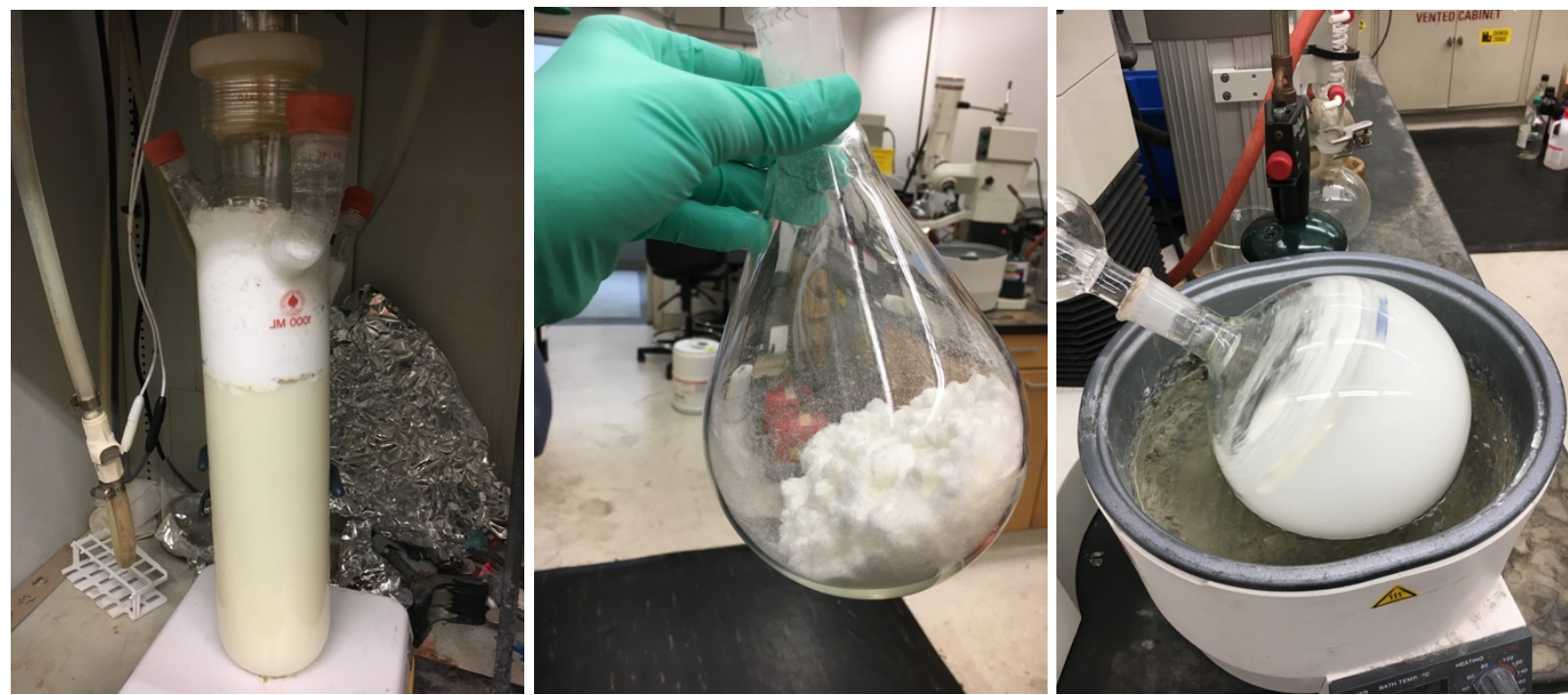

(Left) Appearance of reaction after dimerization was completed. (Center) Compound 8 after filtration. (Right) Azeotrop of $\mathbf{8}$ with Toluene. 

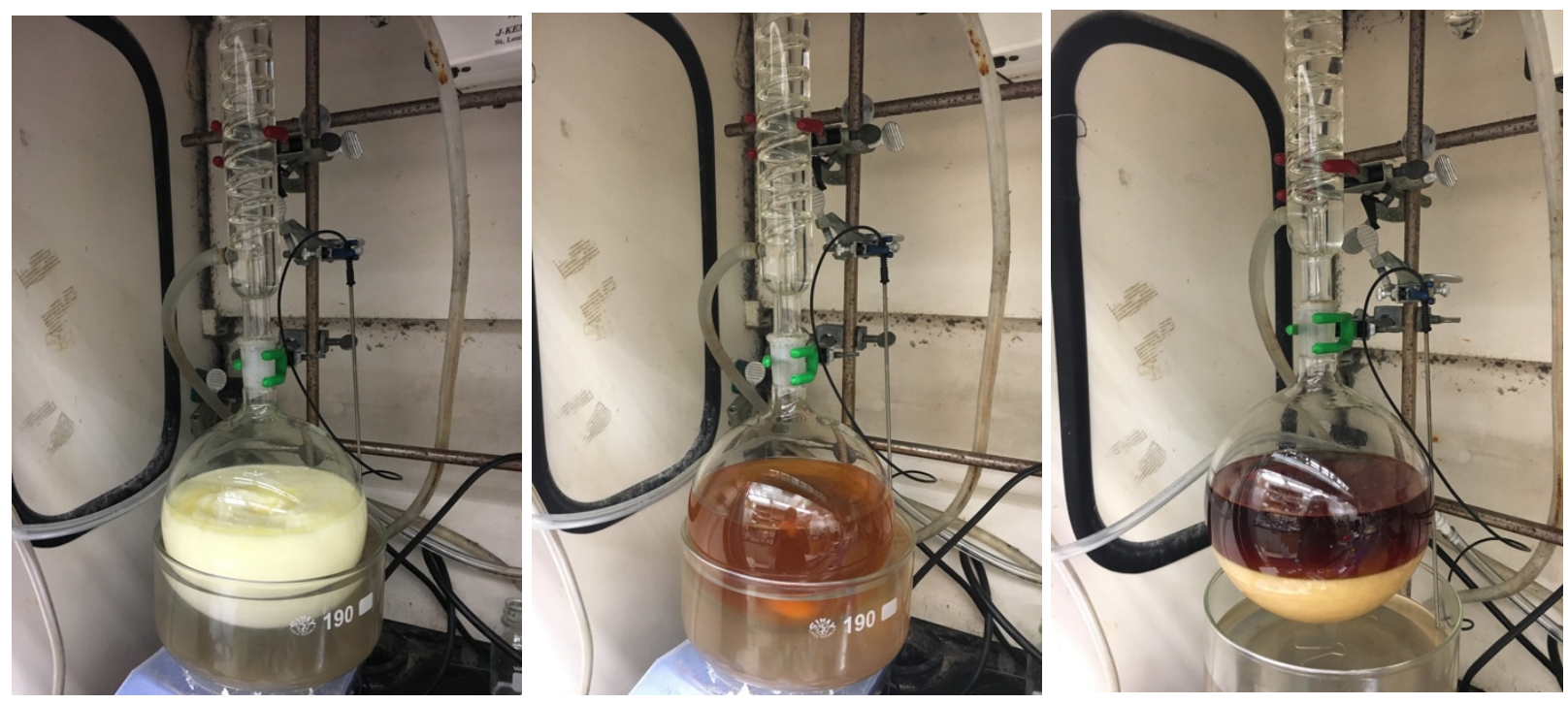

(Left) Dispersion of 8 and $t$-BuOK in $\mathrm{MeOH}$ before heat has been applied. (Center) Reaction mixture after reaching $80^{\circ} \mathrm{C}$. (Right) Reaction mixture after full consumption of 8 and cooling to room temperature. Desired compound 9 has already begun to crash out of the solution.
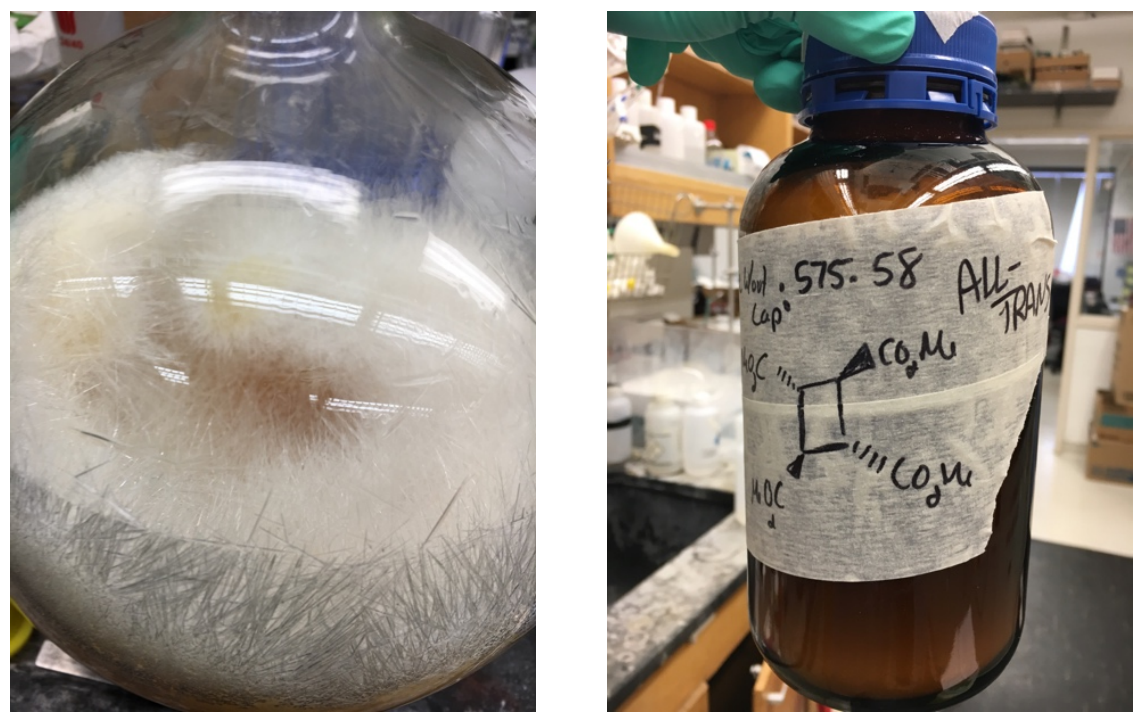

(Left). Crystalization of 9 after cooling solution to $-20^{\circ} \mathrm{C}$. (Right) Isolated product 9. 


\section{Compound 3}

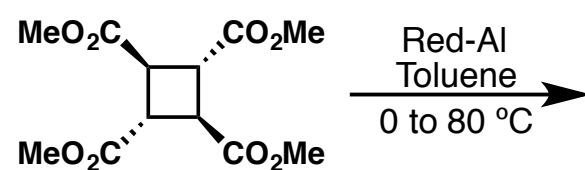

9

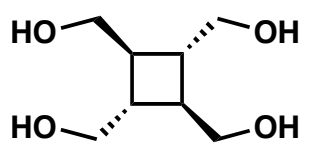

(not purified)

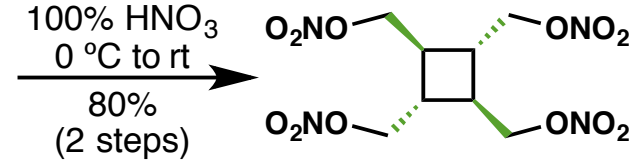

3

Caution! Although we did not experience any problems in performing the reaction described in this paper, proper laboratory precautions should be taken. Laboratories and personnel should be properly grounded, and safety equipment such as heavy Kevlar/steel gloves, reinforced Kevlar coat, ballistic face shield, ear plugs, and blast shields are necessary.

Compound $\mathbf{3}$ was prepared following the same procedure as that used to synthesize compound $\mathbf{2}$, with a $60 \mathrm{wt} . \%$ solution of Red-Al in toluene (17.5 g, $16.9 \mathrm{~mL}, 52.1 \mathrm{mmol}, 5.00$ equiv.), tetraester 9 (3 g, $10.4 \mathrm{mmol}, 1.00$ equiv.), and toluene (50 mL). After workup, $2.89 \mathrm{~g}$ of the presumed tetrol contaminated with aluminum salts was obtained and subjected to the same nitration conditions as that to give compound 2 (using $30 \mathrm{~mL} 100 \% \mathrm{HNO}_{3}$ ) without further purification. Workup and recrystallization from hot isopropanol afforded tetranitrate 3 (2.97 g, 80\%) as a white solid.

Physical State: white solid.

m.p.: $47.5-49.7^{\circ} \mathrm{C}$.

T $_{\text {dec }}$ (onset): $199.7^{\circ} \mathrm{C}$.

$\mathbf{T}_{\text {peak: }}: 223.8^{\circ} \mathrm{C}$.

IR (neat): $\tilde{v}=2964.39(\mathrm{w}), 2886.45(\mathrm{w}), 1611.76(\mathrm{~s}), 1267.36(\mathrm{~s}) \mathrm{cm}^{-1}$.

${ }^{1}$ H NMR (400 MHz, acetone-d $)$ ): $\delta 4.70$ (s, $\left.8 \mathrm{H}\right), 2.61$ (s, 4H) ppm.

${ }^{13}$ C NMR (101 MHz, acetone-d $\left.{ }_{6}\right): \delta 75.0,36.7 \mathrm{ppm}$. 


\section{Compound 11}

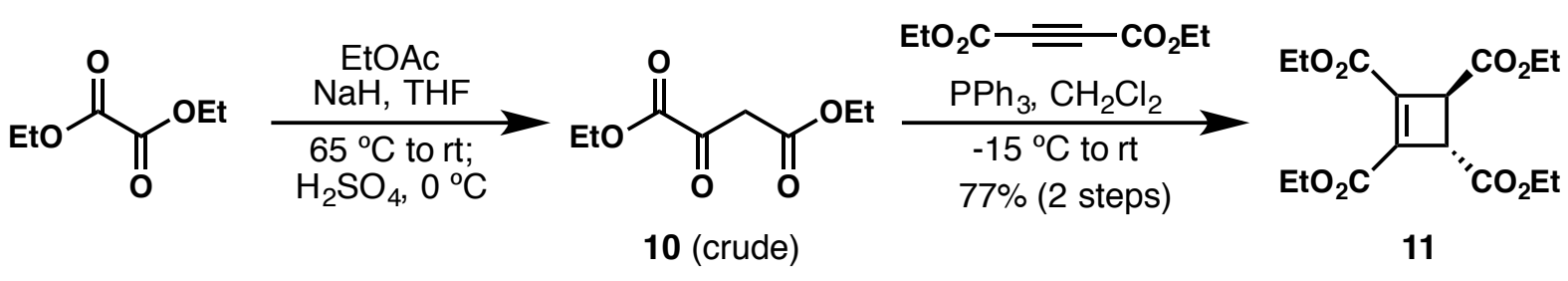

10 was prepared according to a previously reported procedure. ${ }^{3}$ To a flame dried round bottom flask was added $\mathrm{NaH}$ (60\% oil dispersion, $720 \mathrm{mg}, 18 \mathrm{mmol}, 1.2$ equiv.), which was then placed under argon and dispersed in THF $(30 \mathrm{~mL})$. The reaction was then heated to $65{ }^{\circ} \mathrm{C}$ and diethyl oxylate ( $2.0 \mathrm{~mL}, 15 \mathrm{mmol}, 1$ equiv.) was added dropwise, followed by EtOAc (dropwise, $1.5 \mathrm{~mL}$, 15 mmol, 1 equiv.). The reaction was stirred at $65^{\circ} \mathrm{C}$ for 1.5 hours before cooling to room temperature and stirring for an additional 1 hour. The reaction was cooled to $0{ }^{\circ} \mathrm{C}$ and quenched by the careful addition of concentrated sulfuric acid until $\mathrm{pH} 3$ was reached. The suspension was filtered through a pad of Celite and concentrated under reduced pressure. The resulting oil was then diluted with EtOAc, washed with $\mathrm{H}_{2} \mathrm{O}(3 \mathrm{x})$, dried with $\mathrm{Na}_{2} \mathrm{SO}_{4}$, filtered and concentrated to give $2.811 \mathrm{~g} \mathrm{(99 \% )} \mathrm{of} \mathbf{1 0}$ as a red oil which was used without any additional purification.

Cyclization was performed according to a reported procedure. ${ }^{4} \mathbf{1 0}(1.76 \mathrm{~g}, 9.35 \mathrm{mmol}, 1$ equiv.) and triphenylphosphine ( $2.45 \mathrm{~g}, 9.35 \mathrm{mmol}, 1$ equiv.) were added to a round bottom flask, placed under argon, and dissolved in anhydrous DCM $(19 \mathrm{~mL})$. The reaction mixture was then cooled to $-15^{\circ} \mathrm{C}$ and a solution of diethyl acetylenedicarboxylate $(1.5 \mathrm{~mL}, 9.35 \mathrm{mmol}, 1$ equiv.) in DCM $(9.5 \mathrm{~mL})$ was added dropwise. The reaction was then allowed to gradually warm to room temperature and stirred for an additional 2 days until complete consumption of the starting material was observed. The reaction was concentrated and purified by column chromatography (silica, 97:3 hexanes/EtOAc to 23:2 hexanes:EtOAc) to afford compound $\mathbf{1 1}$ (2.46 g, 77\%, 2 steps).

Physical State: pale yellow oil.

${ }^{1}$ H NMR (600 MHz, CDCl $): \delta 4.27$ (ttd, $\left.J=10.5,6.9,6.4,3.2 \mathrm{~Hz}, 4 \mathrm{H}\right), 4.20$ (q, $J=7.3 \mathrm{~Hz}, 4 \mathrm{H}$ ), 3.81 (s, 2H), 1.31 (t, $J=7.1 \mathrm{~Hz}, 6 \mathrm{H}), 1.27$ (t, $J=7.3 \mathrm{~Hz}, 6 \mathrm{H}) \mathrm{ppm}$.

${ }^{13}$ C NMR (151 MHz, $\mathbf{C D C l}_{3}$ ): $\delta 169.1,159.8,141.5,61.8,61.7,46.0,14.2,14.2 \mathrm{ppm}$.

HRMS (ESI-TOF): calc'd for $\mathrm{C}_{16} \mathrm{H}_{23} \mathrm{O}_{8}[\mathrm{M}+\mathrm{H}]^{+}: 343.1393$, found: 343.1398 .

TLC: $\mathrm{R}_{f}=0.25$ (4:1 hexanes/EtOAc). 


\section{Compound 12}

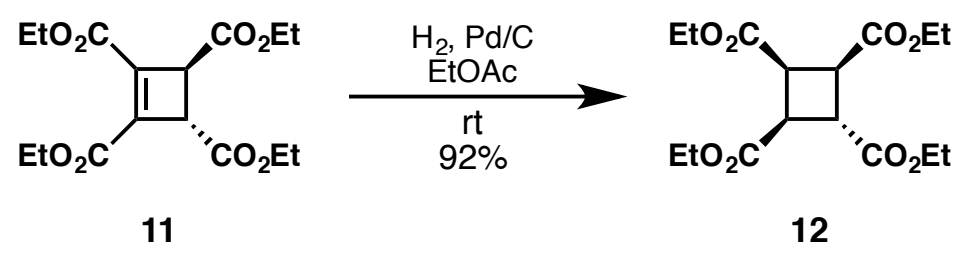

Compound 11 (1.0 g, 2.92 mmol, 1 equiv.) and 10\% Pd/C (155.4 mg, $0.146 \mathrm{mmol}, 5 \mathrm{~mol} \%$ ) were added to a round bottom flask and dissolved in EtOAc $(29 \mathrm{~mL})$. The solution was sparged with Argon for 20 minutes before exchanging for a balloon of $\mathrm{H}_{2}$. The reaction was then stirred at room temperature under $\mathrm{H}_{2}$ atmosphere overnight. Once starting material was fully consumed (monitored by ${ }^{1} \mathrm{H}$ NMR), the reaction was sparged with argon then filtered through a plug of Celite. After concentration, the filtrate was passed through a flash column (silica, 7:3 hexanes/EtOAc) to remove small amounts of residual Pd and afford $922.4 \mathrm{mg}(92 \%)$ of compound 12.

Physical State: pale yellow oil.

${ }^{1}$ H NMR (600 MHz, CDCl 3$): \delta 4.20(\mathrm{qd}, J=7.1,1.6 \mathrm{~Hz}, 2 \mathrm{H}), 4.17-4.10(\mathrm{~m}, 6 \mathrm{H}), 4.07$ (t, $J=$ $9.9 \mathrm{~Hz}, 1 \mathrm{H}), 3.60(\mathrm{t}, J=9.1 \mathrm{~Hz}, 1 \mathrm{H}), 3.46(\mathrm{td}, J=9.6,1.7 \mathrm{~Hz}, 2 \mathrm{H}), 1.28(\mathrm{td}, J=7.2,1.6 \mathrm{~Hz}, 3 \mathrm{H})$, $1.24(\mathrm{dtd}, J=11.7,7.1,1.6 \mathrm{~Hz}, 9 \mathrm{H}) \mathrm{ppm}$.

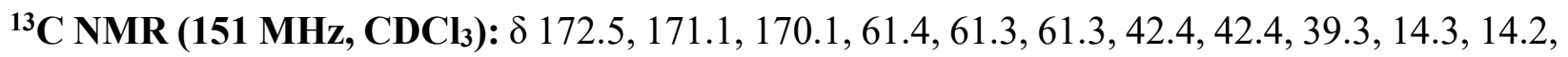
$14.2 \mathrm{ppm}$.

HRMS (ESI-TOF): calc'd for $\mathrm{C}_{16} \mathrm{H}_{25} \mathrm{O}_{8}[\mathrm{M}+\mathrm{H}]^{+}:$345.1549, found: 345.1545 .

TLC: $\mathrm{R}_{f}=0.45$ (2:1 hexanes/EtOAc). 


\section{Compound 4}

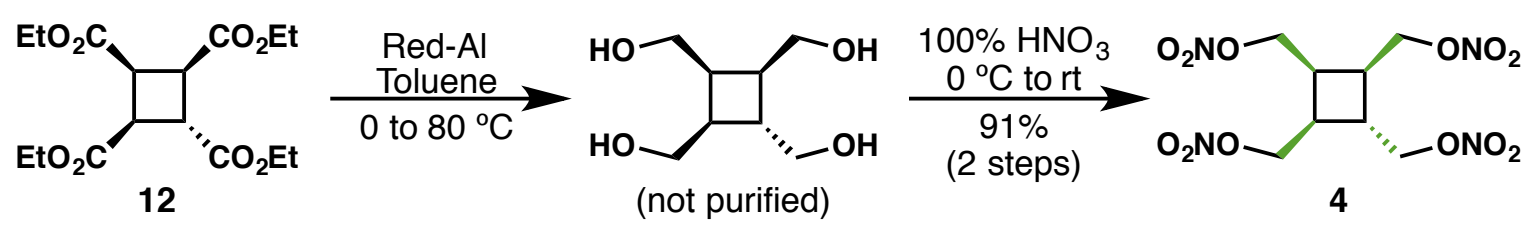

Caution! Although we did not experience any problems in performing the reaction described in this paper, proper laboratory precautions should be taken. Laboratories and personnel should be properly grounded, and safety equipment such as heavy Kevlar/steel gloves, reinforced Kevlar coat, ballistic face shield, ear plugs, and blast shields are necessary.

Compound 4 was prepared following the same procedure as that used to synthesize compound $\mathbf{2}$, with a 60 wt.\% solution of Red-Al in toluene (9.79 g, $9.45 \mathrm{~mL}, 29.1 \mathrm{mmol}, 5.00$ equiv.), tetraester 12 ( $2 \mathrm{~g}, 5.81 \mathrm{mmol}, 1.00$ equiv.), and toluene ( $25 \mathrm{~mL})$. After workup, $2.44 \mathrm{~g}$ of the presumed tetrol contaminated with aluminum salts was obtained and subjected to the same nitration conditions (using $20 \mathrm{~mL} \mathrm{100 \%} \mathrm{HNO}_{3}$ ) as that to make compound 2 without further purification. The nitration was quenched by pouring the reaction mixture onto crushed ice and subsequently stirring for 2 hours, during which time the ice melted. The quenched reaction mixture was transferred to a separatory funnel and was extracted with $\mathrm{CH}_{2} \mathrm{Cl}_{2}(3 \times 50 \mathrm{~mL})$. The combined organic extracts were washed with a saturated solution of $\mathrm{NaHCO}_{3}(50 \mathrm{~mL})$, dried over magnesium sulfate, and filtered. Evaporation of the solvent in a well-ventilated fume hood afforded tetranitrate 4 (1.88 g, 91\%) as a viscous light-yellow liquid.

Physical State: viscous light-yellow liquid.

$\mathbf{T}_{\text {dec }}$ (onset): $186.8^{\circ} \mathrm{C}$.

$\mathbf{T}_{\text {peak }}: 214.6^{\circ} \mathrm{C}$.

IR (neat): $\tilde{v}=2964.82(\mathrm{w}), 2987.15(\mathrm{w}), 1617.21(\mathrm{~s}), 1270.62(\mathrm{~s}) \mathrm{cm}^{-1}$.

${ }^{1}$ H NMR (400 MHz, acetone-d $): \delta 5.00(\mathrm{~d}, J=8 \mathrm{~Hz}, 2 \mathrm{H}), 4.81-4.71(\mathrm{~m}, 6 \mathrm{H}), 3.11$ (q, $J=8 \mathrm{~Hz}$, $1 \mathrm{H}), 3.00-2.88(\mathrm{~m}, 3 \mathrm{H}) \mathrm{ppm}$.

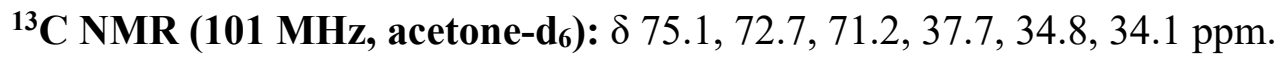




\section{Compound SI-2}

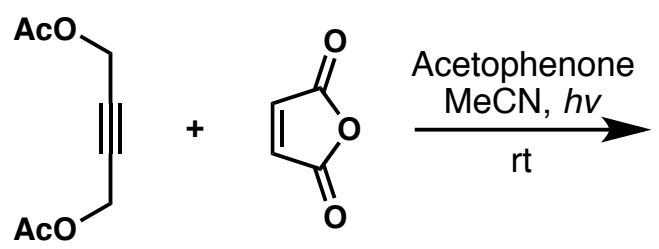

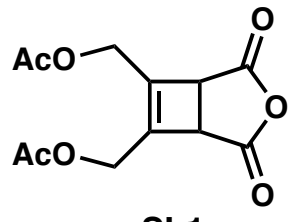

SI-1

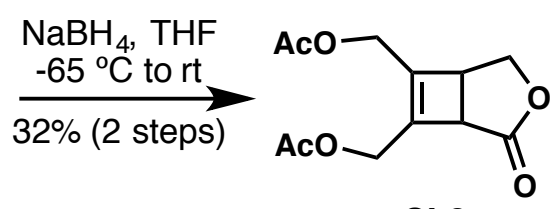

SI-2

Maleic anhydride (1.96 g, 20 mmol, 1 equiv.), 2-butyne-1,4-diol diacetate (4.1 g, 24 mmol, 1.2 equiv.), and acetophenone $(0.47 \mathrm{~mL}, 4 \mathrm{mmol}, 0.2$ equiv.) were equally separated into 4 separate pyrex culture tubes, dissolved in $\mathrm{MeCN}$ (4x 25mL) and sparged with Argon for 15 minutes. The reaction mixtures were then irradiated with a mercury lamp while stirring vigorously at room temperature. After 9 days, full consumption of maleic anhydride was observed by ${ }^{1} \mathrm{H}$ NMR. All 4 reactions were then combined and concentrated under reduced pressure to give compound SI-1 which was then subsequently used without any additional purification.

$\mathrm{NaBH}_{4}$ (780 mg, $20.6 \mathrm{mmol}, 1.03$ equiv.) was added to a flame dried round bottom flask, dispersed in THF (10 mL), and cooled to $-65^{\circ} \mathrm{C}$. A solution of SI-1 in THF $(20 \mathrm{~mL})$ was then added dropwise. The reaction was allowed to gradually warm to room temperature and upon full consumption of SI-1 (monitered by ${ }^{1} \mathrm{H}$ NMR), the reaction was quenched by the careful addition of $1 \mathrm{M} \mathrm{HCl}$. The reaction was then extracted with EtOAc $(3 \mathrm{x})$. The organic layers were then combined, washed with brine, dried with $\mathrm{Na}_{2} \mathrm{SO}_{4}$, filtered, and concentrated. The crude residue was purified twice by column chromatography (silica, 33:17 hexanes/EtOAc) to afford $1.63 \mathrm{~g}(32 \%)$ of the title compound SI-2.

Physical State: pale yellow oil.

${ }^{1}$ H NMR (600 MHz, CDCl 3$): \delta 4.67-4.47(\mathrm{~m}, 4 \mathrm{H}), 4.26(\mathrm{dd}, J=10.0,2.0 \mathrm{~Hz}, 1 \mathrm{H}), 4.19$ (dd, $J$ $=10.1,7.1 \mathrm{~Hz}, 1 \mathrm{H}), 3.46-3.44(\mathrm{~m}, 1 \mathrm{H}), 3.44-3.39(\mathrm{~m}, 1 \mathrm{H}), 1.98(\mathrm{~d}, J=3.3 \mathrm{~Hz}, 6 \mathrm{H})$.

${ }^{13} \mathbf{C}$ NMR (151 MHz, $\left.\mathbf{C D C l}_{3}\right): \delta 173.9,170.4,170.3,142.9,140.7,67.3,58.3,58.2,44.1,39.8$, $20.5,20.5$.

HRMS (ESI-TOF): calc'd for $\mathrm{C}_{12} \mathrm{H}_{15} \mathrm{O}_{6}[\mathrm{M}+\mathrm{H}]^{+}: 255.0869$, found 255.0877.

TLC: $\mathrm{R}_{f}=0.25(1: 1$ hexanes/EtOAc). 


\section{Compound 13}

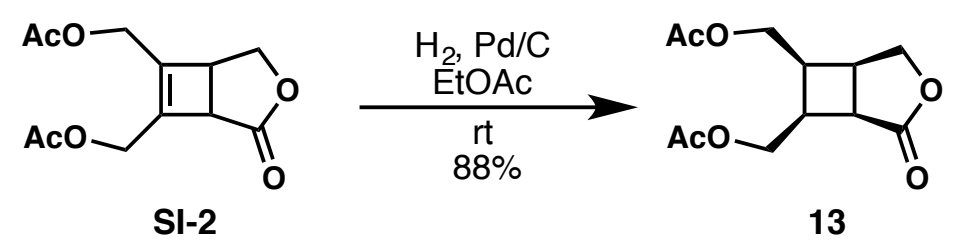

Compound SI-2 (1.59 g, $6.23 \mathrm{mmol}, 1$ equiv.) and 10\% Pd/C (200 mg, $0.187 \mathrm{mmol}, 3 \mathrm{~mol} \%$ ) were added to a round bottom flask and dissolved in EtOAc $(60 \mathrm{~mL})$. The solution was sparged with Argon for 20 minutes before exchanging for a balloon of $\mathrm{H}_{2}$. The reaction was then stirred at room temperature under $\mathrm{H}_{2}$ atmosphere overnight. Once starting material was fully consumed (monitered by ${ }^{1} \mathrm{H}$ NMR), the reaction was sparged with argon then filtered through a plug of Celite. After concentration, the crude residue was purified by column chromatography (silica, 1.7:1 hexanes/EtOAc) to afford $1.4 \mathrm{~g}(88 \%)$ of the title compound 13.

Physical State: clear crystals.

m.p.: $37-40^{\circ} \mathrm{C}$.

${ }^{1}$ H NMR (600 MHz, $\left.\mathbf{C D C l}_{3}\right): \delta 4.47-4.44(\mathrm{~m}, 1 \mathrm{H}), 4.41(\mathrm{dd}, J=11.8,6.1 \mathrm{~Hz}, 1 \mathrm{H}), 4.36-4.32$ $(\mathrm{m}, 1 \mathrm{H}), 4.28(\mathrm{dd}, J=11.8,8.9 \mathrm{~Hz}, 1 \mathrm{H}), 4.25(\mathrm{dd}, J=12.1,5.9 \mathrm{~Hz}, 1 \mathrm{H}), 4.18(\mathrm{dd}, J=12.0,7.0$ $\mathrm{Hz}, 1 \mathrm{H}), 3.31-3.26(\mathrm{~m}, 2 \mathrm{H}), 3.26-3.19(\mathrm{~m}, 1 \mathrm{H}), 3.11-3.04(\mathrm{~m}, 1 \mathrm{H}), 2.05(\mathrm{~s}, 3 \mathrm{H}), 2.05(\mathrm{~s}, 3 \mathrm{H})$ ppm.

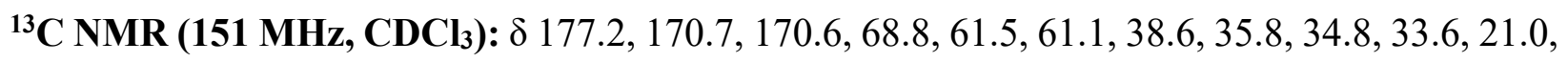
$20.9 \mathrm{ppm}$.

HRMS (ESI-TOF): calc'd for $\mathrm{C}_{12} \mathrm{H}_{17} \mathrm{O}_{6}[\mathrm{M}+\mathrm{H}]^{+}:$257.1025, found: 257.1022 .

TLC: $\mathrm{R}_{f}=0.25(1: 1$ hexanes/EtOAc). 


\section{Compound 5}

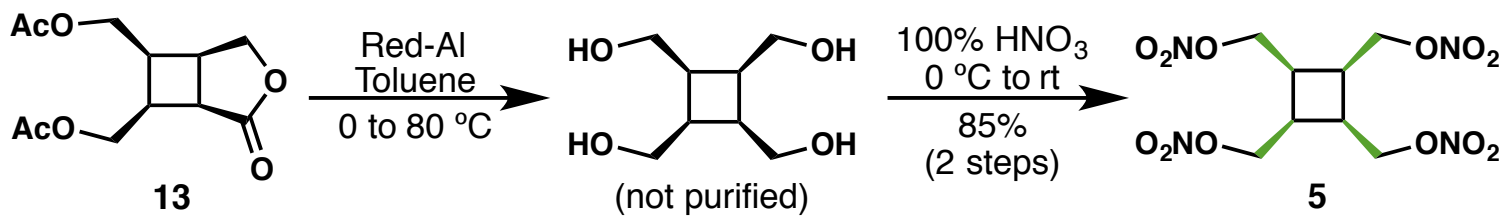

Caution! Although we did not experience any problems in performing the reaction described in this paper, proper laboratory precautions should be taken. Laboratories and personnel should be properly grounded, and safety equipment such as heavy Kevlar/steel gloves, reinforced Kevlar coat, ballistic face shield, ear plugs, and blast shields are necessary.

Compound $\mathbf{5}$ was prepared following the same procedure as that used to synthesize compound $\mathbf{2}$, with a 60 wt.\% solution of Red-Al in toluene ( $6.58 \mathrm{~g}, 6.35 \mathrm{~mL}, 19.5 \mathrm{mmol}, 5.00$ equiv.), 13 ( $1 \mathrm{~g}$, $3.90 \mathrm{mmol}, 1.00$ equiv.), and toluene $(25 \mathrm{~mL})$. After workup, $2.80 \mathrm{~g}$ of the presumed tetrol contaminated with aluminum salts was obtained and subjected to the same nitration conditions (using $20 \mathrm{~mL} \mathrm{100 \%} \mathrm{HNO}_{3}$ ) as that to make compound 2 without further purification. Workup and recrystallization from hot isopropanol afforded tetranitrate $\mathbf{5}(1.18 \mathrm{~g}, 85 \%)$ as a white solid.

Physical State: white solid.

m.p.: $100.8-102.7^{\circ} \mathrm{C}$.

T $_{\text {dec }}$ (onset): $194.3^{\circ} \mathrm{C}$.

Tpeak: $210.3^{\circ} \mathrm{C}$.

IR (neat): $\tilde{v}=3001.85$ (w) 2973.70 (w), 2891.13 (w), 1646.65 (m), 1613.96 (s), 1479.41 (m), $1284.77(\mathrm{~s}), 1270.28(\mathrm{~s}) \mathrm{cm}^{-1}$.

${ }^{1}$ H NMR (400 MHz, acetone-d $)$ ): $\delta 4.96$ (s, $\left.8 \mathrm{H}\right), 3.31$ (s, 4H) ppm.

${ }^{13}$ C NMR (101 MHz, acetone-d $\left.{ }_{6}\right): \delta 71.5,34.3 \mathrm{ppm}$. 


\section{Compound 14}

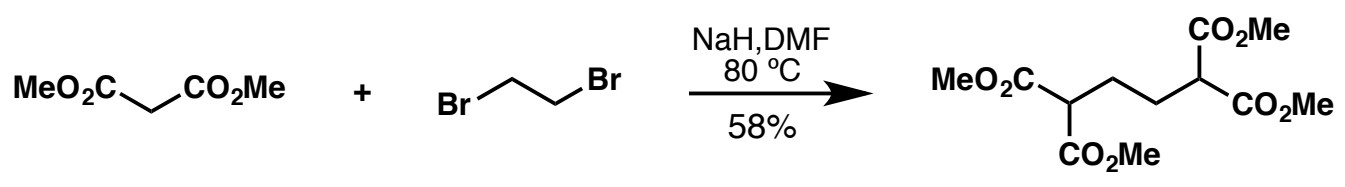

14

$\mathrm{NaH}$ (60\% oil dispersion, $4.8 \mathrm{~g}, 120 \mathrm{mmol}, 4$ equiv.) was added to a flame dried 3 neck round bottom flask, placed under argon, dispersed in DMF $(30 \mathrm{~mL})$ and heated to $80{ }^{\circ} \mathrm{C}$. Dimethyl malonate (17.1 mL, $150 \mathrm{mmol}, 5$ equiv.) was then added slowly until no more gas evolution was observed. A solution of dibromoethane $(2.6 \mathrm{~mL}, 30 \mathrm{mmol}, 1$ equiv.) in DMF $(30 \mathrm{~mL})$ was then added dropwise via an addition funnel over 1.5 hours. The reaction was allowed to stir at $80{ }^{\circ} \mathrm{C}$ for 24 hours before cooling to room temperature and carefully being quenched with $0.5 \mathrm{M} \mathrm{HCl}$. The reaction was then extracted with EtOAc $(3 \mathrm{x})$ and the organic layers were combined, dried with $\mathrm{Na}_{2} \mathrm{SO}_{4}$, filtered, and concentrated. The crude filtrate was then purified by column chromatography (silica, 17:3 hexanes/EtOAc to $4: 1$ hexanes/EtOAc) to afford the desired product that was recrystallized from $\mathrm{MeOH}$ to give $5.05 \mathrm{~g}(58 \%)$ of the title compound 14 .

Physical State: white solid.

m.p.: $58-62^{\circ} \mathrm{C}$.

${ }^{1}$ H NMR (600 MHz, CDCl 3$): \delta 3.74(\mathrm{~s}, 12 \mathrm{H}), 3.41-3.35(\mathrm{~m}, 2 \mathrm{H}), 1.93(\mathrm{~d}, J=3.6 \mathrm{~Hz}, 4 \mathrm{H}) \mathrm{ppm}$.

${ }^{13}$ C NMR (151 MHz, $\left.\mathbf{C D C l}_{3}\right): \delta 169.4,52.8,51.4,26.6$ ppm.

HRMS (ESI-TOF): calc'd for $\mathrm{C}_{12} \mathrm{H}_{19} \mathrm{O}_{8}[\mathrm{M}+\mathrm{H}]^{+}:$: 291.1080, found: 291.1082 .

TLC: $\mathrm{R}_{f}=0.27(2: 1$ hexanes/EtOAc). 


\section{Compound 15}

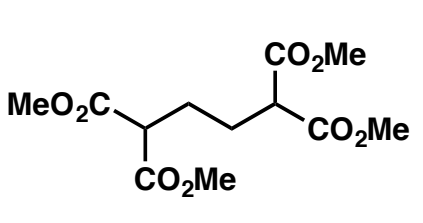

14

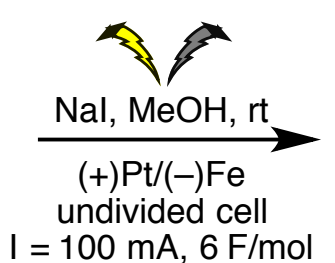

$92 \%$

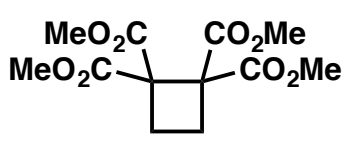

15

The following was modified from a previously reported procedure. ${ }^{5}$ To a $20 \mathrm{~mL}$ ElectraSyn Vial was added compound 14 (1.5 g, 5.17 mmol, 1 equiv.) and $\mathrm{NaI}$ (519 mg, $3.46 \mathrm{mmol}, 0.67$ equiv.). The ElectraSyn vial cap, equipped with anode $(\mathrm{Pt})$ and cathode $(\mathrm{Fe})$, was inserted into the mixture. The vial was then evacuated and backfilled with Argon from a balloon (3x) and dissolved in anhydrous $\mathrm{MeOH}(17 \mathrm{~mL})$. The reaction mixture was electrolyzed under a constant current of 100 $\mathrm{mA}$ until $6 \mathrm{~F} / \mathrm{mol}$ had been passed through the solution. The reaction was then diluted with EtOAc and washed with sat. $\mathrm{Na}_{2} \mathrm{~S}_{2} \mathrm{O}_{3}(1 \mathrm{x}), \mathrm{H}_{2} \mathrm{O}(3 \mathrm{x})$ and brine (1x). The organic layers were then dried with $\mathrm{Na}_{2} \mathrm{SO}_{4}$, filtered, concentrated, and purified by flash column chromatography (silica, 1:1 hexanes/EtOAc) to afford $1.364 \mathrm{~g}(92 \%)$ of the title compound $\mathbf{1 5}$.

Physical State: white solid.

m.p.: $65-68^{\circ} \mathrm{C}$.

${ }^{1}$ H NMR (600 MHz, CDCl $)$ ): $\delta 3.76$ (s, 12H), 2.60 (s, 3H) ppm.

${ }^{13}$ C NMR (151 MHz, CDCl 3$): ~ \delta 170.3,58.6,53.1,26.0$ ppm.

HRMS (ESI-TOF): calc'd for $\mathrm{C}_{12} \mathrm{H}_{17} \mathrm{O}_{8}[\mathrm{M}+\mathrm{H}]^{+}: 289.0923$, found: 289.0928 .

TLC: $\mathrm{R}_{f}=0.27(2: 1$ hexanes/EtOAc). 
For detailed graphical information of the set-up and use of ElectraSyn see Reference 6.
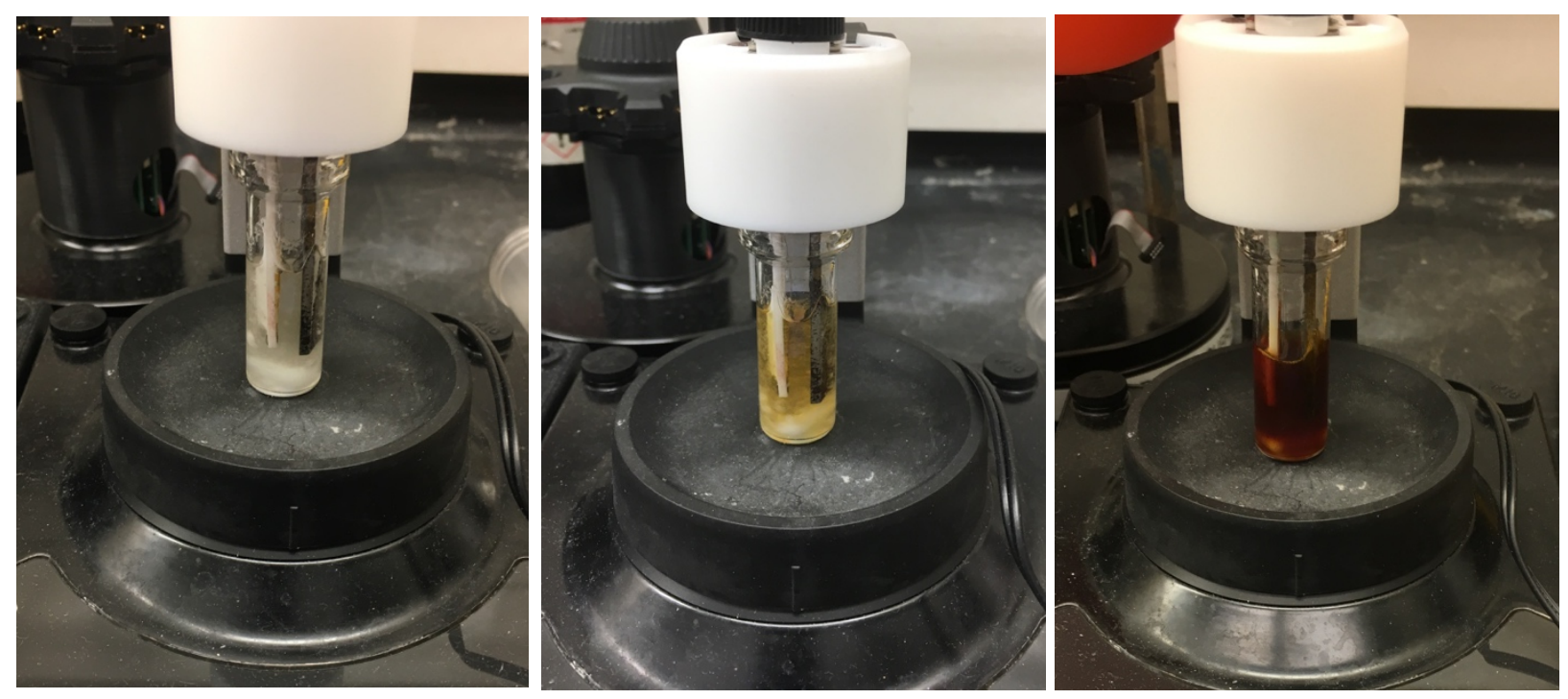

(Left) Reaction vial containing 14, NaI, and $\mathrm{MeOH}$ before beginning electrolysis. Compound 14 is not dissolved at this point. (Center) Reaction mixure after electrolysis began. Note that a color change can already be observed as $\mathrm{I}_{2}$ is generated. (Right) Reaction mixture after completion of electrolysis. 


\section{Compound 6}

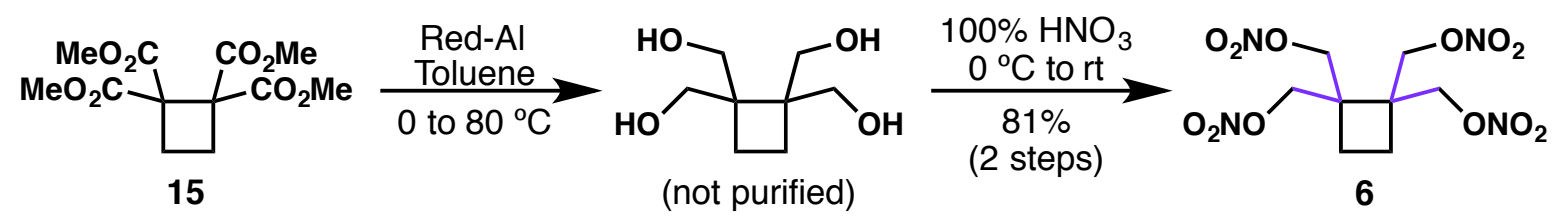

Caution! Although we did not experience any problems in performing the reaction described in this paper, proper laboratory precautions should be taken. Laboratories and personnel should be properly grounded, and safety equipment such as heavy Kevlar/steel gloves, reinforced Kevlar coat, ballistic face shield, ear plugs, and blast shields are necessary.

Compound $\mathbf{6}$ was prepared following the same procedure as that used to synthesize compound $\mathbf{2}$, with a 60 wt.\% solution of Red-Al in toluene (5.84 g, $5.64 \mathrm{~mL}, 17.4 \mathrm{mmol}, 5.00$ equiv.), 15 (1 g, $3.47 \mathrm{mmol}, 1.00$ equiv.), and toluene $(25 \mathrm{~mL})$. After workup, $2.93 \mathrm{~g}$ of the presumed tetrol contaminated with aluminum salts was obtained and subjected to the same nitration conditions

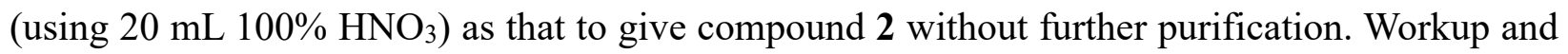
recrystallization from hot isopropanol afforded tetranitrate $\mathbf{6}(1.00 \mathrm{~g}, 81 \%)$ as a white solid.

Physical State: white solid.

m.p.: $85.9-86.7^{\circ} \mathrm{C}$.

T $_{\text {dec }}$ (onset): $192.8^{\circ} \mathrm{C}$.

T $_{\text {peak: }}: 218.9^{\circ} \mathrm{C}$.

IR (neat): $\tilde{v}=3001.38$ (w), $2975.13(\mathrm{w}), 2891.32$ (w), $1614.62(\mathrm{~s}), 1472.51(\mathrm{w}), 1270.24(\mathrm{~s})$ $\mathrm{cm}^{-1}$.

${ }^{1}$ H NMR (400 MHz, acetone-d 6$): \delta 4.87\left(\mathrm{AB}_{\mathrm{q}}, J=12 \mathrm{~Hz}, 8 \mathrm{H}\right), 2.23$ (s, 4H) ppm.

${ }^{13}$ C NMR (101 MHz, acetone-d $)$ ): $\delta$ 72.8, 44.1, 23.3 ppm. 


\section{Compound 17}

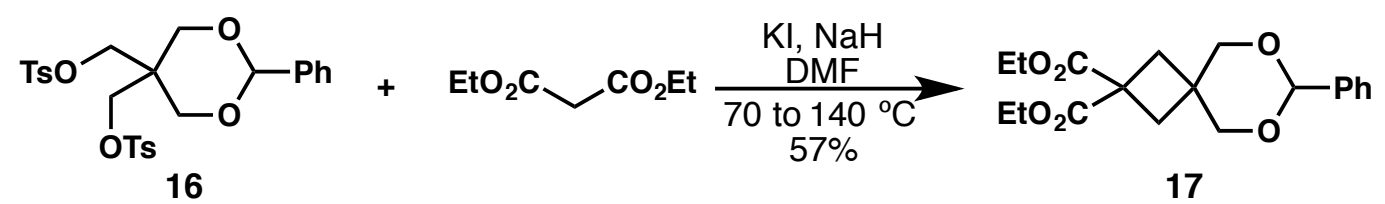

$\mathrm{NaH}$ (60\% oil dispersion, $1.32 \mathrm{~g}, 33.1 \mathrm{mmol}, 2$ equiv.) was added to a flame dried 3 neck round bottom flask, placed under argon, dispersed in DMF $(33 \mathrm{~mL})$ and heated to $70{ }^{\circ} \mathrm{C}$. Diethyl malonate (5.13 mL, $33.8 \mathrm{mmol}, 2.04$ equiv.) was then added dropwise until no more gas evolution was observed. The reaction was stirred at $70{ }^{\circ} \mathrm{C}$ for 30 minutes, then 16 (8.82 g, $16.55 \mathrm{mmol}, 1$ equiv., prepared in 2 steps from pentaerythritol $\left.{ }^{7}\right)$ and $\mathrm{KI}(274 \mathrm{mg}, 1.66 \mathrm{mmol}, 0.1$ equiv.) were added in one portion and the reaction was stirred at $140^{\circ} \mathrm{C}$ overnight. The reaction was then allowed to cool to room temperature and quenched by the careful addition of saturated $\mathrm{NH}_{4} \mathrm{Cl}$. The aqueous phase was extracted with EtOAc $(4 x)$. The organic layers were then combined, washed with $\mathrm{H}_{2} \mathrm{O}(2 \mathrm{x})$, dried over $\mathrm{Na}_{2} \mathrm{SO}_{4}$, filtered, and concentrated. Crude filtrate was purified by column chromatography (silica, 23:2 hexanes/EtOAc) to afford $3.29 \mathrm{~g}(57 \%)$ of the title compound 17.

Physical State: white solid.

m.p.: $75-77^{\circ} \mathrm{C}$.

${ }^{1}$ H NMR (600 MHz, $\left.\mathbf{C D C l}_{3}\right): \delta 7.46(\mathrm{~d}, J=7.6 \mathrm{~Hz}, 2 \mathrm{H}), 7.38-7.30(\mathrm{~m}, 3 \mathrm{H}), 5.41(\mathrm{~s}, 1 \mathrm{H}), 4.22$ (q, $J=7.1 \mathrm{~Hz}, 4 \mathrm{H}), 4.15(\mathrm{~d}, J=11.1 \mathrm{~Hz}, 2 \mathrm{H}), 3.75(\mathrm{~d}, J=11.0 \mathrm{~Hz}, 2 \mathrm{H}), 2.79(\mathrm{~s}, 2 \mathrm{H}), 2.23(\mathrm{~s}, 2 \mathrm{H})$, $1.26(\mathrm{t}, J=7.2 \mathrm{~Hz}, 6 \mathrm{H}) \mathrm{ppm}$.

${ }^{13}$ C NMR (151 MHz, $\left.\mathbf{C D C l}_{3}\right): \delta 171.8,138.1,129.1,128.4,126.2,101.5,75.4,61.9,47.3,37.7$, $31.8,31.5,14.2 \mathrm{ppm}$.

HRMS (ESI-TOF): calc'd for $\mathrm{C}_{19} \mathrm{H}_{25} \mathrm{O}_{6}[\mathrm{M}+\mathrm{H}]^{+}:$349.1651, found: 349.1655 .

TLC: $\mathrm{R}_{f}=0.60$ (2:1 hexanes/EtOAc). 


\section{Compound 18}

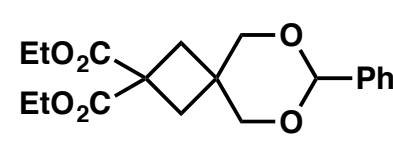

17

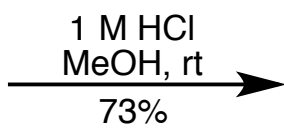

$73 \%$

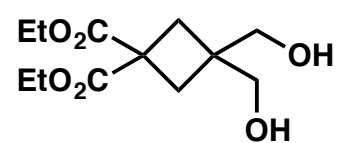

18

Compound 16 (2.0 g, $5.74 \mathrm{mmol})$ was added to a round bottom flask and dissolved in MeOH (140 $\mathrm{mL}) .1 \mathrm{M} \mathrm{HCl}(23 \mathrm{~mL})$ was then added and the reaction was stirred at room temperature overnight. The reaction was concentrated to remove the $\mathrm{MeOH}$ and the remaining aqueous phase was extracted with EtOAc (3x). The organic layers were then combined, dried over $\mathrm{Na}_{2} \mathrm{SO}_{4}$, filtered, and concentrated. Crude filtrate was purified by column chromatography (silica, 3:1 hexanes/EtOAc to 1:3 hexanes:EtOAc) to afford $1.10 \mathrm{~g}(73 \%)$ of the title compound 18 .

Physical State: pale yellow oil.

${ }^{1}$ H NMR (600 MHz, $\left.\mathbf{C D C l}_{3}\right): \delta 4.21$ (q, $\left.J=7.2 \mathrm{~Hz}, 4 \mathrm{H}\right), 3.72(\mathrm{~d}, J=1.9 \mathrm{~Hz}, 4 \mathrm{H}), 2.43$ (d, $J=1.9$ $\mathrm{Hz}, 4 \mathrm{H}), 2.28(\mathrm{bs}, 2 \mathrm{H}), 1.25(\mathrm{t}, J=7.2 \mathrm{~Hz}, 6 \mathrm{H}) \mathrm{ppm}$.

${ }^{13}$ C NMR (151 MHz, $\left.\mathbf{C D C l}_{3}\right): \delta 172.1,68.9,61.9,47.2,38.1,32.8,14.2$ ppm.

HRMS (ESI-TOF): calc'd for $\mathrm{C}_{12} \mathrm{H}_{21} \mathrm{O}_{6}[\mathrm{M}+\mathrm{H}]^{+}: 261.1338$, found: 261.1336.

TLC: $\mathrm{R}_{f}=0.45(1: 3$ hexanes/EtOAc). 


\section{Compound 7}

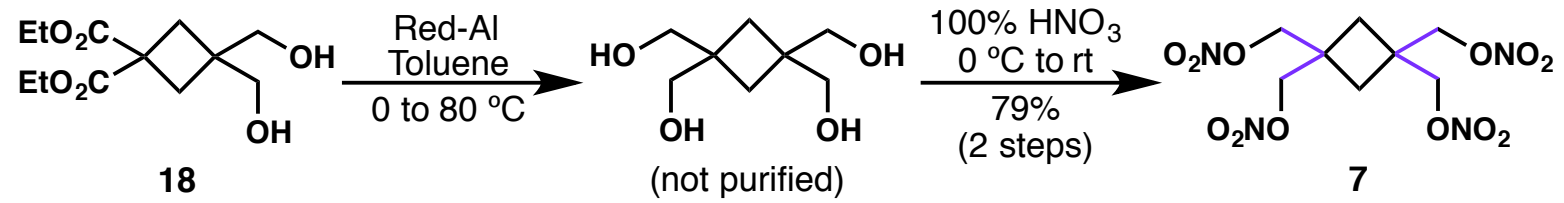

Caution! Although we did not experience any problems in performing the reaction described in this paper, proper laboratory precautions should be taken. Laboratories and personnel should be properly grounded, and safety equipment such as heavy Kevlar/steel gloves, reinforced Kevlar coat, ballistic face shield, ear plugs, and blast shields are necessary.

Compound 7 was prepared following the same procedure as that used to synthesize compound $\mathbf{2}$, with a 60 wt.\% solution of Red-Al in toluene ( $6.48 \mathrm{~g}, 6.25 \mathrm{~mL}, 19.2 \mathrm{mmol}, 5.00$ equiv.), 18 ( $1 \mathrm{~g}$, $3.85 \mathrm{mmol}, 1.00$ equiv.), and toluene $(25 \mathrm{~mL})$. After workup, $2.88 \mathrm{~g}$ of the presumed tetrol contaminated with aluminum salts was obtained and subjected to the same nitration conditions (using $20 \mathrm{~mL} 100 \% \mathrm{HNO}_{3}$ ) as that to give compound 2 without further purification. Workup and recrystallization from hot isopropanol afforded tetranitrate $7(1.08 \mathrm{~g}, 79 \%)$ as a white solid.

Physical State: white solid.

m.p.: $146.9-148.4^{\circ} \mathrm{C}$.

T $_{\text {dec }}$ (onset): $196.2^{\circ} \mathrm{C}$.

T $_{\text {peak: }}: 214.1^{\circ} \mathrm{C}$.

IR (neat): $\tilde{v}=3001.33(\mathrm{w}), 2973.63(\mathrm{w}), 2891.06(\mathrm{w}), 1646.00(\mathrm{~m}), 1616.16(\mathrm{~s}), 1470.24(\mathrm{w})$, $1269.40(\mathrm{~s}) \mathrm{cm}^{-1}$.

${ }^{1}$ H NMR (400 MHz, acetone-d $\left.\mathbf{d}_{6}\right): \delta 4.77$ (s, $\left.8 \mathrm{H}\right), 2.37$ (s, 4H) ppm.

${ }^{13}$ C NMR (101 MHz, acetone-d6): $\delta$ 76.0, 33.9, $31.3 \mathrm{ppm}$. 


\section{X-Ray Crystallographic Data}

\section{General Experimental Details}

Single crystals of compounds (2), (3), (5), (6), and (7) were characterized with a SuperNova, Dualflex, EosS2 diffractometer using a Mo $\mathrm{K} \alpha(\lambda=0.71073 \AA)$ radiation source and an EosS2 charged coupled device (CCD) detector at $298 \mathrm{~K}$. Tables S1, S7, S13, S19, and S25 list the data collection, and structure refinement details for the aformentioned compounds. The diffraction patters were measured using the program CrysAlis ${ }^{\text {Pro }}$. The same program was used to refine the cell dimensions and for data reduction. The structures were solved with SHEL-XT using intrinsic phasing and was refined with SHEL-XL using least squares minimization. Empirical absorption corrections using spherical harmonics, implemented in the Scale3 ABSPACK scaling algorithm, were applied using CrysAlis ${ }^{\text {Pro }}$. The hydrogen atoms were refined using a riding model approximation with parameters having values 1.2 or $1.5 \mathrm{U}_{\text {eq }}$ of the attached $\mathrm{C}$ atoms $[(\mathbf{2}),(\mathbf{3}),(\mathbf{5})]$ or they were refined independently including isotropic displacement parameters $[(6),(7)]$.

The Cambridge Crystallographic Data Centre (CCDC) has assigned crystallographic information file deposition numbers: 1935553, 1935554, 1935555, 1935556, and 1935557 for compounds (2), (3), (5), (6), and (7), respectively. 


\section{Compound 2}

CCDC 1935553

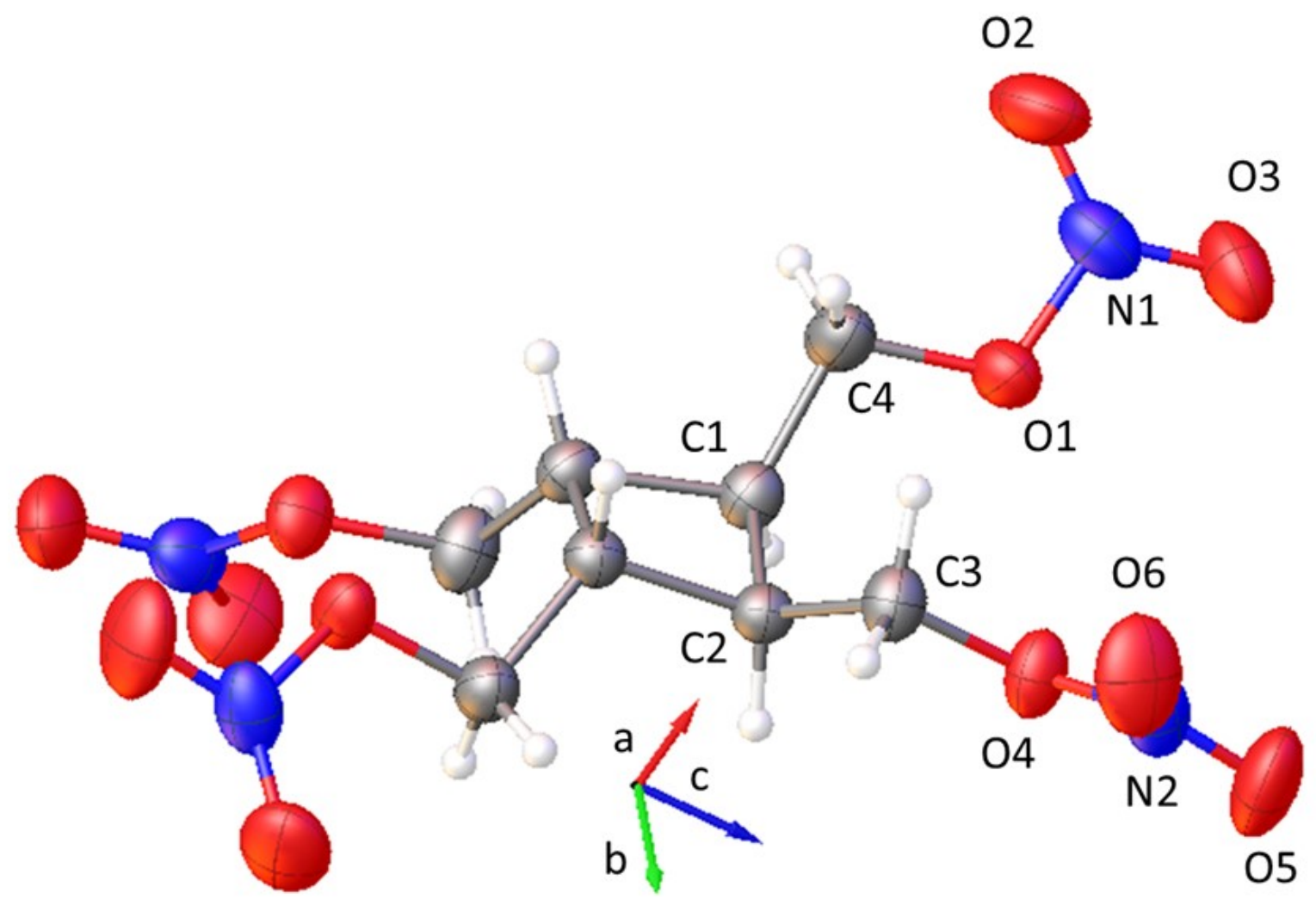

Figure S1. Molecular conformation and atom-numbering scheme for Compound 2. Nonlabeled atoms are generated by inversion $(1-\mathrm{x},-\mathrm{y}, 1 / 2-\mathrm{z})$. Non-hydrogen atoms are shown as $50 \%$ probability displacement ellipsoids. 
Table S1. Crystal data and structure refinement for Compound 2.

\begin{tabular}{|c|c|}
\hline Empirical formula & $\mathrm{C}_{8} \mathrm{H}_{12} \mathrm{~N}_{4} \mathrm{O}_{12}$ \\
\hline Formula weight & 356.22 \\
\hline Temperature/K & $298.00(10)$ \\
\hline Crystal system & orthorhombic \\
\hline Space group & $\mathrm{Pbcn}$ \\
\hline $\mathrm{a} / \AA$ & $7.9408(3)$ \\
\hline $\mathrm{b} / \AA$ & $16.1350(7)$ \\
\hline $\mathrm{c} / \AA$ & $11.2323(4)$ \\
\hline$\alpha /^{\circ}$ & 90 \\
\hline$\beta /{ }^{\circ}$ & 90 \\
\hline$\gamma /{ }^{\circ}$ & 90 \\
\hline Volume $/ \AA^{3}$ & $1439.14(10)$ \\
\hline $\mathrm{Z}$ & 4 \\
\hline$\rho_{\text {calc }} \mathrm{g} / \mathrm{cm}^{3}$ & 1.644 \\
\hline$\mu / \mathrm{mm}^{-1}$ & 0.158 \\
\hline $\mathrm{F}(000)$ & 736.0 \\
\hline Crystal size $/ \mathrm{mm}^{3}$ & $0.35 \times 0.3 \times 0.2$ \\
\hline Radiation & $\operatorname{MoK} \alpha(\lambda=0.71073)$ \\
\hline \multicolumn{2}{|c|}{$2 \Theta$ range for data collection $/{ }^{\circ} 5.05$ to 52.738} \\
\hline Index ranges & $-9 \leq \mathrm{h} \leq 9,-20 \leq \mathrm{k} \leq 19,-14 \leq 1 \leq 12$ \\
\hline Reflections collected & 6369 \\
\hline Independent reflections & $1476\left[\mathrm{R}_{\text {int }}=0.0201, \mathrm{R}_{\text {sigma }}=0.0152\right]$ \\
\hline Data/restraints/parameters & $1476 / 0 / 109$ \\
\hline Goodness-of-fit on $\mathrm{F}^{2}$ & 1.122 \\
\hline Final $R$ indexes $[\mathrm{I}>=2 \sigma(\mathrm{I})]$ & $\mathrm{R}_{1}=0.0412, \mathrm{wR}_{2}=0.1016$ \\
\hline Final $\mathrm{R}$ indexes [all data] & $\mathrm{R}_{1}=0.0475, \mathrm{wR}_{2}=0.1067$ \\
\hline Largest diff. peak/hole / e $\AA$ & $0.29 /-0.27$ \\
\hline
\end{tabular}


Table S2. Fractional Atomic Coordinates $\left(\times 10^{4}\right)$ and Equivalent Isotropic Displacement Parameters $\left(\AA^{2} \times 10^{3}\right)$ for 2 . $U_{\text {eq }}$ is defined as $1 / 3$ of the trace of the orthogonalised $U_{\text {IJ }}$ tensor.

$\begin{array}{lrrrr}\text { Atom } & \boldsymbol{x} & \boldsymbol{y} & \boldsymbol{z} & \mathbf{U}(\mathbf{e q}) \\ \text { C1 } & 5321.7(17) & 5001.4(9) & 3156.9(12) & 32.5(3) \\ \text { C2 } & 5116.2(16) & 5958.0(8) & 3184.0(11) & 28.6(3) \\ \text { C3 } & 6470.1(18) & 6529.0(9) & 3635.9(13) & 36.3(4) \\ \text { C4 } & 7058(2) & 4629(1) & 3234.9(13) & 41.5(4) \\ \text { N1 } & 8948.5(17) & 4196.1(9) & 4757.4(14) & 46.3(4) \\ \text { N2 } & 7221.5(19) & 7131.8(8) & 5496.7(13) & 47.4(4) \\ \text { O1 } & 7512.2(13) & 4645.1(7) & 4487.6(9) & 41.1(3) \\ \text { O2 } & 9697.8(17) & 3872.7(9) & 3954.2(13) & 68.7(4) \\ \text { O3 } & 9269.9(16) & 4193.4(9) & 5806.3(12) & 63.0(4) \\ \text { O4 } & 6380.5(14) & 6494.7(6) & 4924.5(9) & 41.2(3) \\ \text { O5 } & 7028(2) & 7129.4(9) & 6550.5(11) & 72.5(5) \\ \text { O6 } & 8027(2) & 7604.3(9) & 4901.2(13) & 69.4(5)\end{array}$

Table S3. Anisotropic Displacement Parameters $\left(\AA^{2} \times 10^{3}\right)$ for Compound 2. The Anisotropic displacement factor exponent takes the form: $-2 \pi^{2}\left[\mathrm{~h}^{2} \mathrm{a} * 2 \mathrm{U}_{11}+2 \mathrm{hka} \mathrm{b}^{*} \mathrm{U}_{12}+\ldots\right]$.

\begin{tabular}{lrrrrrr} 
Atom & $\mathbf{U}_{\mathbf{1 1}}$ & $\mathbf{U}_{\mathbf{2 2}}$ & $\mathbf{U}_{\mathbf{3 3}}$ & $\mathbf{U}_{\mathbf{2 3}}$ & \multicolumn{1}{c}{$\mathbf{U}_{\mathbf{1 3}}$} & \multicolumn{1}{c}{$\mathbf{U}_{\mathbf{1 2}}$} \\
$\mathrm{C} 1$ & $37.3(7)$ & $29.8(7)$ & $30.3(8)$ & $1.7(6)$ & $0.7(6)$ & $-1.1(6)$ \\
$\mathrm{C} 2$ & $28.1(6)$ & $28.3(7)$ & $29.4(7)$ & $-0.2(5)$ & $0.5(5)$ & $0.7(5)$ \\
$\mathrm{C} 3$ & $40.9(8)$ & $36.3(8)$ & $31.7(8)$ & $1.6(6)$ & $-2.8(6)$ & $-6.4(6)$ \\
$\mathrm{C} 4$ & $50.4(9)$ & $39.0(8)$ & $35.0(8)$ & $-0.9(6)$ & $-2.2(7)$ & $12.0(7)$ \\
N1 & $36.3(7)$ & $43.9(8)$ & $58.7(9)$ & $10.8(7)$ & $-4.6(7)$ & $2.7(6)$ \\
N2 & $59.5(9)$ & $32.7(7)$ & $49.9(9)$ & $-5.3(6)$ & $-20.4(7)$ & $2.0(7)$ \\
O1 & $41.5(6)$ & $43.4(6)$ & $38.5(6)$ & $2.0(5)$ & $-3.9(5)$ & $11.1(5)$ \\
O2 & $55.5(8)$ & $77.3(10)$ & $73.4(10)$ & $3.1(7)$ & $5.1(7)$ & $30.4(7)$ \\
O3 & $52.3(7)$ & $80.4(10)$ & $56.3(8)$ & $15.5(7)$ & $-17.7(6)$ & $2.1(7)$ \\
O4 & $56.3(7)$ & $34.4(6)$ & $32.8(6)$ & $-0.2(4)$ & $-9.2(5)$ & $-9.8(5)$ \\
O5 & $113.0(13)$ & $64.0(9)$ & $40.4(8)$ & $-14.1(6)$ & $-20.9(7)$ & $3.5(8)$ \\
O6 & $85.2(10)$ & $48.3(8)$ & $74.8(10)$ & $3.1(7)$ & $-21.4(8)$ & $-29.5(8)$
\end{tabular}


Table S4. Bond Lengths for Compound 2.

\begin{tabular}{|c|c|c|c|c|c|}
\hline \multicolumn{2}{|c|}{ Atom Atom } & Length/Å & \multicolumn{2}{|c|}{ Atom Atom } & Length/Å \\
\hline $\mathrm{C} 1$ & $\mathrm{C} 1^{1}$ & $1.562(3)$ & N1 & $\mathrm{O} 1$ & $1.3847(17)$ \\
\hline $\mathrm{C} 1$ & $\mathrm{C} 2$ & $1.5524(19)$ & N1 & $\mathrm{O} 2$ & $1.2001(19)$ \\
\hline $\mathrm{C} 1$ & $\mathrm{C} 4$ & $1.507(2)$ & N1 & $\mathrm{O} 3$ & $1.2055(18)$ \\
\hline $\mathrm{C} 2$ & $\mathrm{C} 2^{1}$ & $1.548(3)$ & $\mathrm{N} 2$ & $\mathrm{O} 4$ & $1.3841(16)$ \\
\hline $\mathrm{C} 2$ & $\mathrm{C} 3$ & $1.5041(19)$ & $\mathrm{N} 2$ & $\mathrm{O} 5$ & $1.1936(19)$ \\
\hline $\mathrm{C} 3$ & $\mathrm{O} 4$ & $1.4503(17)$ & $\mathrm{N} 2$ & O6 & $1.1990(19)$ \\
\hline $\mathrm{C} 4$ & O1 & $1.4528(18)$ & & & \\
\hline
\end{tabular}

Table S5. Bond Angles for Compound 2.

\begin{tabular}{|c|c|c|c|c|c|c|c|}
\hline \multicolumn{3}{|c|}{ Atom Atom Atom } & \multirow{2}{*}{$\begin{array}{l}\text { Angle }^{\circ} \\
89.09(7)\end{array}$} & \multicolumn{3}{|c|}{ Atom Atom Atom } & \multirow{2}{*}{$\begin{array}{c}\text { Angle }^{\circ} \\
118.12(14)\end{array}$} \\
\hline $\mathrm{C} 2$ & $\mathrm{C} 1$ & $\mathrm{C} 1^{1}$ & & $\mathrm{O} 2$ & N1 & $\mathrm{O} 1$ & \\
\hline $\mathrm{C} 4$ & $\mathrm{C} 1$ & $\mathrm{C}^{1}{ }^{1}$ & $110.75(13)$ & $\mathrm{O} 2$ & N1 & $\mathrm{O} 3$ & $128.92(15)$ \\
\hline $\mathrm{C} 4$ & $\mathrm{C} 1$ & $\mathrm{C} 2$ & $119.44(12)$ & $\mathrm{O} 3$ & N1 & O1 & $112.96(14)$ \\
\hline $\mathrm{C} 2^{1}$ & $\mathrm{C} 2$ & $\mathrm{C} 1$ & 89.61(7) & $\mathrm{O} 5$ & $\mathrm{~N} 2$ & $\mathrm{O} 4$ & $113.32(15)$ \\
\hline $\mathrm{C} 3$ & $\mathrm{C} 2$ & $\mathrm{C} 1$ & $122.72(11)$ & $\mathrm{O} 5$ & $\mathrm{~N} 2$ & O6 & $128.60(15)$ \\
\hline C3 & $\mathrm{C} 2$ & $\mathrm{C} 2^{1}$ & $114.85(11)$ & O6 & $\mathrm{N} 2$ & $\mathrm{O} 4$ & $118.08(14)$ \\
\hline $\mathrm{O} 4$ & $\mathrm{C} 3$ & $\mathrm{C} 2$ & $106.16(11)$ & N1 & $\mathrm{O} 1$ & $\mathrm{C} 4$ & $114.01(11)$ \\
\hline $\mathrm{O} 1$ & $\mathrm{C} 4$ & $\mathrm{C} 1$ & $106.04(11)$ & $\mathrm{N} 2$ & $\mathrm{O} 4$ & $\mathrm{C} 3$ & $114.29(11)$ \\
\hline
\end{tabular}

Table S6. Torsion Angles for Compound 2.

\begin{tabular}{|c|c|c|c|}
\hline $\begin{array}{llll}\mathbf{A} & \mathbf{B} & \mathbf{C} & \mathbf{D}\end{array}$ & Angle ${ }^{\circ}$ & $\begin{array}{llll}\mathbf{A} & \mathbf{B} & \mathbf{C} & \mathbf{D}\end{array}$ & Angle $/^{\circ}$ \\
\hline $\mathrm{C} 1^{1} \mathrm{C} 1 \mathrm{C} 2 \mathrm{C} 2^{1}$ & $-12.18(13)$ & $\mathrm{C} 2 \mathrm{C} 3 \mathrm{O} 4 \mathrm{~N} 2$ & $-164.11(12)$ \\
\hline $\mathrm{C} 1{ }^{1} \mathrm{C} 1 \mathrm{C} 2 \mathrm{C} 3$ & $-131.86(14)$ & $\mathrm{C} 4 \mathrm{C} 1 \mathrm{C} 2 \mathrm{C} 2^{1}$ & $101.27(14)$ \\
\hline $\mathrm{C} 1{ }^{1} \mathrm{C} 1 \mathrm{C} 4 \mathrm{O} 1$ & $-178.87(9)$ & $\mathrm{C} 4 \mathrm{C} 1 \mathrm{C} 2 \mathrm{C} 3$ & $-18.41(19)$ \\
\hline $\mathrm{C} 1 \mathrm{C} 2 \mathrm{C} 3 \mathrm{O} 4$ & $-78.32(15)$ & $\mathrm{O} 2 \mathrm{~N} 1 \mathrm{O} 1 \mathrm{C} 4$ & $2.8(2)$ \\
\hline $\mathrm{C} 1 \mathrm{C} 4 \mathrm{O} 1 \mathrm{~N} 1$ & $169.33(12)$ & O3 N1 O1 C4 & $-177.57(13)$ \\
\hline $\mathrm{C} 2 \mathrm{C} 1 \mathrm{C} 4 \mathrm{O} 1$ & $79.93(15)$ & $\mathrm{O} 5 \mathrm{~N} 2 \mathrm{O} 4 \mathrm{C} 3$ & $174.64(14)$ \\
\hline $\mathrm{C} 2{ }^{1} \mathrm{C} 2 \mathrm{C} 3 \mathrm{O} 4$ & 174.92(11) & $\mathrm{O} 6 \mathrm{~N} 2 \mathrm{O} 4 \mathrm{C} 3$ & $-5.3(2)$ \\
\hline
\end{tabular}




\section{Compound 3}

CCDC 1935554

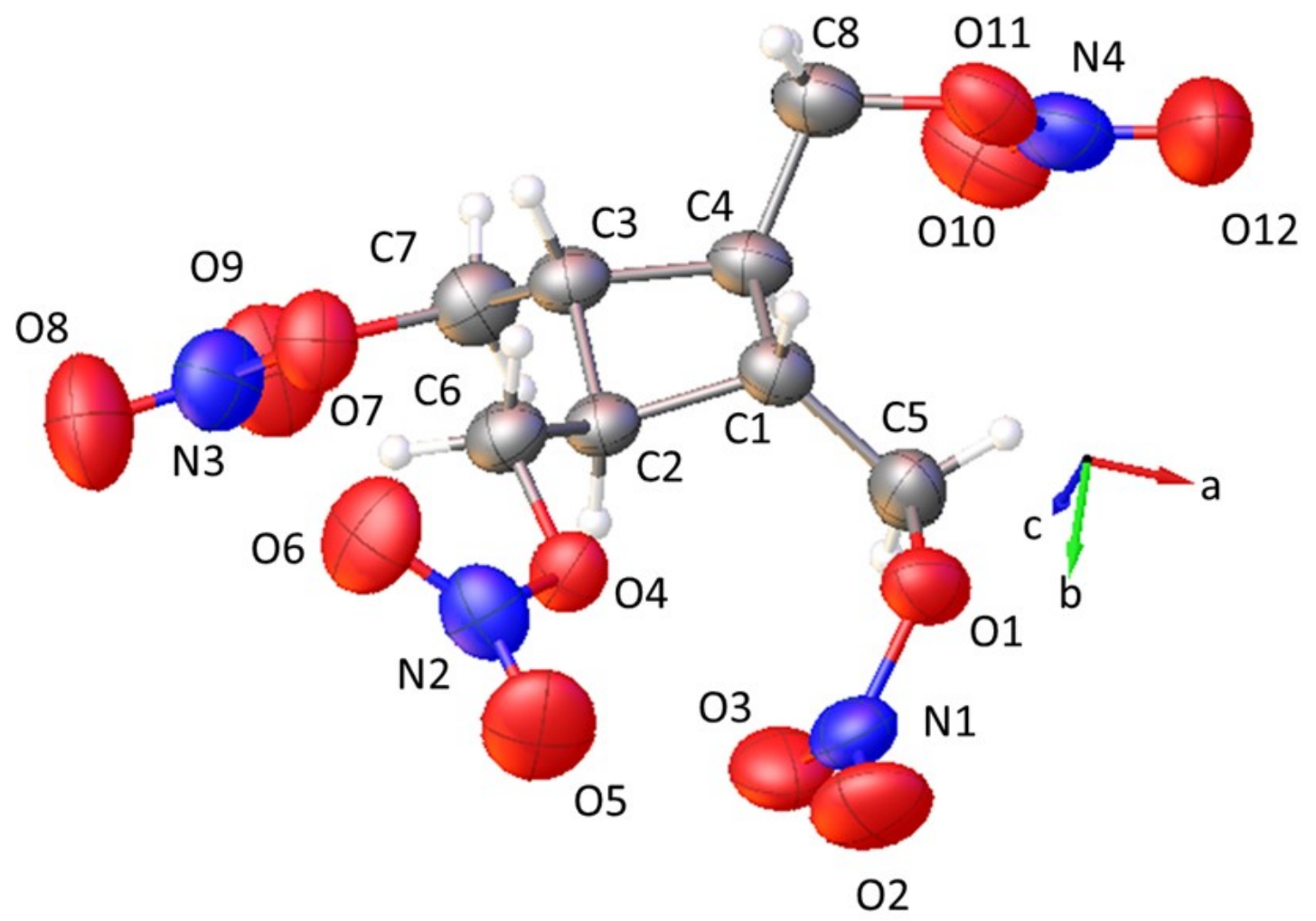

Figure S2. Molecular conformation and atom-numbering scheme for Compound 3. Nonhydrogen atoms are shown as $50 \%$ probability displacement ellipsoids. 
Table S7. Crystal data and structure refinement for Compound 3.

Empirical formula

Formula weight

Temperature/K

Crystal system

Space group

$\mathrm{a} / \AA \AA$

$\mathrm{b} / \AA$

$\mathrm{c} / \AA$

$\alpha /{ }^{\circ}$

$\beta /{ }^{\circ}$

$\gamma^{\circ}$

Volume $/ \AA^{3}$

Z

$\rho_{\text {calc }} / \mathrm{cm}^{3}$

$\mu / \mathrm{mm}^{-1}$

$\mathrm{F}(000)$

Crystal size $/ \mathrm{mm}^{3}$

Radiation

$2 \Theta$ range

Index ranges

Reflections collected

Independent reflections

Data/restraints/parameters

Goodness-of-fit on $\mathrm{F}^{2}$

Final $\mathrm{R}$ indexes $[\mathrm{I}>=2 \sigma(\mathrm{I})]$

Final $\mathrm{R}$ indexes [all data]

Largest diff. peak/hole / e $\AA^{-3}$

Flack parameter
$\mathrm{C}_{8} \mathrm{H}_{12} \mathrm{~N}_{4} \mathrm{O}_{12}$

356.22

298.00(10)

monoclinic

$\mathrm{P} 21$

7.6027(4)

9.8312(4)

$9.8783(4)$

90

93.581(5)

90

$736.90(6)$

2

1.605

0.154

368.0

$0.32 \times 0.23 \times 0.21$

$\operatorname{MoK} \alpha(\lambda=0.71073)$

4.132 to 50.7

$-9 \leq \mathrm{h} \leq 8,-11 \leq \mathrm{k} \leq 11,-11 \leq 1 \leq 11$

5945

$2668\left[\mathrm{R}_{\text {int }}=0.0200, \mathrm{R}_{\text {sigma }}=0.0290\right]$

$2668 / 1 / 217$

1.053

$\mathrm{R}_{1}=0.0399, \mathrm{wR}_{2}=0.0725$

$\mathrm{R}_{1}=0.0472, \mathrm{wR}_{2}=0.0757$

$\mathrm{A}^{-3} 0.12 /-0.12$

$-0.1(5)$ 
Table S8. Fractional Atomic Coordinates $\left(\times 10^{4}\right)$ and Equivalent Isotropic Displacement Parameters $\left(\AA^{2} \times 10^{3}\right)$ for 3 . $U_{\text {eq }}$ is defined as $1 / 3$ of of the trace of the orthogonalised $U_{\text {IJ }}$ tensor.

\begin{tabular}{lrrrr} 
Atom & $\boldsymbol{x}$ & $\boldsymbol{y}$ & $\boldsymbol{z}$ & \multicolumn{1}{|c}{$(\mathbf{e q )}$} \\
O1 & $6350(4)$ & $6329(3)$ & $1561(3)$ & $58.0(7)$ \\
O2 & $6114(5)$ & $8510(3)$ & $1580(4)$ & $86.7(10)$ \\
O3 & $5505(4)$ & $7410(3)$ & $3386(3)$ & $73.7(8)$ \\
O4 & $2297(3)$ & $7007(2)$ & $1382(2)$ & $45.9(6)$ \\
O5 & $1991(4)$ & $8992(3)$ & $462(3)$ & $87.2(10)$ \\
O6 & $-227(4)$ & $7612(3)$ & $309(3)$ & $78.5(10)$ \\
O7 & $-170(3)$ & $3841(3)$ & $4275(2)$ & $58.2(7)$ \\
O8 & $-2234(4)$ & $4383(4)$ & $5591(3)$ & $98.6(12)$ \\
O9 & $-99(5)$ & $3111(4)$ & $6408(3)$ & $92.1(11)$ \\
O10 & $6261(4)$ & $1581(2)$ & $1662(3)$ & $61.8(7)$ \\
O11 & $6848(5)$ & $947(4)$ & $3789(4)$ & $92.9(12)$ \\
O12 & $8898(5)$ & $1026(4)$ & $2384(5)$ & $112.6(14)$ \\
N1 & $5965(4)$ & $7513(3)$ & $2248(4)$ & $56.9(9)$ \\
N2 & $1246(5)$ & $7936(4)$ & $654(3)$ & $57.7(8)$ \\
N3 & $-882(5)$ & $3756(4)$ & $5541(3)$ & $67.3(10)$ \\
N4 & $7403(6)$ & $1152(4)$ & $2712(5)$ & $72.3(10)$ \\
C1 & $4424(4)$ & $4388(3)$ & $1963(3)$ & $40.1(8)$ \\
C2 & $2720(4)$ & $4945(3)$ & $2543(3)$ & $37.2(7)$ \\
C3 & $2196(4)$ & $3467(3)$ & $2881(3)$ & $40.9(8)$ \\
C4 & $4136(5)$ & $3034(4)$ & $2715(3)$ & $43.7(8)$ \\
C5 & $6170(5)$ & $5065(4)$ & $2299(4)$ & $53.8(9)$ \\
C6 & $1438(5)$ & $5721(4)$ & $1631(3)$ & $45.4(9)$ \\
C7 & $1535(5)$ & $3177(4)$ & $4251(3)$ & $49.7(9)$ \\
C8 & $4436(5)$ & $1712(4)$ & $1996(4)$ & $52.3(9)$
\end{tabular}


Table S9. Anisotropic Displacement Parameters $\left(\AA^{2} \times 10^{3}\right)$ for Compound 3. The Anisotropic displacement factor exponent takes the form: $-2 \pi^{2}\left[\mathrm{~h}^{2} \mathrm{a} * 2 \mathrm{U}_{11}+2 \mathrm{hka} * \mathrm{~b} * \mathrm{U}_{12}+\ldots\right]$.

\begin{tabular}{lrrrrrr} 
Atom & \multicolumn{1}{c}{$\mathbf{U}_{\mathbf{1 1}}$} & \multicolumn{1}{c}{$\mathbf{U}_{\mathbf{2 2}}$} & \multicolumn{1}{c}{$\mathbf{U}_{\mathbf{3 3}}$} & \multicolumn{1}{c}{$\mathbf{U}_{\mathbf{2 3}}$} & \multicolumn{1}{c}{$\mathbf{U}_{\mathbf{1 3}}$} & \multicolumn{1}{c}{$\mathbf{U}_{\mathbf{1 2}}$} \\
O1 & $67.4(19)$ & $42.9(15)$ & $65.4(15)$ & $-1.9(13)$ & $16.9(13)$ & $-6.3(13)$ \\
O2 & $107(3)$ & $42.1(17)$ & $110(2)$ & $13.0(17)$ & $-2.4(19)$ & $-14.0(17)$ \\
O3 & $81(2)$ & $75(2)$ & $63.3(18)$ & $-21.6(16)$ & $-4.5(15)$ & $-4.8(17)$ \\
O4 & $45.2(14)$ & $39.1(13)$ & $52.8(13)$ & $12.7(10)$ & $-2.3(11)$ & $2.4(11)$ \\
O5 & $100(2)$ & $53.8(18)$ & $109(2)$ & $37.9(19)$ & $10.0(18)$ & $1.4(19)$ \\
O6 & $63.5(19)$ & $89(2)$ & $79.8(19)$ & $28.0(17)$ & $-22.0(16)$ & $8.1(17)$ \\
O7 & $55.2(16)$ & $74.4(19)$ & $45.3(13)$ & $15.7(13)$ & $6.1(11)$ & $4.6(15)$ \\
O8 & $73(2)$ & $137(3)$ & $87(2)$ & $11(2)$ & $24.9(18)$ & $20(2)$ \\
O9 & $108(3)$ & $110(3)$ & $60.9(17)$ & $39(2)$ & $24.4(18)$ & $12(2)$ \\
O10 & $82(2)$ & $40.3(16)$ & $64.2(16)$ & $2.5(12)$ & $16.6(15)$ & $9.1(14)$ \\
O11 & $129(3)$ & $81(2)$ & $67(2)$ & $7.8(17)$ & $-6(2)$ & $27(2)$ \\
O12 & $70(3)$ & $92(3)$ & $177(4)$ & $-23(3)$ & $12(3)$ & $3(2)$ \\
N1 & $52(2)$ & $49(2)$ & $68(2)$ & $-6.1(19)$ & $-8.0(17)$ & $-8.4(17)$ \\
N2 & $66(2)$ & $55(2)$ & $52.3(18)$ & $15.3(16)$ & $3.1(16)$ & $13.8(19)$ \\
N3 & $70(3)$ & $77(3)$ & $56(2)$ & $9.2(19)$ & $17.3(19)$ & $-5(2)$ \\
N4 & $81(3)$ & $44(2)$ & $91(3)$ & $-9(2)$ & $-2(3)$ & $5(2)$ \\
C1 & $47(2)$ & $36.0(18)$ & $36.6(16)$ & $0.3(14)$ & $2.1(14)$ & $1.6(16)$ \\
C2 & $42(2)$ & $35.3(17)$ & $33.5(16)$ & $-0.5(13)$ & $-4.2(13)$ & $-3.6(16)$ \\
C3 & $49(2)$ & $37.8(18)$ & $35.6(16)$ & $0.1(14)$ & $-4.2(14)$ & $-4.5(16)$ \\
C4 & $55(2)$ & $32.9(17)$ & $42.0(17)$ & $-1.3(15)$ & $-2.0(15)$ & $1.3(17)$ \\
C5 & $48(2)$ & $44(2)$ & $70(2)$ & $2.9(19)$ & $4.6(17)$ & $5.0(19)$ \\
C6 & $46(2)$ & $42.1(19)$ & $46.9(19)$ & $2.0(15)$ & $-6.9(16)$ & $-3.4(17)$ \\
C7 & $57(2)$ & $48(2)$ & $44.3(18)$ & $10.7(16)$ & $1.5(16)$ & $-1.8(19)$ \\
C8 & $62(3)$ & $40(2)$ & $54(2)$ & $-1.0(16)$ & $-2.2(18)$ & $2.6(19)$
\end{tabular}


Table S10. Bond Lengths for Compound 3.

\begin{tabular}{|c|c|c|c|c|c|}
\hline \multicolumn{2}{|c|}{ Atom Atom } & Length/Å & \multicolumn{2}{|c|}{ Atom Atom } & Length/Å \\
\hline $\mathrm{O} 1$ & N1 & $1.389(4)$ & $\mathrm{O} 10$ & N4 & $1.376(5)$ \\
\hline $\mathrm{O} 1$ & $\mathrm{C} 5$ & $1.452(4)$ & O10 & $\mathrm{C} 8$ & $1.452(4)$ \\
\hline $\mathrm{O} 2$ & N1 & $1.191(4)$ & O11 & N4 & $1.185(5)$ \\
\hline $\mathrm{O} 3$ & N1 & $1.202(4)$ & O12 & N4 & $1.208(5)$ \\
\hline $\mathrm{O} 4$ & N2 & $1.386(3)$ & $\mathrm{C} 1$ & $\mathrm{C} 2$ & $1.549(5)$ \\
\hline $\mathrm{O} 4$ & C6 & $1.450(4)$ & $\mathrm{C} 1$ & $\mathrm{C} 4$ & $1.547(5)$ \\
\hline $\mathrm{O} 5$ & $\mathrm{~N} 2$ & $1.203(4)$ & $\mathrm{C} 1$ & $\mathrm{C} 5$ & $1.503(5)$ \\
\hline O6 & N2 & $1.193(4)$ & $\mathrm{C} 2$ & $\mathrm{C} 3$ & $1.548(4)$ \\
\hline $\mathrm{O} 7$ & N3 & $1.395(4)$ & $\mathrm{C} 2$ & C6 & $1.495(4)$ \\
\hline $\mathrm{O} 7$ & $\mathrm{C} 7$ & $1.453(4)$ & $\mathrm{C} 3$ & $\mathrm{C} 4$ & $1.554(5)$ \\
\hline O8 & N3 & $1.203(4)$ & $\mathrm{C} 3$ & $\mathrm{C} 7$ & $1.501(4)$ \\
\hline O9 & N3 & $1.194(4)$ & $\mathrm{C} 4$ & $\mathrm{C} 8$ & $1.505(5)$ \\
\hline
\end{tabular}

Table S11. Bond Angles for Compound 3.

\begin{tabular}{|c|c|c|c|c|c|c|c|}
\hline \multicolumn{3}{|c|}{ Atom Atom Atom } & Angle $/^{\circ}$ & \multicolumn{3}{|c|}{ Atom Atom Atom } & \multirow{2}{*}{$\begin{array}{c}\text { Angle/ } \\
88.8(2)\end{array}$} \\
\hline N1 & $\mathrm{O} 1$ & $\mathrm{C} 5$ & $116.3(3)$ & $\mathrm{C} 4$ & $\mathrm{C} 1$ & $\mathrm{C} 2$ & \\
\hline N2 & $\mathrm{O} 4$ & C6 & $114.3(3)$ & C5 & $\mathrm{C} 1$ & $\mathrm{C} 2$ & $120.6(3)$ \\
\hline N3 & $\mathrm{O} 7$ & $\mathrm{C} 7$ & $112.6(3)$ & $\mathrm{C} 5$ & $\mathrm{C} 1$ & $\mathrm{C} 4$ & $115.1(3)$ \\
\hline N4 & $\mathrm{O} 10$ & $\mathrm{C} 8$ & $115.0(3)$ & C3 & $\mathrm{C} 2$ & $\mathrm{C} 1$ & $88.9(2)$ \\
\hline $\mathrm{O} 2$ & N1 & O1 & $112.9(3)$ & C6 & $\mathrm{C} 2$ & $\mathrm{C} 1$ & 119.1(3) \\
\hline $\mathrm{O} 2$ & N1 & $\mathrm{O} 3$ & $129.1(4)$ & C6 & $\mathrm{C} 2$ & $\mathrm{C} 3$ & $116.2(3)$ \\
\hline $\mathrm{O} 3$ & N1 & $\mathrm{O} 1$ & $118.0(3)$ & $\mathrm{C} 2$ & C3 & $\mathrm{C} 4$ & $88.6(2)$ \\
\hline $\mathrm{O} 5$ & $\mathrm{~N} 2$ & $\mathrm{O} 4$ & $112.9(3)$ & $\mathrm{C} 7$ & $\mathrm{C} 3$ & $\mathrm{C} 2$ & $118.5(3)$ \\
\hline O6 & $\mathrm{N} 2$ & $\mathrm{O} 4$ & $118.2(3)$ & $\mathrm{C} 7$ & C3 & $\mathrm{C} 4$ & $114.6(3)$ \\
\hline O6 & $\mathrm{N} 2$ & O5 & $128.9(3)$ & $\mathrm{C} 1$ & $\mathrm{C} 4$ & C3 & $88.8(2)$ \\
\hline $\mathrm{O} 8$ & N3 & $\mathrm{O} 7$ & $112.7(3)$ & $\mathrm{C} 8$ & $\mathrm{C} 4$ & $\mathrm{C} 1$ & $119.1(3)$ \\
\hline O9 & N3 & $\mathrm{O} 7$ & $118.1(4)$ & $\mathrm{C} 8$ & $\mathrm{C} 4$ & C3 & $117.3(3)$ \\
\hline O9 & N3 & $\mathrm{O} 8$ & $129.2(4)$ & $\mathrm{O} 1$ & C5 & $\mathrm{C} 1$ & $112.2(3)$ \\
\hline O11 & N4 & $\mathrm{O} 10$ & $119.0(4)$ & $\mathrm{O} 4$ & C6 & $\mathrm{C} 2$ & $105.3(2)$ \\
\hline O11 & N4 & $\mathrm{O} 12$ & $128.1(5)$ & $\mathrm{O} 7$ & $\mathrm{C} 7$ & C3 & $106.2(3)$ \\
\hline $\mathrm{O} 12$ & N4 & $\mathrm{O} 10$ & $112.9(5)$ & O10 & $\mathrm{C} 8$ & $\mathrm{C} 4$ & $111.1(3)$ \\
\hline
\end{tabular}


Table S12. Torsion Angles for Compound 3.

\begin{tabular}{|c|c|c|c|}
\hline $\begin{array}{llll}\mathbf{A} & \mathbf{B} & \mathbf{C} & \mathbf{D}\end{array}$ & Angle $/^{\circ}$ & A $\mathbf{B}$ & Angle $/^{\circ}$ \\
\hline N1 O1 C5C1 & $97.1(3)$ & $\mathrm{C} 4 \mathrm{C} 1 \mathrm{C} 5 \mathrm{O} 1$ & $-179.9(3)$ \\
\hline $\mathrm{N} 2 \mathrm{O} 4 \mathrm{C} 6 \mathrm{C} 2$ & $-174.1(3)$ & $\mathrm{C} 7 \mathrm{O} 7$ & $171.2(3)$ \\
\hline N3O7 C7C3 & $-174.8(3)$ & $\mathrm{C} 5 \mathrm{O} 1 \mathrm{~N} 1 \mathrm{O} 2$ & $-179.0(3)$ \\
\hline N4 O10C8C4 & $80.7(4)$ & $\mathrm{C} 5 \mathrm{O} 1 \mathrm{~N} 1 \mathrm{O} 3$ & $-0.5(4)$ \\
\hline $\mathrm{C} 1 \mathrm{C} 2 \mathrm{C} 3 \mathrm{C} 4$ & $16.6(2)$ & $\mathrm{C} 5 \mathrm{C} 1 \mathrm{C} 2 \mathrm{C} 3$ & $-135.4(3)$ \\
\hline $\mathrm{C} 1 \mathrm{C} 2 \quad \mathrm{C} 3 \mathrm{C} 7$ & $134.1(3)$ & $\mathrm{C} 5 \mathrm{C} 1 \mathrm{C} 2 \mathrm{C} 6$ & $104.9(3)$ \\
\hline $\mathrm{C} 1 \mathrm{C} 2 \quad \mathrm{C} 6 \mathrm{O} 4$ & $-70.7(3)$ & $\mathrm{C} 5 \mathrm{C} 1 \mathrm{C} 4 \mathrm{C} 3$ & $140.2(3)$ \\
\hline $\mathrm{C} 1 \mathrm{C} 4 \mathrm{C} 8 \mathrm{O} 10$ & $62.8(4)$ & $\mathrm{C} 5 \mathrm{C} 1 \mathrm{C} 4 \mathrm{C} 8$ & $-98.9(4)$ \\
\hline $\mathrm{C} 2 \mathrm{C} 1 \quad \mathrm{C} 4 \mathrm{C} 3$ & $16.6(2)$ & $\mathrm{C} 6 \mathrm{O} 4 \mathrm{~N} 2 \mathrm{O} 5$ & $-180.0(3)$ \\
\hline $\mathrm{C} 2 \mathrm{C} 1 \mathrm{C} 4 \mathrm{C} 8$ & $137.5(3)$ & $\mathrm{C} 6 \mathrm{O} 4 \mathrm{~N} 2 \mathrm{O} 6$ & $0.2(4)$ \\
\hline $\mathrm{C} 2 \mathrm{C} 1 \mathrm{C} 5 \mathrm{O} 1$ & $-75.4(4)$ & $\mathrm{C} 6 \mathrm{C} 2 \mathrm{C} 3 \mathrm{C} 4$ & $138.8(3)$ \\
\hline $\mathrm{C} 2 \mathrm{C} 3 \mathrm{C} 4 \mathrm{C} 1$ & $-16.6(2)$ & $\mathrm{C} 6 \mathrm{C} 2 \quad \mathrm{C} 3 \mathrm{C} 7$ & $-103.7(4)$ \\
\hline $\mathrm{C} 2 \mathrm{C} 3 \mathrm{C} 4 \mathrm{C} 8$ & $-139.1(3)$ & $\mathrm{C} 7 \mathrm{O} 7 \mathrm{~N} 3 \mathrm{O} 8$ & $175.2(4)$ \\
\hline $\mathrm{C} 2 \mathrm{C} 3 \mathrm{C} 7 \mathrm{O} 7$ & $68.5(4)$ & C7O7 N3O9 & $-4.1(5)$ \\
\hline $\mathrm{C} 3 \mathrm{C} 2 \mathrm{C} 6 \mathrm{O} 4$ & $-175.1(3)$ & $\mathrm{C} 7 \mathrm{C} 3 \mathrm{C} 4 \mathrm{C} 1$ & $-137.6(3)$ \\
\hline $\mathrm{C} 3 \mathrm{C} 4 \mathrm{C} 8 \mathrm{O} 10$ & $167.8(3)$ & $\mathrm{C} 7 \mathrm{C} 3 \mathrm{C} 4 \mathrm{C} 8$ & $100.0(4)$ \\
\hline $\mathrm{C} 4 \mathrm{C} 1 \quad \mathrm{C} 2 \mathrm{C} 3$ & $-16.7(2)$ & C8O10 N4O11 & $-1.2(5)$ \\
\hline $\mathrm{C} 4 \mathrm{C} 1 \mathrm{C} 2 \mathrm{C} 6$ & $-136.4(3)$ & C8O10 N4O12 & $178.4(3)$ \\
\hline
\end{tabular}




\section{Compound 5}

CCDC 1935555

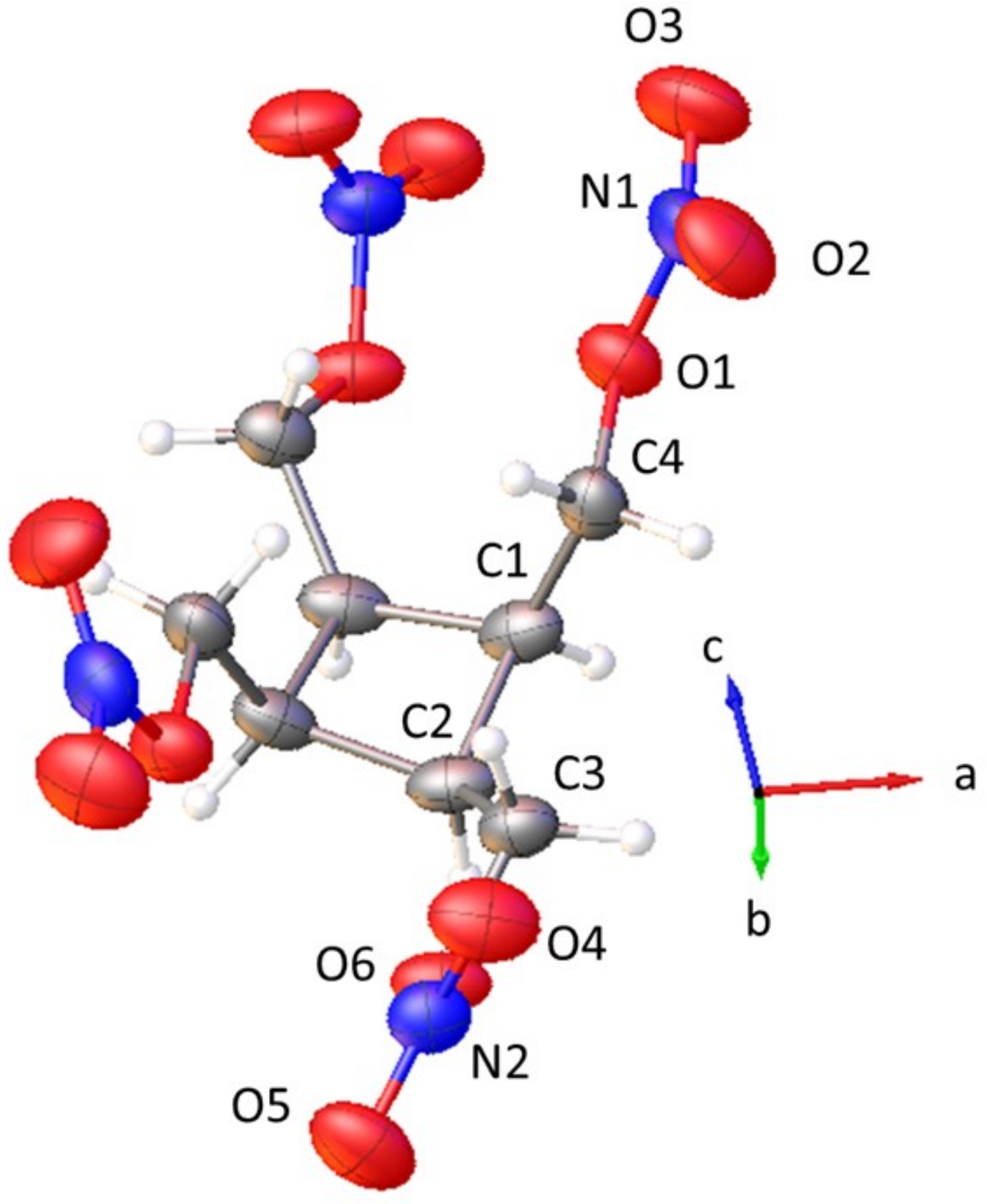

Figure S3. Molecular conformation and atom-numbering scheme for Compound 5. Nonlabeled atoms are generated by inversion $(1-\mathrm{x}, \mathrm{y}, 3 / 2-\mathrm{z})$. Non-hydrogen atoms are shown as $50 \%$ probability displacement ellipsoids. 
Table S13. Crystal data and structure refinement for Compound 5.

Empirical formula

$\mathrm{C}_{8} \mathrm{H}_{12} \mathrm{~N}_{4} \mathrm{O}_{12}$

Formula weight

356.22

Temperature/K

298.00(10)

Crystal system

monoclinic

Space group

$\mathrm{C} 2 / \mathrm{c}$

$\mathrm{a} / \AA$

$12.8079(4)$

$\mathrm{b} / \AA$

9.3371(3)

$\mathrm{c} / \AA$

$12.0047(4)$

$\alpha{ }^{\circ}$

90

$\beta /{ }^{\circ}$

$\gamma /{ }^{\circ}$

95.751(3)

90

Volume $/ \AA^{3}$

$1428.40(8)$

Z

4

$\rho_{\text {calc }} / \mathrm{cm}^{3}$

1.656

$\mu / \mathrm{mm}^{-1}$

0.159

$\mathrm{F}(000)$

736.0

Crystal size $/ \mathrm{mm}^{3}$

$0.32 \times 0.23 \times 0.21$

Radiation

$\operatorname{MoK} \alpha(\lambda=0.71073)$

$2 \Theta$ range for data collection $/{ }^{\circ} 5.408$ to 52.742

Index ranges

$-16 \leq \mathrm{h} \leq 15,-11 \leq \mathrm{k} \leq 11,-15 \leq 1 \leq 15$

Reflections collected

5975

Independent reflections

Data/restraints/parameters

$1460\left[\mathrm{R}_{\text {int }}=0.0173, \mathrm{R}_{\text {sigma }}=0.0140\right]$

Goodness-of-fit on $\mathrm{F}^{2}$

$1460 / 0 / 110$

Final R indexes $[\mathrm{I}>=2 \sigma(\mathrm{I})]$

1.096

Final $\mathrm{R}$ indexes [all data] $\quad \mathrm{R}_{1}=0.0364, \mathrm{wR}_{2}=0.0901$

Largest diff. peak/hole / e $\AA^{-3} 0.25 /-0.13$ 
Table S14. Fractional Atomic Coordinates $\left(\times 10^{4}\right)$ and Equivalent Isotropic Displacement Parameters $\left(\AA^{2} \times 10^{3}\right)$ for 5 . $\mathrm{U}_{\text {eq }}$ is defined as $1 / 3$ of of the trace of the orthogonalised $\mathrm{U}_{\mathrm{IJ}}$ tensor.

$\begin{array}{lcrrr}\text { Atom } & \boldsymbol{x} & \boldsymbol{y} & \boldsymbol{z} & \mathbf{U}(\mathbf{e q}) \\ \text { C1 } & 5844.8(11) & 8130.9(14) & 7801.9(10) & 37.3(3) \\ \text { C2 } & 5190.2(11) & 8386.8(13) & 6652(1) & 37.3(3) \\ \text { C3 } & 5438.9(11) & 7538.0(14) & 5642.8(10) & 36.7(3) \\ \text { C4 } & 6337.9(10) & 6662.5(15) & 7908.9(10) & 37.2(3) \\ \text { N1 } & 7209.9(9) & 5202.3(14) & 9340.8(11) & 46.7(3) \\ \text { N2 } & 4534.0(9) & 7270.0(13) & 3811.2(9) & 40.2(3) \\ \text { O1 } & 6727.8(7) & 6513.5(11) & 9083.5(8) & 43.2(3) \\ \text { O2 } & 7333.4(10) & 4401.5(14) & 8586.4(11) & 67.9(4) \\ \text { O3 } & 7439.9(11) & 5039.2(14) & 10325.7(9) & 69.8(4) \\ \text { O4 } & 4767.9(8) & 8162(1) & 4717.1(7) & 42.5(3) \\ \text { O5 } & 3968.8(10) & 7829.7(14) & 3077.5(9) & 62.4(4) \\ \text { O6 } & 4903.9(10) & 6086.3(12) & 3841.9(9) & 57.1(3)\end{array}$

Table S15. Anisotropic Displacement Parameters $\left(\AA^{2} \times 10^{3}\right)$ for Compound 5. The Anisotropic displacement factor exponent takes the form: $-2 \pi^{2}\left[h^{2} a * 2 U_{11}+2 h k a * b * U_{12}+\ldots\right]$.

\begin{tabular}{lcllrrr} 
Atom & $\mathbf{U}_{11}$ & $\mathbf{U}_{22}$ & $\mathbf{U}_{\mathbf{3 3}}$ & $\mathbf{U}_{\mathbf{2 3}}$ & \multicolumn{1}{c}{$\mathbf{U}_{\mathbf{1 3}}$} & \multicolumn{1}{c}{$\mathbf{U}_{\mathbf{1 2}}$} \\
$\mathrm{C} 1$ & $48.9(8)$ & $33.3(7)$ & $28.0(6)$ & $0.4(5)$ & $-3.6(5)$ & $-13.0(6)$ \\
$\mathrm{C} 2$ & $58.6(8)$ & $25.0(6)$ & $27.1(6)$ & $2.0(5)$ & $-1.6(5)$ & $-6.1(5)$ \\
$\mathrm{C} 3$ & $45.8(7)$ & $34.9(7)$ & $28.6(6)$ & $2.4(5)$ & $-0.1(5)$ & $-5.0(6)$ \\
C4 & $34.4(6)$ & $47.0(8)$ & $29.2(6)$ & $-2.9(5)$ & $-2.0(5)$ & $-1.8(6)$ \\
N1 & $36.6(6)$ & $51.4(7)$ & $49.9(7)$ & $3.9(6)$ & $-6.6(5)$ & $2.8(5)$ \\
N2 & $49.5(7)$ & $40.2(6)$ & $30.6(6)$ & $-4.0(5)$ & $2.6(5)$ & $-1.2(5)$ \\
O1 & $46.9(6)$ & $45.5(6)$ & $34.8(5)$ & $-1.7(4)$ & $-7.3(4)$ & $4.3(4)$ \\
O2 & $69.0(8)$ & $66.8(8)$ & $66.2(8)$ & $-11.0(6)$ & $-1.4(6)$ & $28.3(6)$ \\
O3 & $82.1(9)$ & $70.0(8)$ & $51.2(7)$ & $12.0(6)$ & $-22.9(6)$ & $3.3(7)$ \\
O4 & $69.4(7)$ & $29.8(5)$ & $26.6(5)$ & $-0.4(4)$ & $-2.7(4)$ & $1.0(4)$ \\
O5 & $70.4(8)$ & $72.1(8)$ & $40.4(6)$ & $-5.3(5)$ & $-16.3(5)$ & $15.6(6)$ \\
O6 & $86.5(8)$ & $39.8(6)$ & $43.9(6)$ & $-9.5(5)$ & $0.7(5)$ & $9.2(6)$
\end{tabular}


Table S16. Bond Lengths for Compound 5.

\begin{tabular}{|c|c|c|c|c|c|}
\hline \multicolumn{2}{|c|}{ Atom Atom } & \multirow{2}{*}{$\begin{array}{r}\text { Length/Å } \\
1.5552(19)\end{array}$} & \multicolumn{2}{|c|}{ Atom Atom } & \multirow{2}{*}{$\begin{array}{r}\text { Length/Å } \\
1.3918(15)\end{array}$} \\
\hline $\mathrm{C} 1$ & $\mathrm{C} 2^{1}$ & & N1 & $\mathrm{O} 1$ & \\
\hline $\mathrm{C} 1$ & $\mathrm{C} 2$ & $1.5600(17)$ & N1 & $\mathrm{O} 2$ & $1.1970(16)$ \\
\hline $\mathrm{C} 1$ & $\mathrm{C} 4$ & $1.5097(19)$ & N1 & $\mathrm{O} 3$ & $1.1993(16)$ \\
\hline $\mathrm{C} 2$ & $\mathrm{C} 1^{1}$ & $1.5552(19)$ & $\mathrm{N} 2$ & $\mathrm{O} 4$ & $1.3787(14)$ \\
\hline $\mathrm{C} 2$ & C3 & $1.5082(18)$ & $\mathrm{N} 2$ & O5 & $1.2021(15)$ \\
\hline C3 & $\mathrm{O} 4$ & $1.4566(15)$ & $\mathrm{N} 2$ & O6 & $1.2016(16)$ \\
\hline $\mathrm{C} 4$ & $\mathrm{O} 1$ & $1.4546(15)$ & & & \\
\hline
\end{tabular}

Table S17. Bond Angles for Compound 5.

\begin{tabular}{|c|c|c|c|c|c|c|c|}
\hline \multicolumn{3}{|c|}{ Atom Atom Atom } & Angle ${ }^{\circ}$ & \multicolumn{3}{|c|}{ Atom Atom Atom } & Angle $/^{\circ}$ \\
\hline $\mathrm{C} 2^{1}$ & $\mathrm{C} 1$ & $\mathrm{C} 2$ & $86.81(10)$ & $\mathrm{O} 2$ & N1 & $\mathrm{O} 1$ & $118.09(12)$ \\
\hline $\mathrm{C} 4$ & $\mathrm{C} 1$ & $\mathrm{C} 2^{1}$ & $118.08(11)$ & $\mathrm{O} 2$ & N1 & $\mathrm{O} 3$ & $128.95(14)$ \\
\hline $\mathrm{C} 4$ & $\mathrm{C} 1$ & $\mathrm{C} 2$ & $113.43(10)$ & $\mathrm{O} 3$ & N1 & O1 & $112.96(12)$ \\
\hline $\mathrm{C} 1^{1}$ & $\mathrm{C} 2$ & $\mathrm{C} 1$ & $90.50(10)$ & $\mathrm{O} 5$ & $\mathrm{~N} 2$ & $\mathrm{O} 4$ & $112.50(12)$ \\
\hline $\mathrm{C} 3$ & $\mathrm{C} 2$ & $\mathrm{C} 1$ & $119.49(12)$ & O6 & $\mathrm{N} 2$ & $\mathrm{O} 4$ & $118.53(11)$ \\
\hline $\mathrm{C} 3$ & $\mathrm{C} 2$ & $\mathrm{C} 1^{1}$ & $121.03(11)$ & O6 & $\mathrm{N} 2$ & O5 & $128.97(12)$ \\
\hline $\mathrm{O} 4$ & C3 & $\mathrm{C} 2$ & $104.28(11)$ & N1 & $\mathrm{O} 1$ & $\mathrm{C} 4$ & $113.62(10)$ \\
\hline $\mathrm{O} 1$ & $\mathrm{C} 4$ & $\mathrm{C} 1$ & $105.63(10)$ & $\mathrm{N} 2$ & $\mathrm{O} 4$ & C3 & $115.15(10)$ \\
\hline
\end{tabular}

${ }^{1} 1-X,+Y, 3 / 2-Z$

Table S18. Torsion Angles for Compound 5.

\begin{tabular}{|c|c|c|c|}
\hline $\begin{array}{llll}\mathbf{A} & \mathbf{B} & \mathbf{C} & \mathbf{D}\end{array}$ & Angle/ ${ }^{\circ}$ & $\begin{array}{llll}\mathbf{A} & \mathbf{B} & \mathbf{C} & \mathbf{D}\end{array}$ & Angle ${ }^{\circ}$ \\
\hline $\mathrm{C} 1 \mathrm{C} 2 \mathrm{C} 3 \mathrm{O} 4$ & $-173.82(10)$ & $\mathrm{C} 2 \mathrm{C} 3 \mathrm{O} 4 \mathrm{~N} 2$ & $-155.71(11)$ \\
\hline $\mathrm{C} 1{ }^{1} \mathrm{C} 2 \mathrm{C} 3 \mathrm{O} 4$ & $75.58(14)$ & $\mathrm{C} 4 \mathrm{C} 1 \mathrm{C} 2 \mathrm{C}^{1}{ }^{1}$ & $101.83(11)$ \\
\hline C1 C4O1N1 & $179.72(10)$ & $\mathrm{C} 4 \mathrm{C} 1 \mathrm{C} 2 \mathrm{C} 3$ & $-24.83(17)$ \\
\hline $\mathrm{C} 2{ }^{1} \mathrm{C} 1 \mathrm{C} 2 \mathrm{C} 1^{1}$ & $-17.48(13)$ & $\mathrm{O} 2 \mathrm{~N} 1 \mathrm{O} 1 \mathrm{C} 4$ & $6.02(17)$ \\
\hline $\mathrm{C} 2{ }^{1} \mathrm{C} 1 \mathrm{C} 2 \mathrm{C} 3$ & $-144.14(10)$ & O3 N1 O1 C4 & $-173.46(12)$ \\
\hline $\mathrm{C} 2 \mathrm{C} 1 \mathrm{C} 4 \mathrm{O} 1$ & $-168.92(10)$ & $\mathrm{O} 5 \mathrm{~N} 2 \mathrm{O} 4 \mathrm{C} 3$ & $179.15(12)$ \\
\hline $\mathrm{C} 2{ }^{1} \mathrm{C} 1 \mathrm{C} 4 \mathrm{O} 1$ & $-69.58(13)$ & O6 N2 O4C3 & $-1.21(17)$ \\
\hline
\end{tabular}

${ }^{1} 1-X,+Y, 3 / 2-Z$ 


\section{Compound 6}

CCDC 1935556

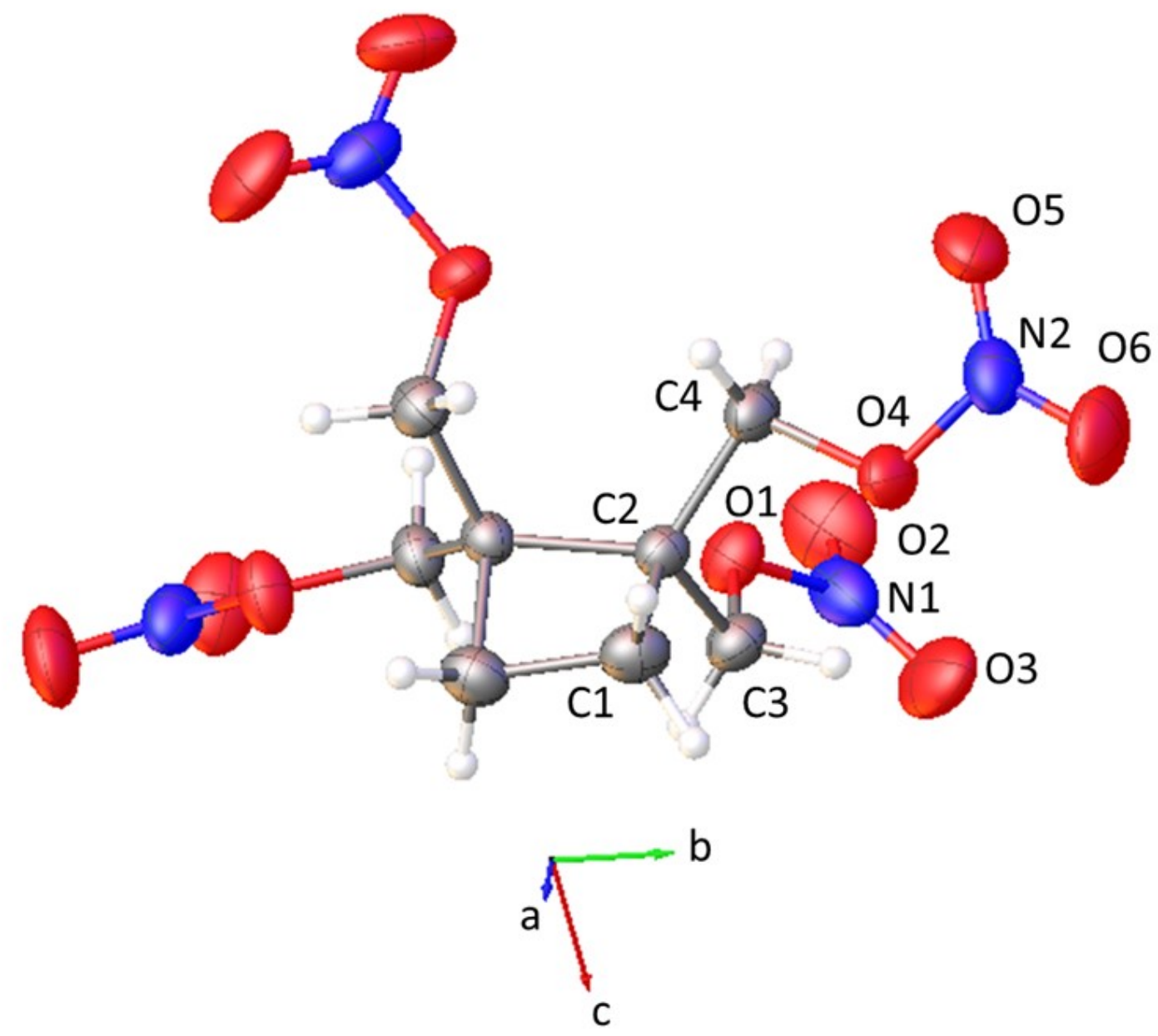

Figure S4. Molecular conformation and atom-numbering scheme for Compound 6. Non-labeled atoms are generated by inversion $(1-\mathrm{x}, 1-\mathrm{y}, \mathrm{z})$. Non-hydrogen atoms are shown as $50 \%$ probability displacement ellipsoids. 
Table S19. Crystal data and structure refinement for Compound $\mathbf{6 .}$

Empirical formula

Formula weight

Temperature/K

Crystal system

Space group

$\mathrm{a} / \AA$

$\mathrm{b} / \AA$

$\mathrm{c} / \AA$

$\alpha /^{\circ}$

$\beta /{ }^{\circ}$

$\gamma /{ }^{\circ}$

Volume $/ \AA^{3}$

Z

$\rho_{\text {calc }} \mathrm{g} / \mathrm{cm}^{3}$

$\mu / \mathrm{mm}^{-1}$

$\mathrm{F}(000)$

Crystal size $/ \mathrm{mm}^{3}$

Radiation
$\mathrm{C}_{8} \mathrm{H}_{12} \mathrm{~N}_{4} \mathrm{O}_{12}$

356.22

296(3)

orthorhombic

Fdd 2

26.9938(19)

17.3049(9)

$6.0736(5)$

90

90

90

2837.1(3)

8

1.668

0.160

1472.0

$0.3 \times 0.18 \times 0.03$

$\operatorname{MoK} \alpha(\lambda=0.71073)$

$2 \Theta$ range for data collection/ ${ }^{\circ} 5.592$ to 52.732

Index ranges

Reflections collected

Independent reflections

Data/restraints/parameters

Goodness-of-fit on $\mathrm{F}^{2}$

Final R indexes [I $>=2 \sigma(\mathrm{I})]$

Final $\mathrm{R}$ indexes [all data]

Largest diff. peak/hole / e $\AA^{-3}$

Flack parameter
$-33 \leq \mathrm{h} \leq 18,-21 \leq \mathrm{k} \leq 18,-7 \leq 1 \leq 5$

2501

$1248\left[\mathrm{R}_{\text {int }}=0.0139, \mathrm{R}_{\text {sigma }}=0.0214\right]$

$1248 / 1 / 133$

1.084

$\mathrm{R}_{1}=0.0303, \mathrm{wR}_{2}=0.0716$

$\mathrm{R}_{1}=0.0326, \mathrm{wR}_{2}=0.0731$

$-0.6(8)$ 
Table S20. Fractional Atomic Coordinates $\left(\times 10^{4}\right)$ and Equivalent Isotropic Displacement Parameters $\left(\AA^{2} \times 10^{3}\right)$ for $6 . \mathrm{U}_{\text {eq }}$ is defined as $1 / 3$ of of the trace of the orthogonalised $\mathrm{U}_{\mathrm{IJ}}$ tensor.

$\begin{array}{lrrrr}\text { Atom } & \boldsymbol{x} & \boldsymbol{y} & \boldsymbol{z} & \mathbf{U}(\mathbf{e q}) \\ \text { C1 } & 5029.1(10) & 4560.1(13) & 11460(4) & 36.4(5) \\ \text { C2 } & 4549(1) & 8939(4) & 26.9(5) \\ \text { C3 } & 4943.4(7) & 4345.0(12) & 8513(4) & 33.0(5) \\ \text { C4 } & 4403.4(9) & 4009.5(11) & 7663(4) & 30.8(5) \\ \text { N1 } & 4065.4(12) & 5333(5) & 44.3(5) \\ \text { N2 } & 5282.7(9) & 2648.7(10) & 7940(5) & 43.4(6) \\ \text { O1 } & 3904.0(8) & 4496.2(8) & 6218(3) & 37.1(4) \\ \text { O2 } & 5446.9(8) & 4250.5(13) & 3484(4) & 64.5(6) \\ \text { O3 } & 4297.8(6) & 3570.3(12) & 6459(4) & 66.6(6) \\ \text { O4 } & 3270.3(7) & 8727(3) & 42.3(5) \\ \text { O5 } & 3806.9(9) & 2742.3(10) & 6437(5) & 61.7(6) \\ \text { O6 } & 3726.2(8) & 2069.3(9) & 8964(5) & 68.2(7)\end{array}$

Table S21. Anisotropic Displacement Parameters $\left(\AA^{2} \times 10^{3}\right)$ for Compound 6. The Anisotropic displacement factor exponent takes the form: $-2 \pi^{2}\left[h^{2} a^{* 2} U_{11}+2 h k a * b * U_{12}+\ldots\right]$.

\begin{tabular}{|c|c|c|c|c|c|c|}
\hline Atom & $\mathbf{U}_{11}$ & $\mathbf{U}_{22}$ & $\mathbf{U}_{33}$ & $\mathbf{U}_{23}$ & $\mathbf{U}_{13}$ & $\mathbf{U}_{12}$ \\
\hline $\mathrm{C} 1$ & $34.2(13)$ & $43.2(11)$ & $31.7(13)$ & $4.7(10)$ & $0.5(12)$ & $2.8(10)$ \\
\hline $\mathrm{C} 2$ & $24.4(10)$ & $26.9(9)$ & $29.3(11)$ & $3.1(9)$ & $0.4(10)$ & $0.6(7)$ \\
\hline $\mathrm{C} 3$ & $27.2(11)$ & $34.7(10)$ & $37.0(14)$ & $2.8(10)$ & $2.2(11)$ & $-3.1(9)$ \\
\hline $\mathrm{C} 4$ & $28.5(12)$ & $25.8(9)$ & $38.2(14)$ & 4.1(9) & $2.5(12)$ & $1.2(8)$ \\
\hline N1 & $27.9(10)$ & $50.6(11)$ & $54.3(15)$ & $-17.9(11)$ & $-2.3(11)$ & $-1.9(9)$ \\
\hline N2 & $34.0(11)$ & $31.0(9)$ & $65.4(16)$ & $-3.6(10)$ & $-4.0(12)$ & $3.2(7)$ \\
\hline $\mathrm{O} 1$ & $32.6(8)$ & $39.0(7)$ & $39.8(10)$ & $2.2(7)$ & $-8.3(8)$ & $-8.7(6)$ \\
\hline $\mathrm{O} 2$ & $53.0(13)$ & $84.0(13)$ & $56.6(14)$ & $-9.7(11)$ & $-24.4(12)$ & $2.1(10)$ \\
\hline $\mathrm{O} 3$ & $55.9(13)$ & $72.2(12)$ & $71.8(15)$ & $-12.8(12)$ & 7.3(13) & $-34.6(11)$ \\
\hline $\mathrm{O} 4$ & $45.9(9)$ & $27.2(6)$ & $53.7(12)$ & $4.2(7)$ & $12.5(10)$ & $5.0(6)$ \\
\hline $\mathrm{O} 5$ & $51.0(12)$ & $47.8(9)$ & $86.3(17)$ & $-10.3(11)$ & $23.8(14)$ & $5.9(8)$ \\
\hline O6 & $74.4(14)$ & $27.4(8)$ & $103.0(19)$ & $13.4(10)$ & $4.6(15)$ & $4.7(8)$ \\
\hline
\end{tabular}

Table S22. Bond Lengths for Compound 6.

Atom Atom Length/̊̊ Atom Atom Length $/ \AA$ 


$\begin{array}{llllll}\mathrm{C} 1 & \mathrm{C}^{1} & 1.531(5) & \mathrm{N} 1 & \mathrm{O} 1 & 1.405(3) \\ \mathrm{C} 1 & \mathrm{C} 2 & 1.549(3) & \mathrm{N} 1 & \mathrm{O} 2 & 1.197(4) \\ \mathrm{C} 2 & \mathrm{C} 2{ }^{1} & 1.591(3) & \mathrm{N} 1 & \mathrm{O} 3 & 1.197(3) \\ \mathrm{C} 2 & \mathrm{C} 3 & 1.522(3) & \mathrm{N} 2 & \mathrm{O} 4 & 1.384(3) \\ \mathrm{C} 2 & \mathrm{C} 4 & 1.520(3) & \mathrm{N} 2 & \mathrm{O} 5 & 1.183(3) \\ \mathrm{C} 3 & \mathrm{O} 1 & 1.447(3) & \mathrm{N} 2 & \mathrm{O} 6 & 1.202(3) \\ \mathrm{C} 4 & \mathrm{O} 4 & 1.461(2) & & & \\ & & & & & \end{array}$

Table S23. Bond Angles for Compound 6.

\begin{tabular}{|c|c|c|c|c|c|c|c|}
\hline \multicolumn{3}{|c|}{ Atom Atom Atom } & \multirow{2}{*}{$\begin{array}{l}\text { Angle/ }{ }^{\circ} \\
89.83(11)\end{array}$} & \multicolumn{3}{|c|}{ Atom Atom Atom } & \multirow{2}{*}{$\begin{array}{l}\text { Angle } /^{\circ} \\
112.5(2)\end{array}$} \\
\hline $\mathrm{C} 1^{1}$ & $\mathrm{C} 1$ & $\mathrm{C} 2$ & & $\mathrm{O} 2$ & N1 & $\mathrm{O} 1$ & \\
\hline $\mathrm{C} 1$ & $\mathrm{C} 2$ & $\mathrm{C} 2^{1}$ & $87.66(11)$ & $\mathrm{O} 2$ & N1 & $\mathrm{O} 3$ & $129.8(2)$ \\
\hline $\mathrm{C} 3$ & $\mathrm{C} 2$ & $\mathrm{C} 1$ & $108.28(19)$ & $\mathrm{O} 3$ & N1 & $\mathrm{O} 1$ & $117.7(3)$ \\
\hline $\mathrm{C} 3$ & $\mathrm{C} 2$ & $\mathrm{C} 2^{1}$ & $114.31(19)$ & $\mathrm{O5}$ & $\mathrm{N} 2$ & $\mathrm{O} 4$ & $119.1(2)$ \\
\hline $\mathrm{C} 4$ & $\mathrm{C} 2$ & $\mathrm{C} 1$ & $114.92(19)$ & O5 & $\mathrm{N} 2$ & O6 & $129.2(2)$ \\
\hline $\mathrm{C} 4$ & $\mathrm{C} 2$ & $\mathrm{C} 2^{1}$ & $119.14(18)$ & O6 & $\mathrm{N} 2$ & $\mathrm{O} 4$ & $111.7(2)$ \\
\hline $\mathrm{C} 4$ & $\mathrm{C} 2$ & $\mathrm{C} 3$ & $110.38(19)$ & N1 & $\mathrm{O} 1$ & $\mathrm{C} 3$ & 114.93(19) \\
\hline $\mathrm{O} 1$ & C3 & $\mathrm{C} 2$ & $108.07(19)$ & $\mathrm{N} 2$ & $\mathrm{O} 4$ & $\mathrm{C} 4$ & $115.18(19)$ \\
\hline $\mathrm{O} 4$ & $\mathrm{C} 4$ & $\mathrm{C} 2$ & $101.25(18)$ & & & & \\
\hline
\end{tabular}

Table S24. Torsion Angles for Compound 6.

\begin{tabular}{|c|c|c|c|}
\hline $\begin{array}{llll}A & B & C & D\end{array}$ & Angle $/^{\circ}$ & $\begin{array}{llll}\mathbf{A} & \mathbf{B} & \mathbf{C} & \mathbf{D}\end{array}$ & Angle $/^{\circ}$ \\
\hline $\mathrm{C} 1^{1} \mathrm{C} 1 \mathrm{C} 2 \mathrm{C} 2^{1}$ & $16.8(2)$ & $\mathrm{C} 2 \mathrm{C} 4 \mathrm{O} 4 \mathrm{~N} 2$ & $-178.44(18)$ \\
\hline $\mathrm{C} 1{ }^{1} \mathrm{C} 1 \mathrm{C} 2 \mathrm{C} 3$ & $-98.1(2)$ & $\mathrm{C} 3 \mathrm{C} 2 \mathrm{C} 4 \mathrm{O} 4$ & $-65.4(2)$ \\
\hline $\mathrm{C} 1{ }^{1} \mathrm{C} 1 \mathrm{C} 2 \mathrm{C} 4$ & $138.0(2)$ & $\mathrm{C} 4 \mathrm{C} 2 \mathrm{C} 3 \mathrm{O} 1$ & $-65.5(2)$ \\
\hline $\mathrm{C} 1 \mathrm{C} 2 \mathrm{C} 3 \mathrm{O} 1$ & $167.88(17)$ & $\mathrm{O} 2 \mathrm{~N} 1 \mathrm{O} 1 \mathrm{C} 3$ & $174.8(2)$ \\
\hline $\mathrm{C} 1 \mathrm{C} 2 \mathrm{C} 4 \mathrm{O} 4$ & $57.4(2)$ & O3 N1 O1 C3 & $-7.0(3)$ \\
\hline $\mathrm{C} 2{ }^{1} \mathrm{C} 2 \mathrm{C} 3 \mathrm{O} 1$ & $72.03(17)$ & $\mathrm{O} 5 \mathrm{~N} 2 \mathrm{O} 4 \mathrm{C} 4$ & $-3.5(3)$ \\
\hline $\mathrm{C} 2^{1} \mathrm{C} 2 \mathrm{C} 4 \mathrm{O} 4$ & $159.36(15)$ & $\mathrm{O} 6 \mathrm{~N} 2 \mathrm{O} 4 \mathrm{C} 4$ & $176.3(2)$ \\
\hline C2 C3O1N1 & $155.07(17)$ & & \\
\hline
\end{tabular}

${ }^{1} 1-X, 1-Y,+Z$ 


\section{Compound 7}

CCDC 1935557

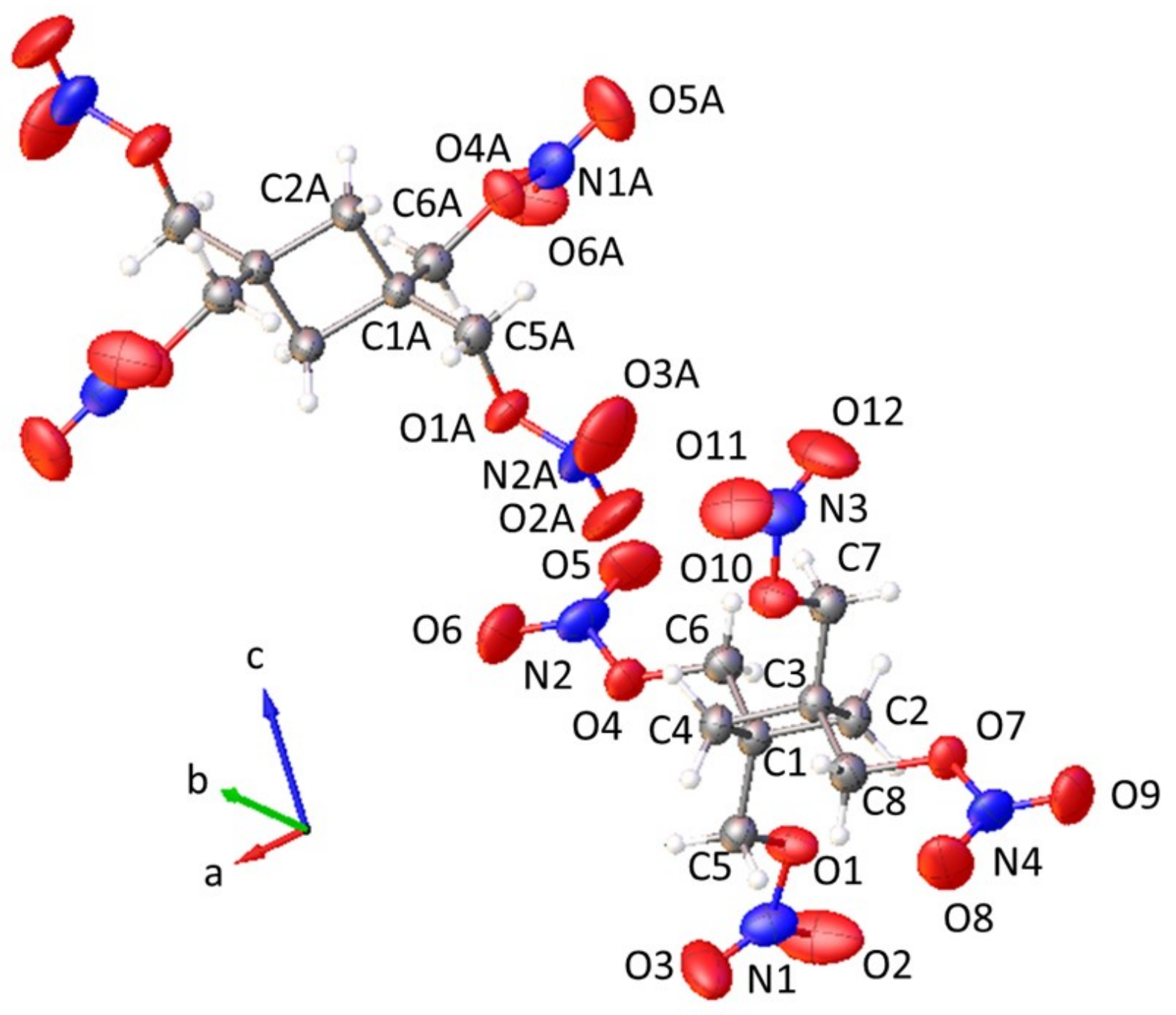

Figure S5. Molecular conformation and atom-numbering scheme for Compound 7. Non-labeled atoms are generated by inversion (two - x, $1-\mathrm{y}, 2-\mathrm{z}$ ). Non-hydrogen atoms are shown as 50\% probability displacement ellipsoids. 
Table S25. Crystal data and structure refinement for Compound 7.

\begin{tabular}{|c|c|}
\hline Empirical formula & $\mathrm{C}_{8} \mathrm{H}_{12} \mathrm{~N}_{4} \mathrm{O}_{12}$ \\
\hline Formula weight & 356.22 \\
\hline Temperature/K & $298.00(10)$ \\
\hline Crystal system & monoclinic \\
\hline Space group & $\mathrm{P} 2{ }_{1} / \mathrm{n}$ \\
\hline $\mathrm{a} / \AA$ & $6.2457(2)$ \\
\hline $\mathrm{b} / \AA$ & $23.7522(7)$ \\
\hline $\mathrm{c} / \AA$ & $15.0056(4)$ \\
\hline$\alpha /^{\circ}$ & 90 \\
\hline$\beta /{ }^{\circ}$ & $93.400(3)$ \\
\hline$\gamma /{ }^{\circ}$ & 90 \\
\hline Volume $/ \AA^{3}$ & $2222.15(11)$ \\
\hline $\mathrm{Z}$ & 6 \\
\hline$\rho_{\text {calc }} \mathrm{g} / \mathrm{cm}^{3}$ & 1.597 \\
\hline$\mu / \mathrm{mm}^{-1}$ & 0.153 \\
\hline $\mathrm{F}(000)$ & 1104.0 \\
\hline Crystal size $/ \mathrm{mm}^{3}$ & $0.35 \times 0.24 \times 0.23$ \\
\hline Radiation & $\operatorname{MoK} \alpha(\lambda=0.71073)$ \\
\hline \multicolumn{2}{|c|}{$2 \Theta$ range for data collection $/{ }^{\circ} 3.214$ to 52.74} \\
\hline Index ranges & $-7 \leq \mathrm{h} \leq 7,-29 \leq \mathrm{k} \leq 29,-18 \leq 1 \leq 18$ \\
\hline Reflections collected & 18585 \\
\hline Independent reflections & $4544\left[R_{\text {int }}=0.0235, R_{\text {sigma }}=0.0192\right]$ \\
\hline Data/restraints/parameters & $4544 / 0 / 397$ \\
\hline Goodness-of-fit on $\mathrm{F}^{2}$ & 1.041 \\
\hline Final $\mathrm{R}$ indexes $[\mathrm{I}>=2 \sigma(\mathrm{I})]$ & $\mathrm{R}_{1}=0.0421, \mathrm{wR}_{2}=0.0937$ \\
\hline Final R indexes [all data] & $\mathrm{R}_{1}=0.0554, \mathrm{wR}_{2}=0.1005$ \\
\hline Largest diff. peak/hole / e $\AA^{-}$ & $0.20 /-0.33$ \\
\hline
\end{tabular}


Table S26. Fractional Atomic Coordinates $\left(\times 10^{4}\right)$ and Equivalent Isotropic Displacement Parameters $\left(\AA^{2} \times 10^{3}\right)$ for 7 . $U_{\text {eq }}$ is defined as $1 / 3$ of the trace of the orthogonalised $U_{\text {IJ }}$ tensor.

\begin{tabular}{|c|c|c|c|c|}
\hline Atom & $x$ & $\boldsymbol{y}$ & $\boldsymbol{z}$ & $\mathbf{U}(\mathbf{e q})$ \\
\hline $\mathrm{O} 1$ & $6723(2)$ & $2096.2(5)$ & $4268.1(8)$ & $45.9(3)$ \\
\hline $\mathrm{O} 2$ & $7714(4)$ & $1302.9(6)$ & $3722.7(13)$ & $98.0(7)$ \\
\hline $\mathrm{O} 3$ & $9700(3)$ & $2024.1(8)$ & $3538.4(14)$ & $85.9(6)$ \\
\hline $\mathrm{O} 4$ & $8507.6(18)$ & $2861.3(5)$ & $6123.8(7)$ & $42.3(3)$ \\
\hline O5 & 8145(3) & $2408.8(8)$ & $7394.9(10)$ & $73.8(5)$ \\
\hline O6 & $11143(3)$ & $2817.0(8)$ & 7119(1) & $79.4(5)$ \\
\hline O7 & $532.5(17)$ & $3669.8(5)$ & $3569.6(7)$ & $39.3(3)$ \\
\hline O8 & 701(3) & $4176.5(8)$ & $2339.6(10)$ & $77.2(5)$ \\
\hline O9 & $-2210(2)$ & $3743.2(7)$ & $2633.9(10)$ & $70.5(5)$ \\
\hline $\mathrm{O} 10$ & $2514(2)$ & $4453.5(5)$ & $5396.6(8)$ & $44.4(3)$ \\
\hline O11 & $1747(3)$ & $5261.6(7)$ & $5946.2(12)$ & $85.4(5)$ \\
\hline $\mathrm{O} 12$ & 212(3) & $4530.0(8)$ & $6450.4(14)$ & $91.8(6)$ \\
\hline N1 & $8206(3)$ & $1784.0(7)$ & $3808(1)$ & $51.4(4)$ \\
\hline N2 & $9309(3)$ & $2678.5(8)$ & $6957.3(10)$ & $54.0(4)$ \\
\hline N3 & $1375(3)$ & $4770.3(7)$ & $5988.1(12)$ & $55.5(4)$ \\
\hline N4 & $-378(3)$ & $3883.1(7)$ & $2774.9(10)$ & $48.8(4)$ \\
\hline $\mathrm{C} 1$ & $5782(2)$ & $2948.2(6)$ & $4981.7(10)$ & $29.9(3)$ \\
\hline $\mathrm{C} 2$ & $3331(3)$ & $2946.1(7)$ & $4731.0(12)$ & $33.2(4)$ \\
\hline $\mathrm{C} 3$ & $3324(2)$ & $3599.5(6)$ & $4688.3(10)$ & $29.5(3)$ \\
\hline $\mathrm{C} 4$ & $5782(2)$ & $3602.2(7)$ & $4919.8(12)$ & $32.3(3)$ \\
\hline $\mathrm{C} 5$ & $7167(3)$ & $2693.6(7)$ & $4294.9(11)$ & $33.6(4)$ \\
\hline C6 & $6277(3)$ & $2714.6(8)$ & $5908.2(11)$ & $35.9(4)$ \\
\hline $\mathrm{C} 7$ & 2019(3) & $3857.3(7)$ & $5402.2(12)$ & $34.9(4)$ \\
\hline $\mathrm{C} 8$ & $2749(3)$ & $3839.5(8)$ & $3770.8(11)$ & $36.4(4)$ \\
\hline $\mathrm{O} 1 \mathrm{~A}$ & $7576(2)$ & $4333.0(6)$ & $8340.3(8)$ & $52.4(3)$ \\
\hline $\mathrm{O} 2 \mathrm{~A}$ & $6342(4)$ & $3916.2(10)$ & $7141.1(11)$ & $103.6(7)$ \\
\hline $\mathrm{O} 3 \mathrm{~A}$ & $4966(4)$ & $4718.4(11)$ & 7491.2(13) & $111.5(8)$ \\
\hline O4A & $6355.2(18)$ & $4121.0(5)$ & $10466.9(8)$ & $43.6(3)$ \\
\hline $\mathrm{O} 5 \mathrm{~A}$ & $3886(3)$ & $3632.5(7)$ & $11047.3(12)$ & $80.2(5)$ \\
\hline O6A & $6856(3)$ & $3223.4(6)$ & $10789.7(12)$ & $83.3(6)$ \\
\hline $\mathrm{N} 1 \mathrm{~A}$ & $6151(4)$ & $4330.6(11)$ & $7592.7(12)$ & $72.9(6)$ \\
\hline $\mathrm{N} 2 \mathrm{~A}$ & $5664(3)$ & $3611.5(7)$ & $10790.6(10)$ & $50.5(4)$ \\
\hline C1A & $8803(2)$ & $4688.7(6)$ & $9746(1)$ & $30.2(3)$ \\
\hline $\mathrm{C} 2 \mathrm{~A}$ & $8815(3)$ & $5184.7(8)$ & $10420.0(12)$ & $35.6(4)$ \\
\hline $\mathrm{C} 5 \mathrm{~A}$ & $7241(3)$ & $4789.9(8)$ & 8954.3(11) & $37.9(4)$ \\
\hline C6A & $8512(3)$ & $4114.6(7)$ & $10151.5(12)$ & $35.9(4)$ \\
\hline
\end{tabular}


Table S27. Anisotropic Displacement Parameters $\left(\AA^{2} \times 10^{3}\right)$ for Compound 7. The Anisotropic displacement factor exponent takes the form: $-2 \pi^{2}\left[h^{2} a^{* 2} U_{11}+2 h k a * b * U_{12}+\ldots\right]$.

\begin{tabular}{|c|c|c|c|c|c|c|}
\hline Atom & $\mathbf{U}_{11}$ & $\mathbf{U}_{22}$ & $\mathbf{U}_{33}$ & $\mathbf{U}_{23}$ & $\mathbf{U}_{13}$ & $\mathbf{U}_{12}$ \\
\hline $\mathrm{O} 1$ & $61.1(8)$ & $30.8(6)$ & $47.7(7)$ & $-1.5(5)$ & $19.4(6)$ & $2.3(5)$ \\
\hline $\mathrm{O} 2$ & $170(2)$ & $31.2(9)$ & $99.4(14)$ & $0.1(9)$ & $61.1(13)$ & $12(1)$ \\
\hline $\mathrm{O} 3$ & $50.3(9)$ & $90.0(13)$ & $119.9(15)$ & $-45.2(11)$ & 26.1(9) & $-3.0(9)$ \\
\hline $\mathrm{O} 4$ & $40.8(6)$ & $54.6(8)$ & $30.3(6)$ & $7.8(5)$ & $-8.5(5)$ & $0.5(5)$ \\
\hline O5 & $89.4(12)$ & $94.8(13)$ & $36.6(8)$ & $21.3(8)$ & $-1.2(8)$ & $4.2(10)$ \\
\hline O6 & $62.5(10)$ & $117.4(15)$ & $54.4(9)$ & $1.2(9)$ & $-29.5(8)$ & $0.4(9)$ \\
\hline $\mathrm{O} 7$ & $36.8(6)$ & 47.2(7) & $32.8(6)$ & $10.2(5)$ & $-7.0(5)$ & $-1.5(5)$ \\
\hline O8 & $75.3(10)$ & $113.5(14)$ & $42.0(8)$ & $36.3(9)$ & $-2.5(7)$ & $-15.3(10)$ \\
\hline O9 & $52.9(9)$ & $102.6(13)$ & $52.9(9)$ & $12.7(8)$ & $-22.0(7)$ & $-9.2(8)$ \\
\hline $\mathrm{O} 10$ & $55.7(7)$ & $30.6(6)$ & $48.1(7)$ & $-3.4(5)$ & $12.1(6)$ & $1.6(5)$ \\
\hline O11 & $125.3(15)$ & $35.6(9)$ & $96.4(13)$ & $-10.6(8)$ & $17.2(11)$ & $13.6(9)$ \\
\hline $\mathrm{O} 12$ & $101.8(14)$ & $76.2(12)$ & $103.9(14)$ & $-24.7(11)$ & $60.7(12)$ & $-6.4(10)$ \\
\hline N1 & 69.1(11) & $42.2(10)$ & 42.9(9) & $-1.1(7)$ & $4.1(8)$ & $17.2(8)$ \\
\hline N2 & $64.5(11)$ & $66.3(11)$ & $29.9(8)$ & $1.7(8)$ & $-9.6(8)$ & $11.6(9)$ \\
\hline N3 & $62.8(11)$ & $45.7(10)$ & $58.2(11)$ & $-10.9(8)$ & $6.1(9)$ & $12.2(8)$ \\
\hline N4 & 51.5(9) & $64.7(11)$ & $29.3(8)$ & $8.0(7)$ & $-5.7(7)$ & $2.0(8)$ \\
\hline $\mathrm{C} 1$ & $30.1(8)$ & 28.9(8) & $30.3(8)$ & $0.9(6)$ & $-1.7(6)$ & $-0.2(6)$ \\
\hline $\mathrm{C} 2$ & $31.5(8)$ & $29.6(8)$ & $38.0(9)$ & $0.3(7)$ & $-2.3(7)$ & $-2.2(6)$ \\
\hline $\mathrm{C} 3$ & $29.4(7)$ & $27.5(8)$ & $31.3(8)$ & $1.3(6)$ & $-1.0(6)$ & $-1.1(6)$ \\
\hline $\mathrm{C} 4$ & $30.8(8)$ & $30.5(9)$ & $35.2(9)$ & $-1.0(7)$ & $-2.1(7)$ & $-2.7(6)$ \\
\hline $\mathrm{C} 5$ & $36.1(9)$ & $31.9(8)$ & $32.4(9)$ & $0.1(7)$ & $-0.2(7)$ & $-2.2(7)$ \\
\hline C6 & $36.5(9)$ & $38.5(10)$ & $32.4(9)$ & $2.3(7)$ & $0.2(7)$ & $0.6(7)$ \\
\hline $\mathrm{C} 7$ & $35.8(9)$ & $33.5(9)$ & $35.4(9)$ & $0.7(7)$ & $1.8(7)$ & $-2.1(7)$ \\
\hline $\mathrm{C} 8$ & $34.6(8)$ & $40.6(10)$ & $33.9(9)$ & $3.9(7)$ & $-0.1(7)$ & $-1.6(7)$ \\
\hline O1A & $59.3(8)$ & 64.1(9) & $32.7(6)$ & $-11.7(6)$ & $-6.6(6)$ & $-7.8(7)$ \\
\hline $\mathrm{O} 2 \mathrm{~A}$ & $140.7(18)$ & $125.0(17)$ & $44.5(9)$ & $-32.0(11)$ & $0.7(10)$ & $-55.5(14)$ \\
\hline $\mathrm{O} 3 \mathrm{~A}$ & $115.5(17)$ & $137(2)$ & $74.9(13)$ & $12.7(13)$ & $-53.6(12)$ & $0.4(15)$ \\
\hline O4A & $39.4(6)$ & $36.1(7)$ & $55.9(8)$ & $12.6(6)$ & $7.3(5)$ & $-4.1(5)$ \\
\hline O5A & $59.8(10)$ & $84.8(12)$ & $97.4(13)$ & $26.5(10)$ & $16.0(9)$ & $-26.4(8)$ \\
\hline O6A & $123.6(15)$ & $31.6(8)$ & $98.5(13)$ & $6.3(8)$ & $39.4(11)$ & $2.8(9)$ \\
\hline N1A & $82.9(15)$ & $100.7(17)$ & $33.4(9)$ & $-0.3(11)$ & $-9.2(9)$ & $-37.4(13)$ \\
\hline $\mathrm{N} 2 \mathrm{~A}$ & $65.5(11)$ & $41.4(10)$ & $44.5(9)$ & $3.5(7)$ & $2.8(8)$ & $-17.7(8)$ \\
\hline $\mathrm{C} 1 \mathrm{~A}$ & $28.0(7)$ & $32.5(8)$ & $30.1(8)$ & $-4.0(6)$ & $1.0(6)$ & $-3.5(6)$ \\
\hline $\mathrm{C} 2 \mathrm{~A}$ & $30.4(8)$ & $39.3(10)$ & $37.3(9)$ & $-9.4(8)$ & $4.5(7)$ & $-4.0(7)$ \\
\hline C5A & $39.0(9)$ & $40.1(10)$ & $34.1(9)$ & $2.4(8)$ & $-2.1(7)$ & $-4.9(7)$ \\
\hline C6A & $36.2(9)$ & $36.3(9)$ & $35.0(9)$ & $-0.4(7)$ & $2.4(7)$ & $1.7(7)$ \\
\hline
\end{tabular}


Table S28. Bond Lengths for Compound 7.

\begin{tabular}{|c|c|c|c|c|c|}
\hline \multicolumn{2}{|c|}{ Atom Atom } & Length/Å & \multicolumn{2}{|c|}{ Atom Atom } & Length/Å \\
\hline $\mathrm{O} 1$ & N1 & $1.4002(19)$ & $\mathrm{C} 1$ & C6 & $1.512(2)$ \\
\hline $\mathrm{O} 1$ & $\mathrm{C} 5$ & $1.4457(19)$ & $\mathrm{C} 2$ & $\mathrm{C} 3$ & $1.553(2)$ \\
\hline $\mathrm{O} 2$ & N1 & $1.188(2)$ & $\mathrm{C} 3$ & $\mathrm{C} 4$ & $1.554(2)$ \\
\hline $\mathrm{O} 3$ & N1 & $1.185(2)$ & $\mathrm{C} 3$ & $\mathrm{C} 7$ & $1.514(2)$ \\
\hline $\mathrm{O} 4$ & N2 & $1.3891(18)$ & C3 & $\mathrm{C} 8$ & $1.513(2)$ \\
\hline $\mathrm{O} 4$ & C6 & $1.454(2)$ & O1A & N1A & $1.390(2)$ \\
\hline $\mathrm{O} 5$ & N2 & $1.195(2)$ & O1A & $\mathrm{C} 5 \mathrm{~A}$ & $1.447(2)$ \\
\hline O6 & N2 & $1.203(2)$ & $\mathrm{O} 2 \mathrm{~A}$ & $\mathrm{~N} 1 \mathrm{~A}$ & $1.205(3)$ \\
\hline $\mathrm{O} 7$ & N4 & $1.3862(17)$ & $\mathrm{O} 3 \mathrm{~A}$ & N1A & $1.186(3)$ \\
\hline $\mathrm{O} 7$ & $\mathrm{C} 8$ & $1.4564(19)$ & $\mathrm{O} 4 \mathrm{~A}$ & $\mathrm{~N} 2 \mathrm{~A}$ & $1.3827(19)$ \\
\hline $\mathrm{O} 8$ & N4 & $1.191(2)$ & $\mathrm{O} 4 \mathrm{~A}$ & C6A & $1.454(2)$ \\
\hline O9 & N4 & $1.198(2)$ & $\mathrm{O} 5 \mathrm{~A}$ & $\mathrm{~N} 2 \mathrm{~A}$ & $1.198(2)$ \\
\hline $\mathrm{O} 10$ & N3 & $1.391(2)$ & O6A & $\mathrm{N} 2 \mathrm{~A}$ & $1.185(2)$ \\
\hline $\mathrm{O} 10$ & $\mathrm{C} 7$ & $1.450(2)$ & C1A & $\mathrm{C} 2 \mathrm{~A}$ & $1.552(2)$ \\
\hline O11 & N3 & $1.192(2)$ & $\mathrm{C} 1 \mathrm{~A}$ & $\mathrm{C} 2 \mathrm{~A}^{1}$ & $1.552(2)$ \\
\hline $\mathrm{O} 12$ & N3 & $1.181(2)$ & C1A & C5A & $1.511(2)$ \\
\hline $\mathrm{C} 1$ & $\mathrm{C} 2$ & $1.554(2)$ & C1A & C6A & $1.509(2)$ \\
\hline $\mathrm{C} 1$ & $\mathrm{C} 4$ & $1.556(2)$ & $\mathrm{C} 2 \mathrm{~A}$ & $\mathrm{C} 1 \mathrm{~A}^{1}$ & $1.552(2)$ \\
\hline $\mathrm{C} 1$ & $\mathrm{C} 5$ & $1.511(2)$ & & & \\
\hline
\end{tabular}


Table S29. Bond Angles for Compound 7.

Atom Atom Atom

N1 O1 C5

$\mathrm{N} 2 \quad \mathrm{O} 4 \quad \mathrm{C} 6$

$\mathrm{N} 4 \quad \mathrm{O} 7 \quad \mathrm{C} 8$

N3 $\quad \mathrm{O} 10 \quad \mathrm{C} 7$

O2 $\mathrm{N} 1 \quad \mathrm{O} 1$

O3 N1 O1

O3 $\mathrm{N} 1 \quad \mathrm{O} 2$

O5 $\mathrm{N} 2 \quad \mathrm{O} 4$

O5 N2 O6

O6 $\mathrm{N} 2 \quad \mathrm{O} 4$

O11 N3 O10

O12 N3 O10

O12 N3 O11

O8 $\mathrm{N} 4 \quad \mathrm{O} 7$

O8 N4 O9

O9 $\mathrm{N} 4 \quad \mathrm{O} 7$

C2 $\mathrm{C} 1 \quad \mathrm{C} 4$

C5 $\mathrm{C} 1 \quad \mathrm{C} 2$

C5 $\mathrm{C} 1 \quad \mathrm{C} 4$

C5 $\mathrm{C} 1 \quad \mathrm{C} 6$

C6 61 C2

C6 $\mathrm{C} 1 \quad \mathrm{C} 4$

C3 $\mathrm{C} 2 \quad \mathrm{C} 1$

$\mathrm{C} 2 \quad \mathrm{C} 3 \quad \mathrm{C} 4$

C7 $\quad \mathrm{C} 3 \quad \mathrm{C} 2$

C7 $\quad$ C3 34

${ }^{1} 2-X, 1-Y, 2-Z$

\section{Angle $/^{\circ}$}

113.71(13)

114.52(13)

114.43(12)

114.06(14)

112.82(18)

118.08(16)

129.06(19)

117.64(16)

129.74(17)

112.60(17)

$112.80(18)$

117.96(17)

129.24(19)

117.96(15)

129.12(16)

112.92(15)

$89.57(11)$

115.42(13)

$110.90(13)$

112.72(13)

111.49(13)

$114.86(14)$

90.40(11)

$89.69(11)$

112.04(13)

113.99(13)
Atom Atom Atom

C7 $\quad$ C3 3 C8

C8 $\quad$ C3 32

C8 $\quad$ C3 34

C3 $34 \quad \mathrm{C} 1$

O1 C5 C1

O4 C6 C1

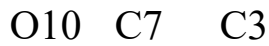

O7 $\mathrm{C} 8 \quad \mathrm{C} 3$

N1A O1A C5A

N2A O4A C6A

O2A N1A O1A

O3A N1A O1A

O3A N1A O2A

O5A N2A O4A

O6A N2A O4A

O6A N2A O5A

C2A C1A C2A ${ }^{1}$

C5A C1A C2A

C5A C1A C2A ${ }^{1}$

C6A C1A C2A

C6A C1A C2A ${ }^{1}$

C6A C1A C5A

C1A C2A C1A ${ }^{1}$

O1A C5A C1A

O4A C6A C1A
Angle ${ }^{\circ}$

112.51(13)

114.44(14)

$112.32(13)$

90.32(11)

107.17(13)

104.94(13)

105.50(13)

104.81(13)

114.03(16)

114.82(13)

112.2(2)

$117.7(2)$

130.1(2)

113.02(17)

118.11(17)

128.87(18)

$89.42(12)$

$111.69(14)$

115.04(14)

$114.78(14)$

$112.28(13)$

111.92(13)

90.57(12)

105.69(13)

104.95(12) 
Table S30. Torsion Angles for Compound 7.

\begin{tabular}{|c|c|c|c|c|c|c|c|}
\hline A B & C D & Angle ${ }^{\circ}$ & $\mathbf{A}$ & B & C & D & Angle ${ }^{\circ}$ \\
\hline N1 O1 & $\mathrm{C} 5 \mathrm{C} 1$ & $-166.92(13)$ & C6 & $\mathrm{C} 1$ & $\mathrm{C} 4$ & $\mathrm{C} 3$ & $-112.51(14)$ \\
\hline $\mathrm{N} 2 \mathrm{O} 4$ & $\mathrm{C} 6 \mathrm{C} 1$ & $-179.40(13)$ & C6 & $\mathrm{C} 1$ & $\mathrm{C} 5$ & $\mathrm{O} 1$ & $61.53(17)$ \\
\hline N3O1C & $\mathrm{C} 7 \mathrm{C} 3$ & $177.15(13)$ & $\mathrm{C} 7$ & $\mathrm{O} 10$ & N3 & O11 & $-177.23(16)$ \\
\hline N4 O7 & $\mathrm{C} 8 \mathrm{C} 3$ & $175.52(13)$ & $\mathrm{C} 7$ & $\mathrm{O} 10$ & N3 & $\mathrm{O} 12$ & $2.8(2)$ \\
\hline $\mathrm{C} 1 \mathrm{C} 2$ & $\mathrm{C} 3 \mathrm{C} 4$ & $1.08(13)$ & $\mathrm{C} 7$ & $\mathrm{C} 3$ & $\mathrm{C} 4$ & $\mathrm{C} 1$ & $113.02(14)$ \\
\hline $\mathrm{C} 1 \mathrm{C} 2$ & C3 C7 & $-114.80(14)$ & $\mathrm{C} 7$ & $\mathrm{C} 3$ & $\mathrm{C} 8$ & $\mathrm{O} 7$ & $-64.51(17)$ \\
\hline $\mathrm{C} 1 \mathrm{C} 2$ & C3 C8 & $115.58(14)$ & C8 & $\mathrm{O} 7$ & N4 & O8 & $0.1(2)$ \\
\hline $\mathrm{C} 2 \mathrm{C} 1$ & $\mathrm{C} 4 \mathrm{C} 3$ & $1.08(13)$ & $\mathrm{C} 8$ & O7 & $\mathrm{N} 4$ & O9 & $-178.97(16)$ \\
\hline $\mathrm{C} 2 \mathrm{C} 1$ & C5 O1 & $-68.16(17)$ & C8 & $\mathrm{C} 3$ & $\mathrm{C} 4$ & $\mathrm{C} 1$ & $-117.51(14)$ \\
\hline $\mathrm{C} 2 \mathrm{C} 1$ & C6 O4 & $-167.31(13)$ & $\mathrm{C} 8$ & C3 & $\mathrm{C} 7$ & $\mathrm{O} 10$ & $-60.65(16)$ \\
\hline $\mathrm{C} 2 \mathrm{C} 3$ & $\mathrm{C} 4 \mathrm{C} 1$ & $-1.08(13)$ & N1A & $\mathrm{O} 1 \mathrm{~A}$ & AC5A & $\mathrm{C} 1 \mathrm{~A}$ & $175.30(14)$ \\
\hline $\mathrm{C} 2 \mathrm{C} 3$ & C7 O10 & $168.74(12)$ & $\mathrm{N} 2 \mathrm{~A}$ & $\mathrm{O} 4 \mathrm{~A}$ & A C6A & $\mathrm{C} 1 \mathrm{~A}$ & $174.04(13)$ \\
\hline $\mathrm{C} 2 \mathrm{C} 3$ & $\mathrm{C} 8 \mathrm{O} 7$ & $64.88(17)$ & $\mathrm{C} 2 \mathrm{~A}$ & ${ }^{1} \mathrm{C} 1 \mathrm{~A}$ & $\mathrm{AC} 2 \mathrm{~A}$ & $\mathrm{C} \mathrm{A}^{1}$ & $0.000(1)$ \\
\hline $\mathrm{C} 4 \mathrm{C} 1$ & $\mathrm{C} 2 \mathrm{C} 3$ & $-1.08(13)$ & $\mathrm{C} 2 \mathrm{~A}$ & ${ }^{1} \mathrm{C} 1 \mathrm{~A}$ & $\mathrm{AC} 5 \mathrm{~A}$ & O1A & $73.52(17)$ \\
\hline $\mathrm{C} 4 \mathrm{C} 1$ & $\mathrm{C} 5 \mathrm{O} 1$ & $-168.09(12)$ & $\mathrm{C} 2 \mathrm{~A}$ & $\mathrm{C} 1 \mathrm{~A}$ & $\mathrm{AC} 5 \mathrm{~A}$ & O1A & $173.53(13)$ \\
\hline $\mathrm{C} 4 \mathrm{C} 1$ & C6 O4 & $-67.32(17)$ & $\mathrm{C} 2 \mathrm{~A}$ & ${ }^{1} \mathrm{C} 1 \mathrm{~A}$ & $\mathrm{AC} 6 \mathrm{~A}$ & $\mathrm{O} 4 \mathrm{~A}$ & $166.03(13)$ \\
\hline $\mathrm{C} 4 \mathrm{C} 3$ & C7 O10 & $68.73(16)$ & $\mathrm{C} 2 \mathrm{~A}$ & $\mathrm{C} 1 \mathrm{~A}$ & A C6A & O4A & $65.82(16)$ \\
\hline $\mathrm{C} 4 \mathrm{C} 3$ & $\mathrm{C} 8 \mathrm{O} 7$ & $165.26(13)$ & C5A & $\mathrm{O} 1 \mathrm{~A}$ & AN1A & $\mathrm{AO} 2 \mathrm{~A}$ & $-173.32(17)$ \\
\hline $\mathrm{C} 5 \mathrm{O} 1$ & $\mathrm{~N} 1 \mathrm{O} 2$ & $-173.64(17)$ & C5A & $\mathrm{O} 1 \mathrm{~A}$ & AN1A & $\mathrm{AO} A \mathrm{~A}$ & $6.6(3)$ \\
\hline $\mathrm{C} 5 \mathrm{O} 1$ & N1 O3 & $4.2(2)$ & C5A & $\mathrm{C} 1 \mathrm{~A}$ & $\mathrm{AC} 2 \mathrm{~A}$ & $\mathrm{ClA}^{1}$ & $-116.84(16)$ \\
\hline $\mathrm{C} 5 \mathrm{C} 1$ & $\mathrm{C} 2 \mathrm{C} 3$ & $-114.12(14)$ & C5A & $\mathrm{C} 1 \mathrm{~A}$ & А C6A & O4A & $-62.83(17)$ \\
\hline $\mathrm{C} 5 \mathrm{C} 1$ & C4 C3 & $118.25(13)$ & C6A & $\mathrm{O} 4 \mathrm{~A}$ & $\mathrm{AN} 2$ & $\mathrm{AO} 5 \mathrm{~A}$ & $179.76(16)$ \\
\hline $\mathrm{C} 5 \mathrm{C} 1$ & C6 O4 & 61.01(17) & C6A & $\mathrm{O} 4 \mathrm{~A}$ & $\mathrm{AN} 2$ & A O6A & $0.4(2)$ \\
\hline $\mathrm{C} 6 \mathrm{O} 4$ & $\mathrm{~N} 2 \mathrm{O} 5$ & $2.4(2)$ & C6A & $\mathrm{C} 1 \mathrm{~A}$ & $\mathrm{AC} 2 \mathrm{~A}$ & $\mathrm{C} 1 \mathrm{~A}^{1}$ & $114.39(15)$ \\
\hline $\mathrm{C} 6 \mathrm{O} 4$ & N2O6 & $-178.63(16)$ & C6A & $\mathrm{C} 1 \mathrm{~A}$ & A C $5 A$ & O1A & $-56.21(18)$ \\
\hline $\mathrm{C} 6 \mathrm{C} 1$ & C2 C3 & $115.59(14)$ & & & & & \\
\hline
\end{tabular}

\section{Special Details}

Geometry. All experimental estimated standard deviations (esds) are estimated using the full covariance matrix. The cell esds are taken into account individually in the estimation of esds in distances and angles; correlations between esds in cell parameters are only used when they are defined by crystal symmetry. An approximate (isotropic) treatment of cell esds is used for estimating esds involving 1.s. planes. 


\section{NMR Spectra}

Compound $8{ }^{1} \mathrm{H}$ NMR

$\mathrm{MeO}_{2} \mathrm{C} " \mathrm{MeO}^{\mathrm{M}_{2} \mathrm{C}} \mathrm{CO}_{2} \mathrm{Me}$

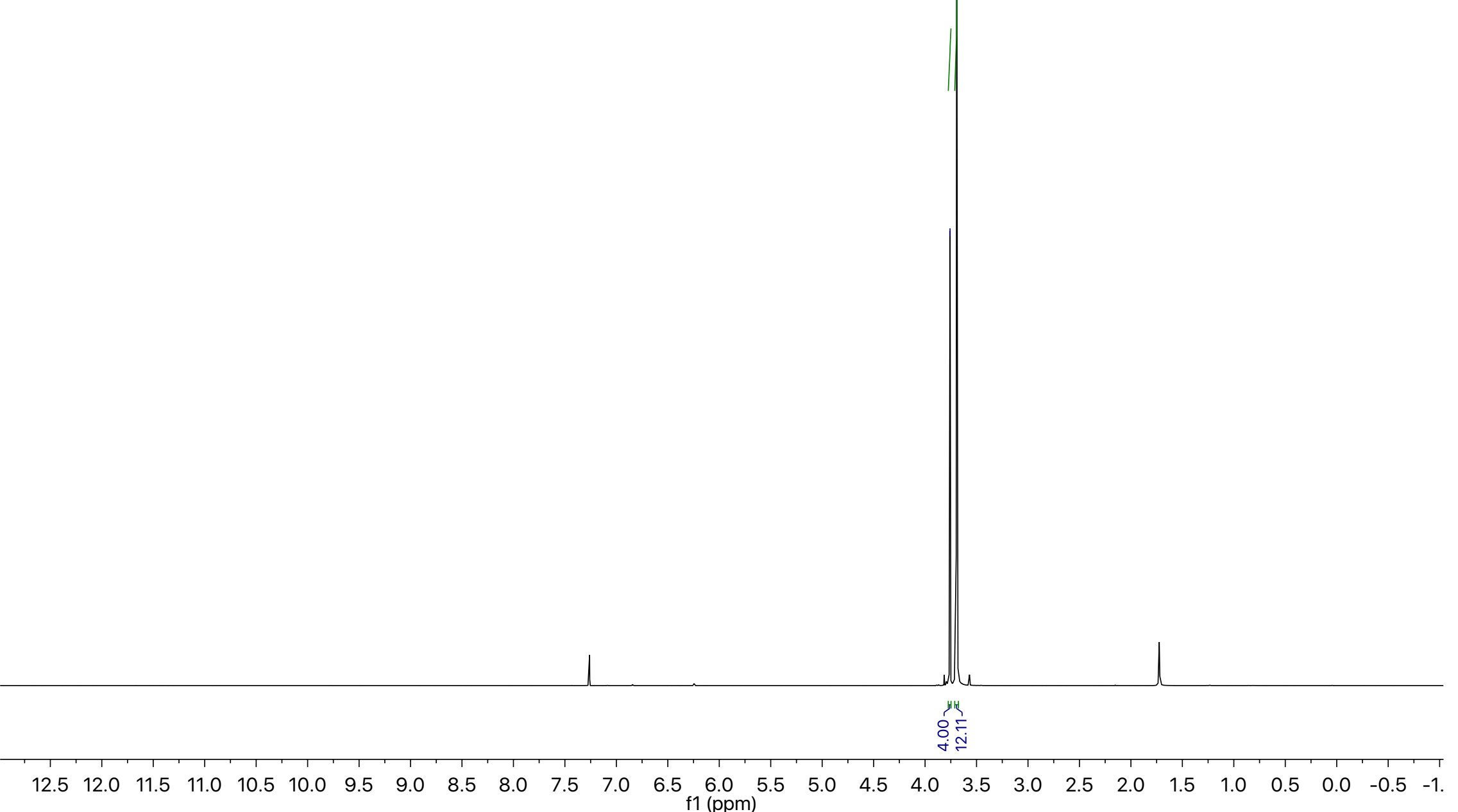


Compound $8{ }^{13} \mathrm{C}$ NMR

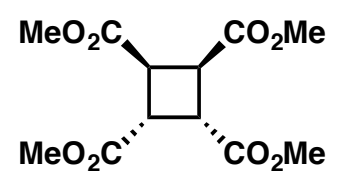

$\stackrel{\stackrel{+}{*}}{\frac{1}{1}}$

1
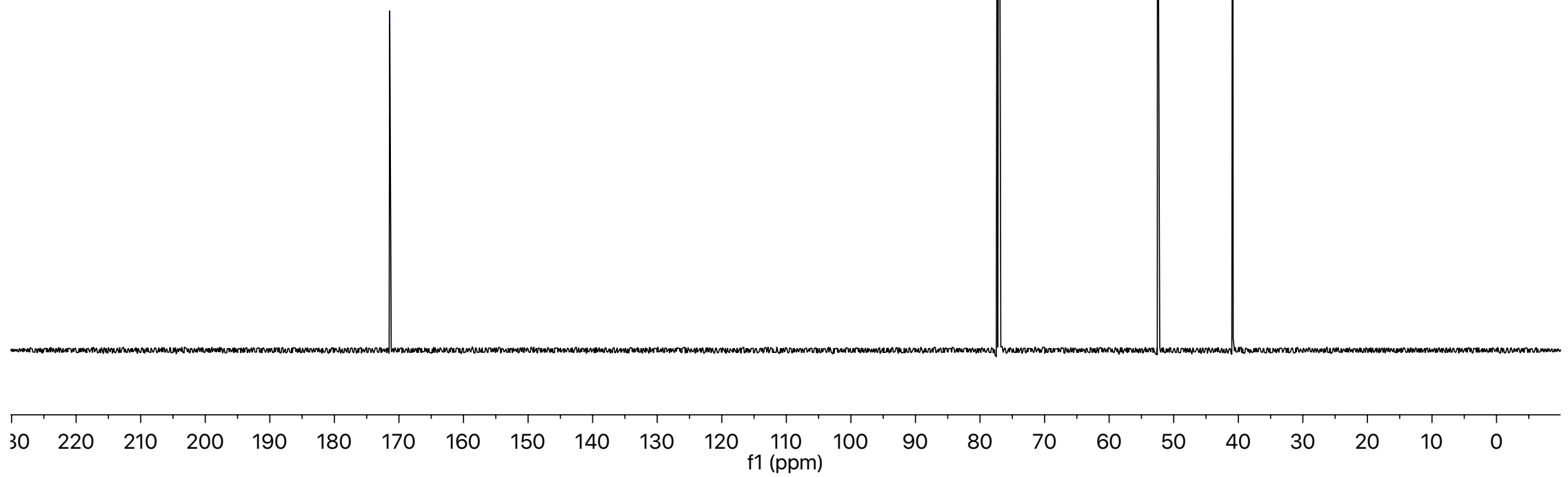

S57 


\section{Compound $2{ }^{1} \mathrm{H}$ NMR}

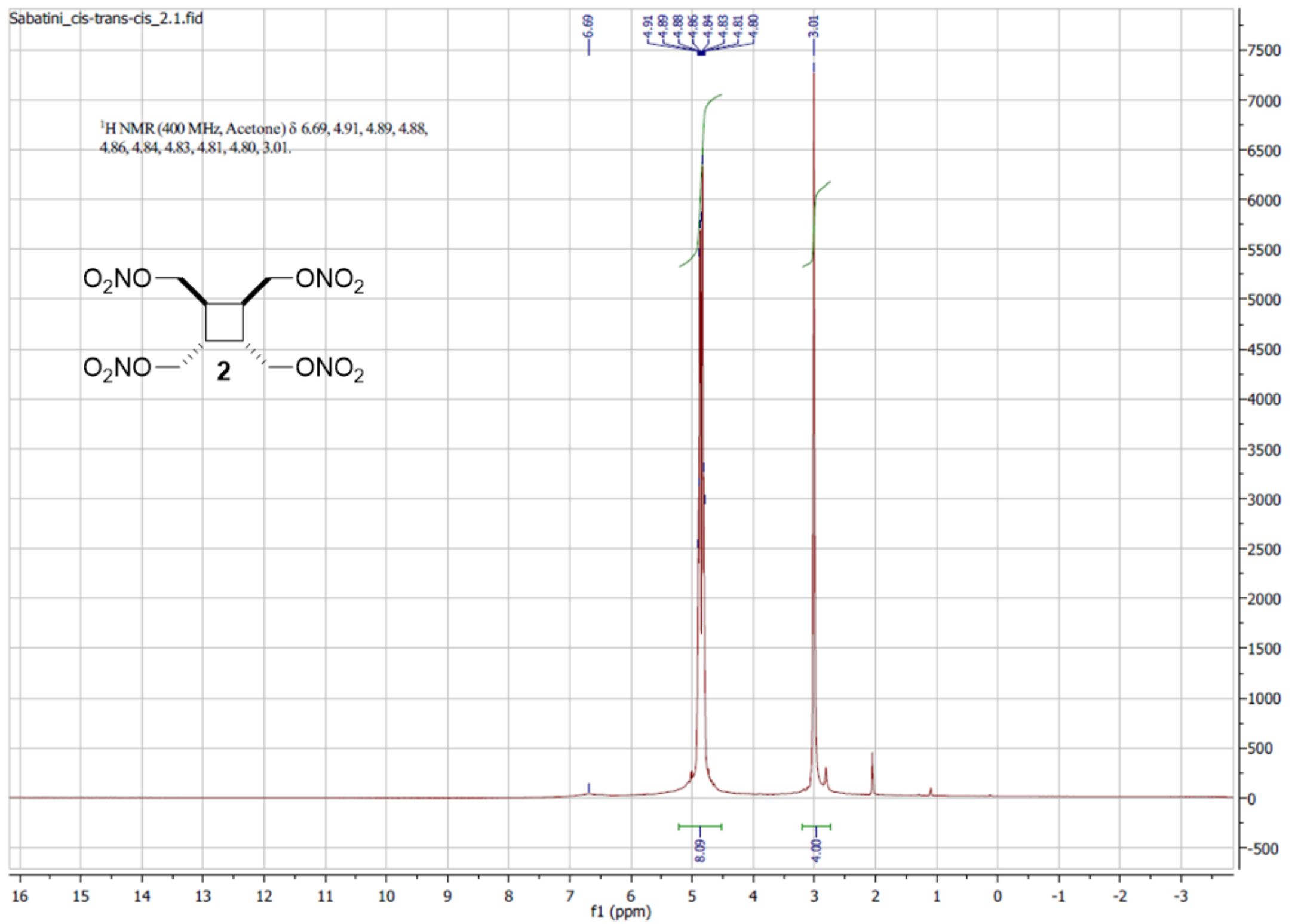




\section{Compound $2{ }^{13} \mathrm{C}$ NMR}

Sabatini_cis-trans-cis_2.2.fid

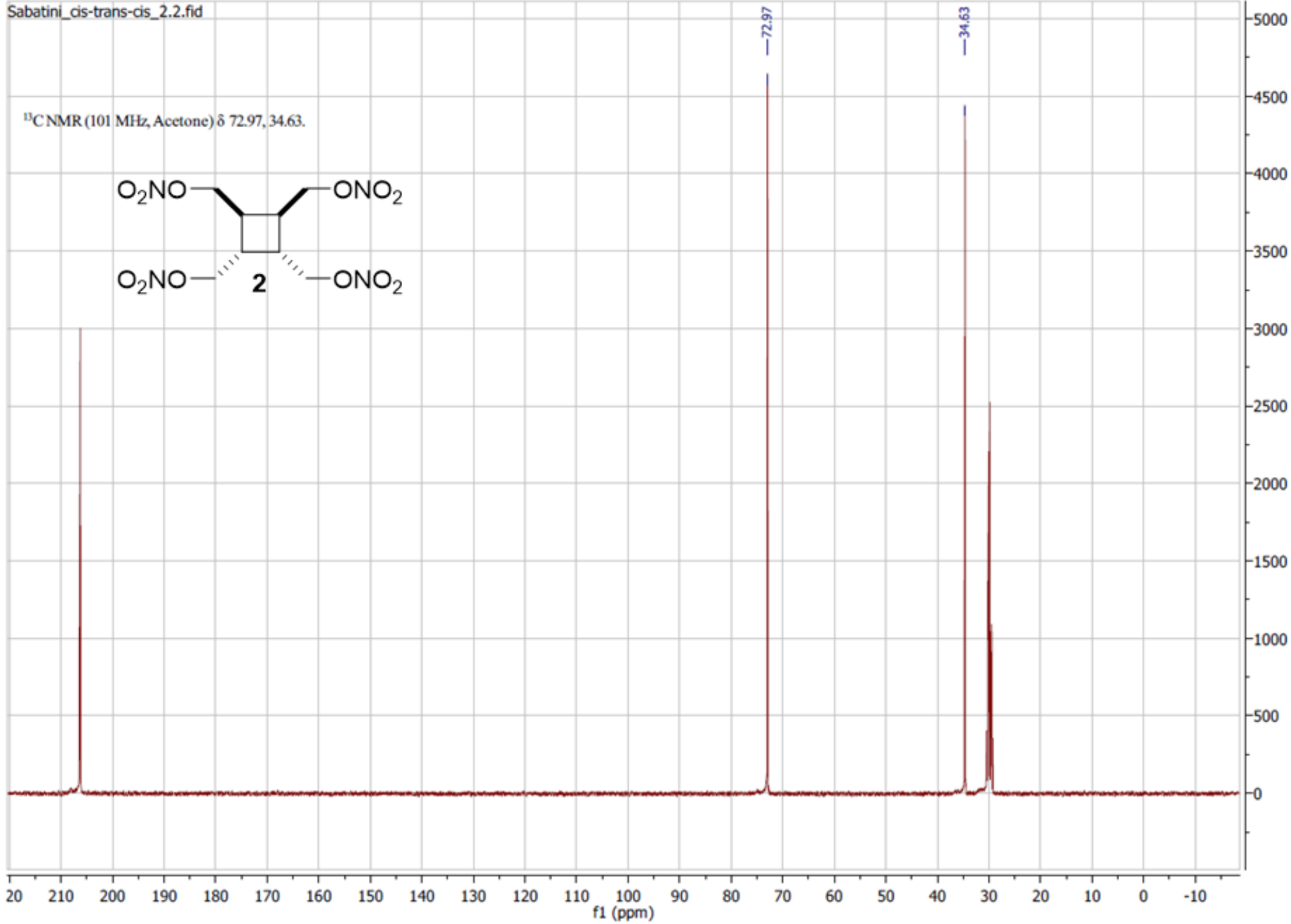




\section{Compound $9{ }^{1} \mathrm{H}$ NMR}

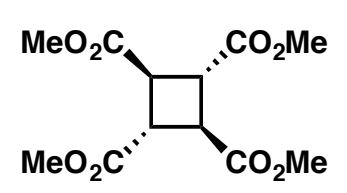

$\mathrm{MeO}_{2} \mathrm{C}^{\prime} \quad \mathrm{CO}_{2} \mathrm{Me}$

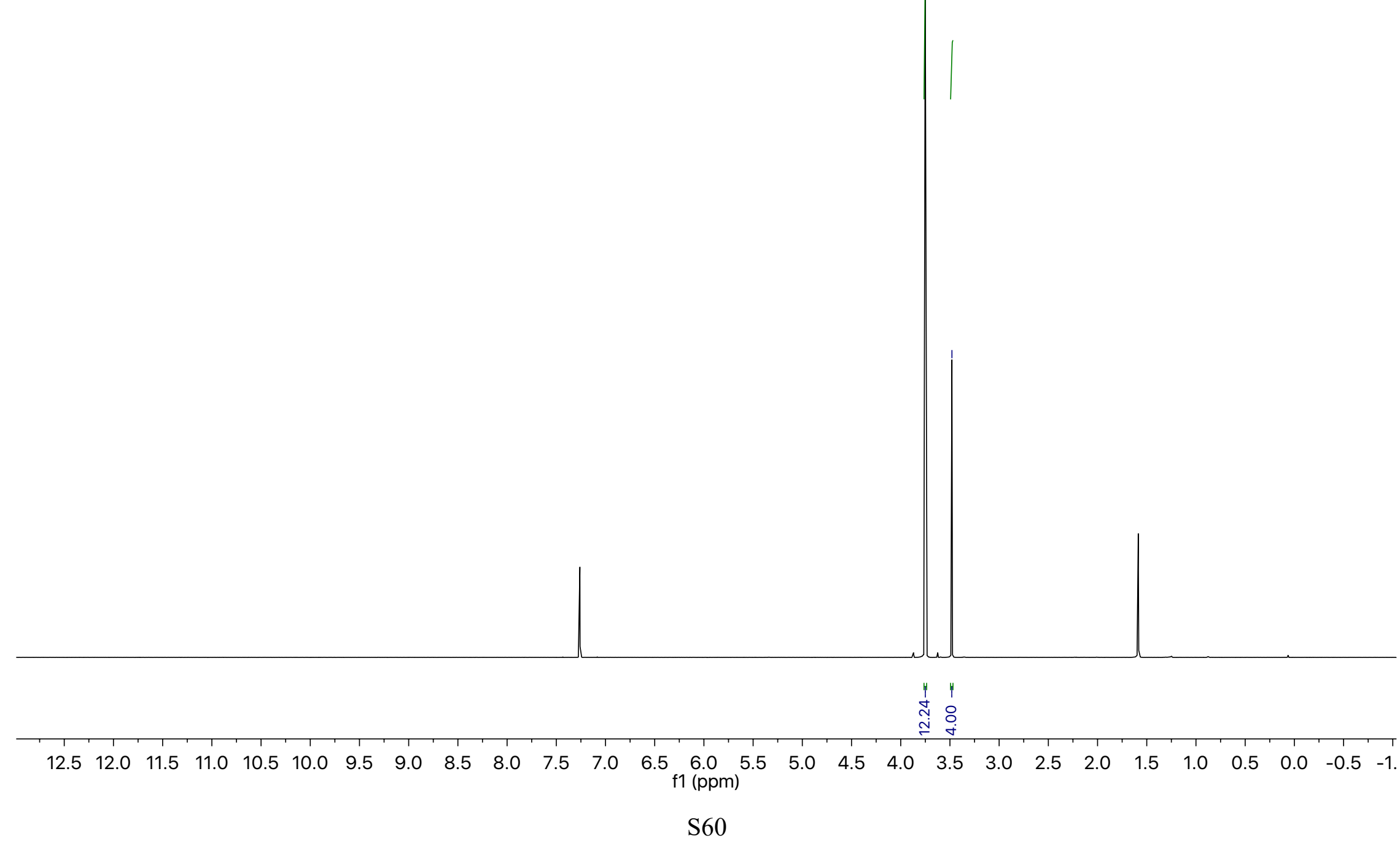




\section{Compound $9{ }^{13} \mathrm{C}$ NMR}

${ }_{\mathrm{MeO}_{2} \mathrm{C}} \mathrm{MeO}_{2} \mathrm{C}{ }_{\mathrm{CO}_{2} \mathrm{Me}}^{. \mathrm{CO}_{2} \mathrm{Me}}$

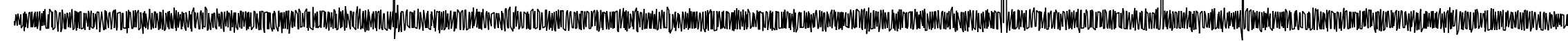

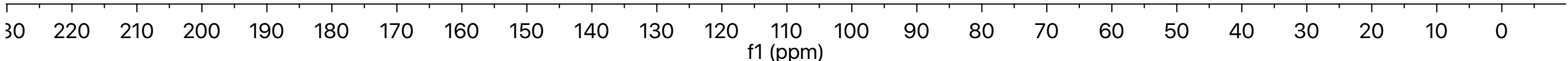




\section{Compound $3{ }^{1} \mathrm{H}$ NMR}

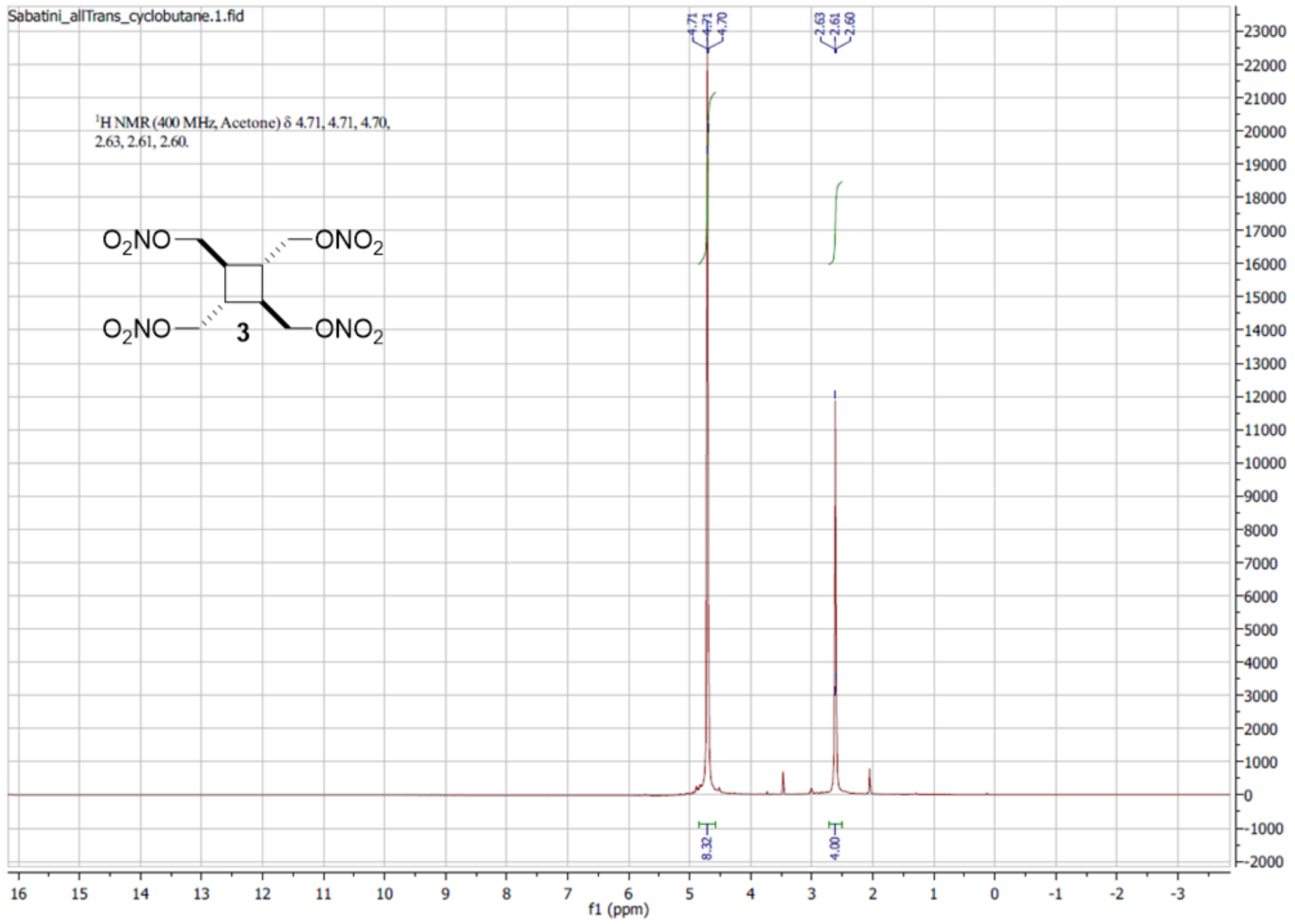




\section{Compound $3{ }^{13} \mathrm{C}$ NMR}

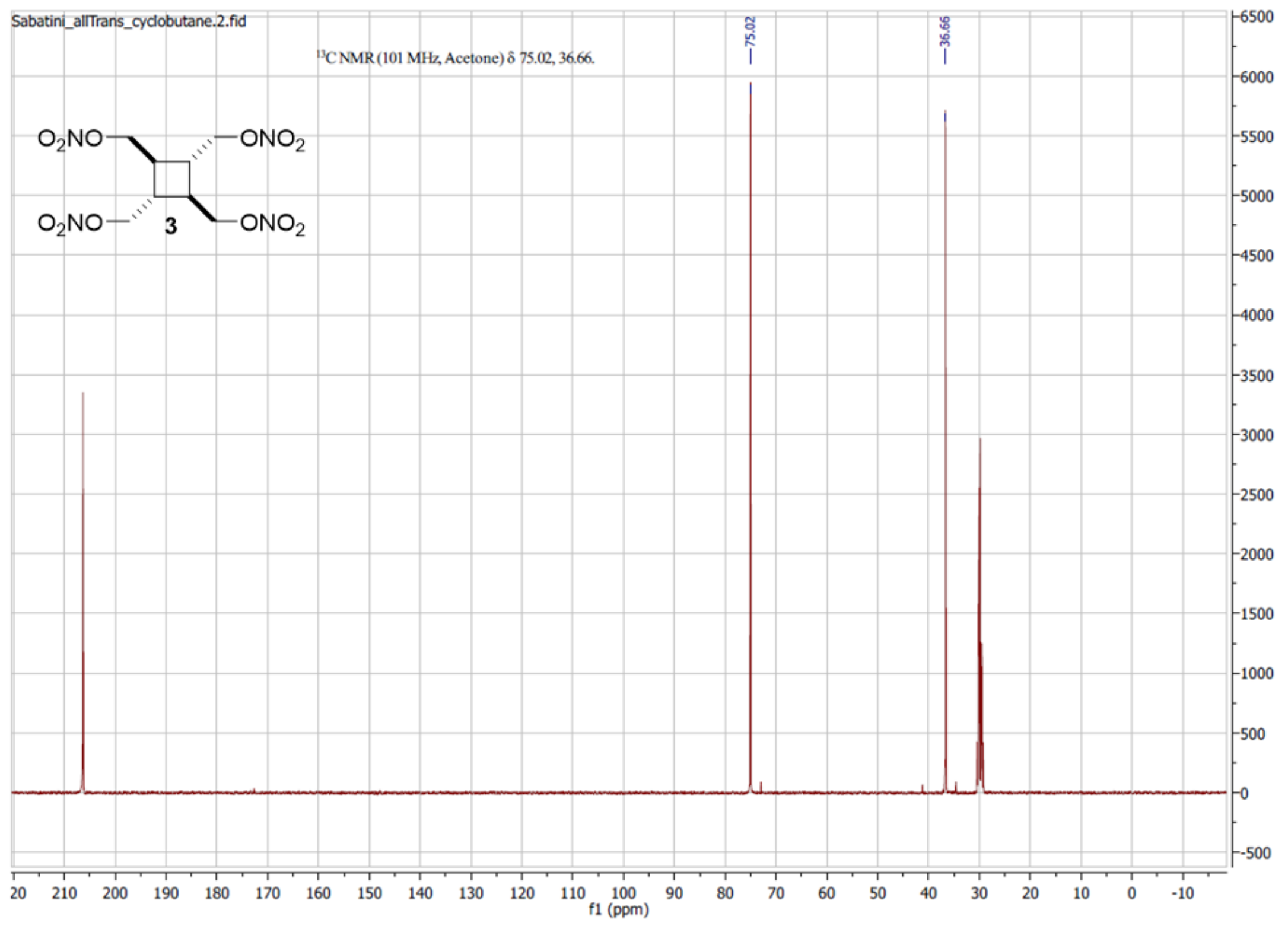




\section{Compound $11{ }^{1} \mathrm{H}$ NMR

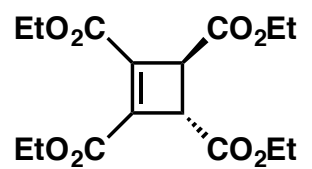 \\ $\mathrm{CO}_{2} \mathrm{Et}$}
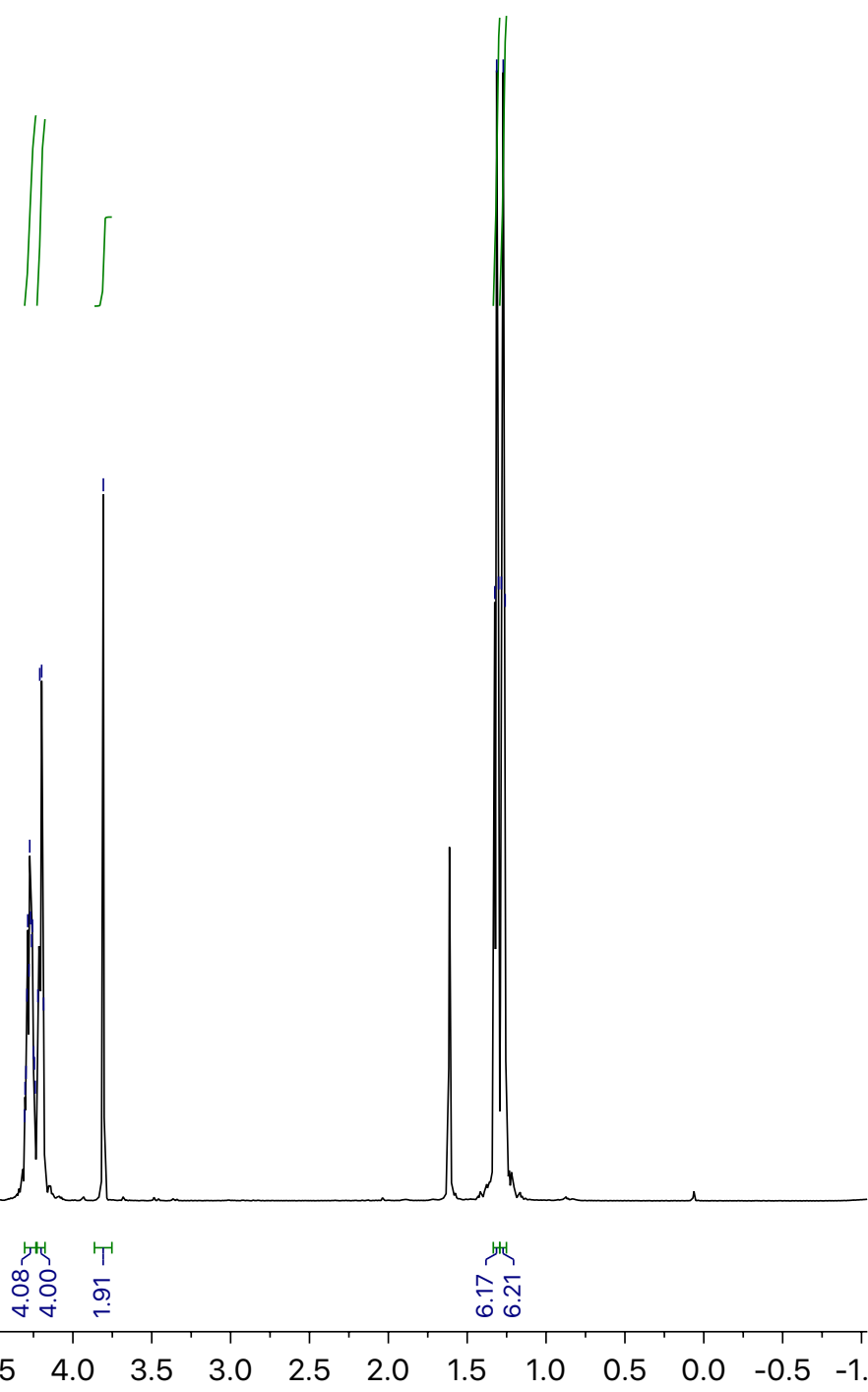

$\begin{array}{llllllllllllll}12.5 & 12.0 & 11.5 & 11.0 & 10.5 & 10.0 & 9.5 & 9.0 & 8.5 & 8.0 & 7.5 & 7.0 & 6.5 & \begin{array}{l}6.0 \\ \mathrm{f} 1(\mathrm{ppm})\end{array}\end{array}$ 
Compound $11{ }^{13} \mathrm{C}$ NMR<smiles>CCOC(=O)C1=C(C(=O)OCC)[C@H](OCC)C1C(=O)OCC</smiles>

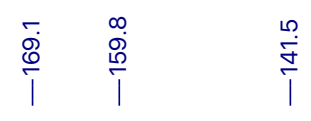

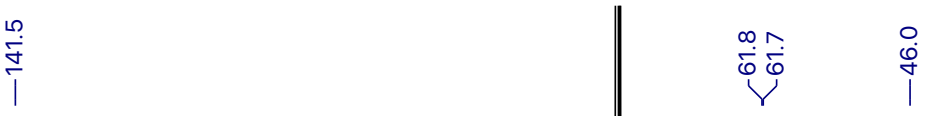

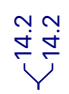
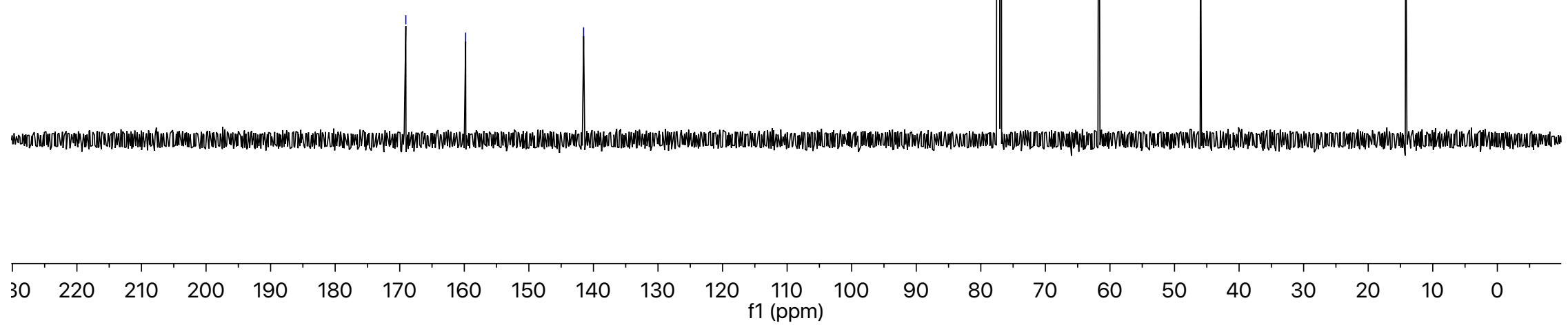

S65 


\section{Compound $12{ }^{1} \mathrm{H}$ NMR}

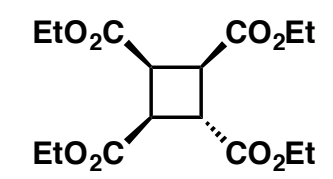

$\mathrm{EtO}_{2} \mathrm{C} \quad \mathrm{CO}_{2} \mathrm{Et}$

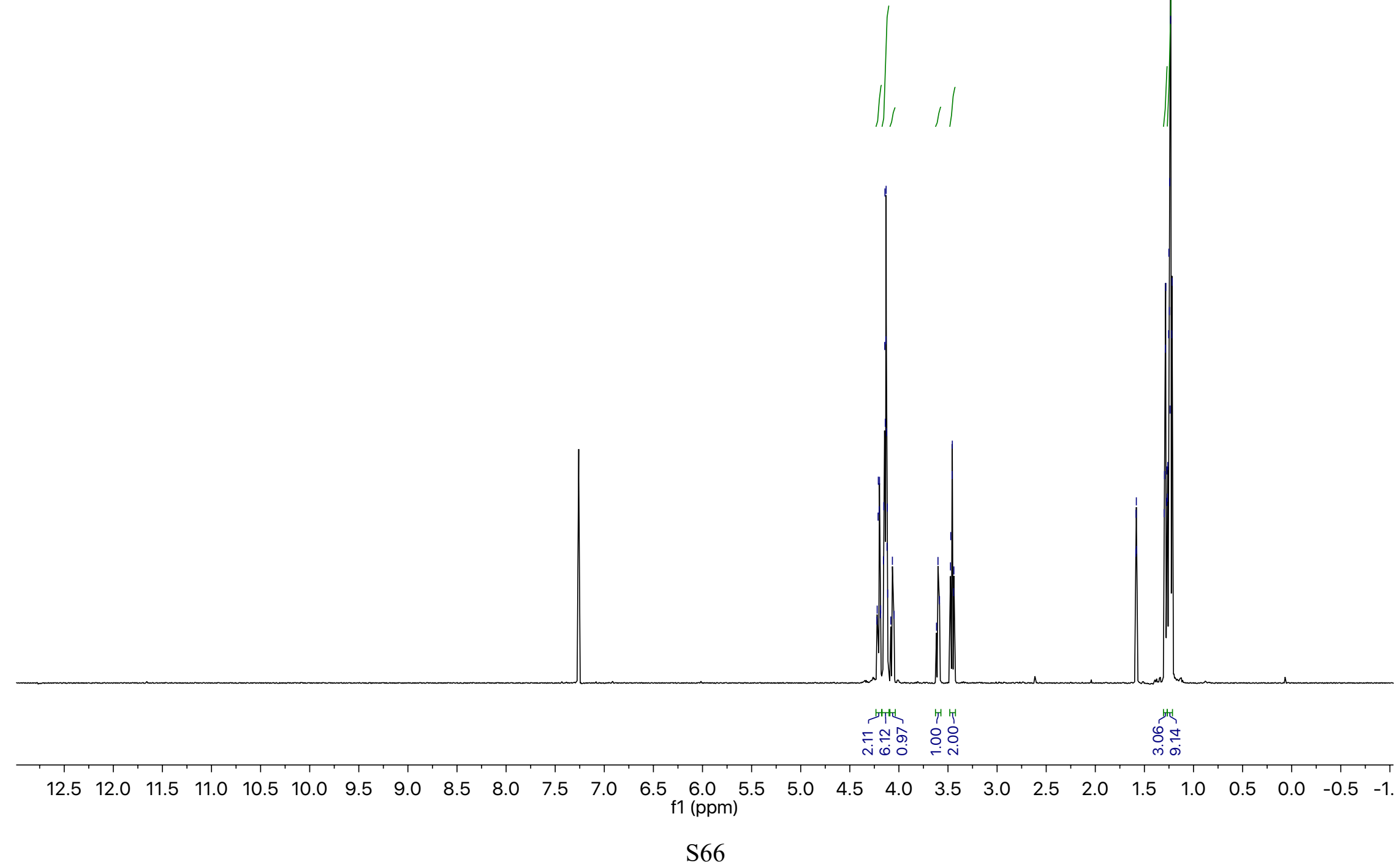



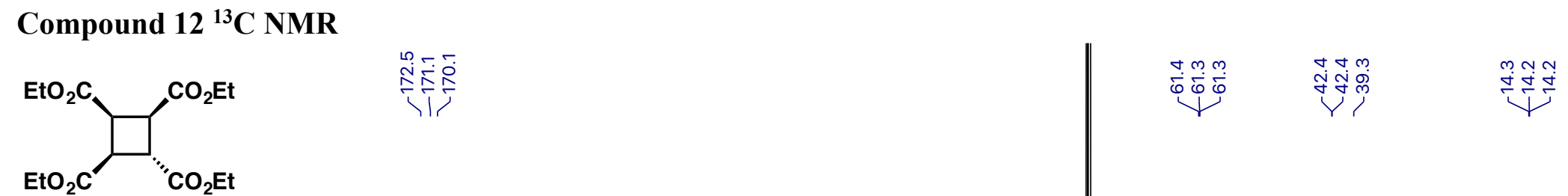

$\mathrm{EtO}_{2} \mathrm{C} \quad \mathrm{CO}_{2} \mathrm{Et}$

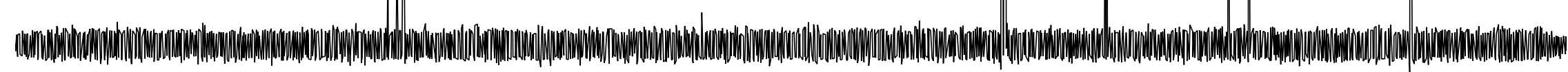

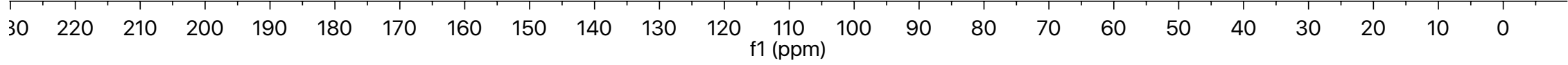




\section{Compound $4{ }^{1} \mathrm{H}$ NMR}

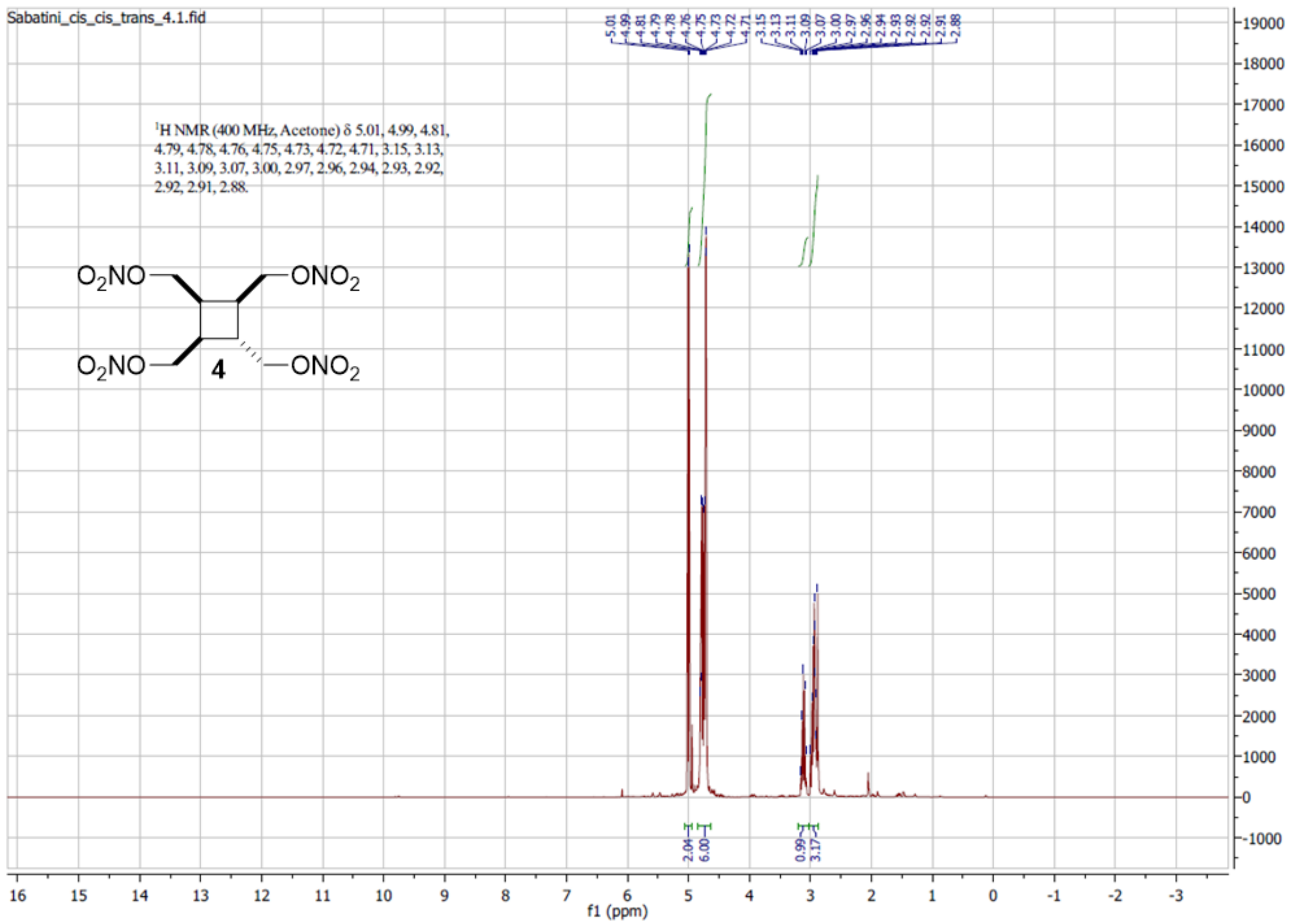




\section{Compound $4{ }^{13} \mathrm{C}$ NMR}

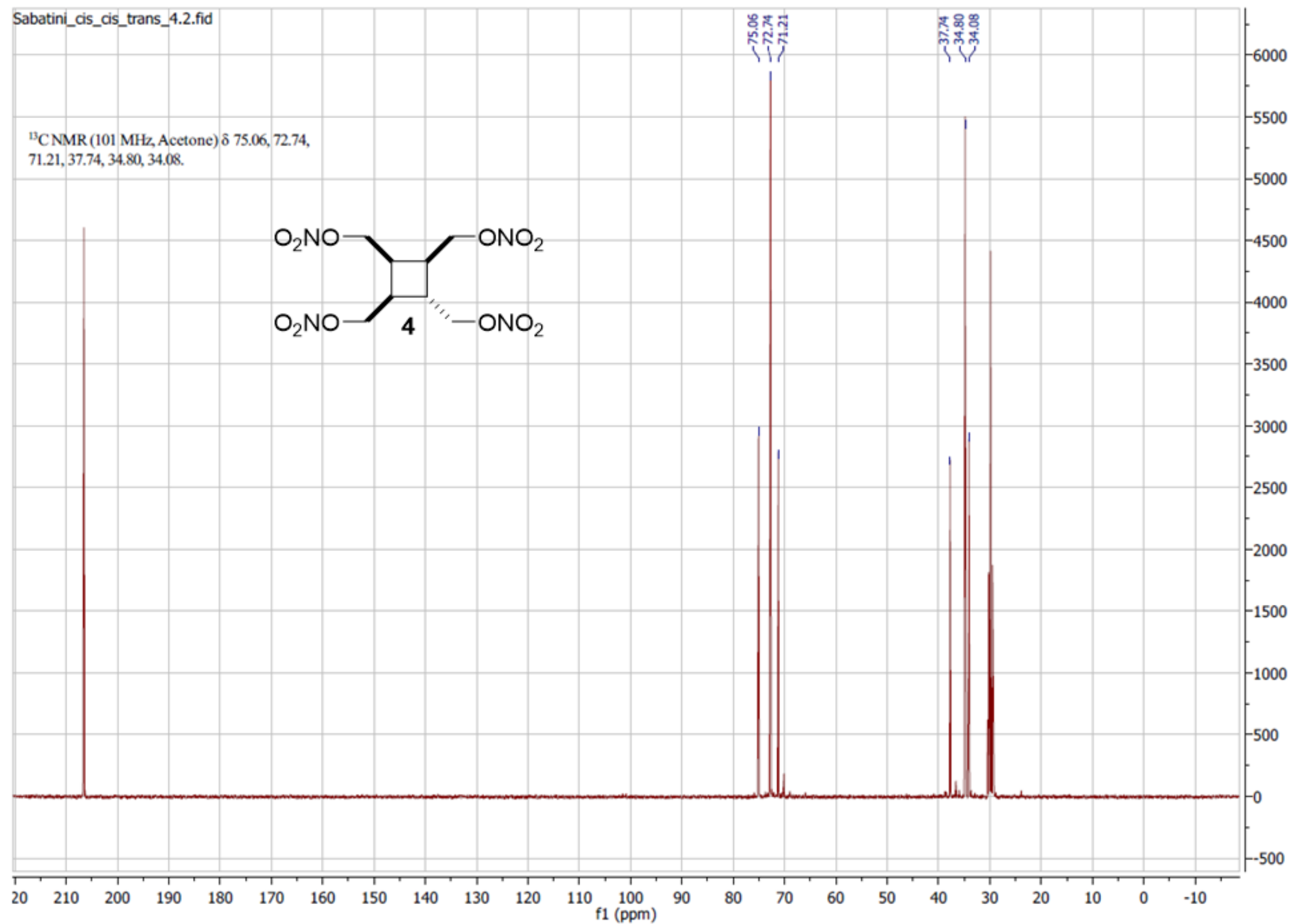




\section{Compound SI-2 ${ }^{1} \mathrm{H}$ NMR}

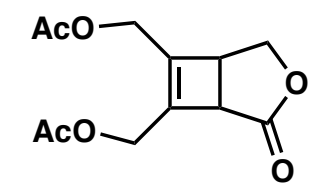

0

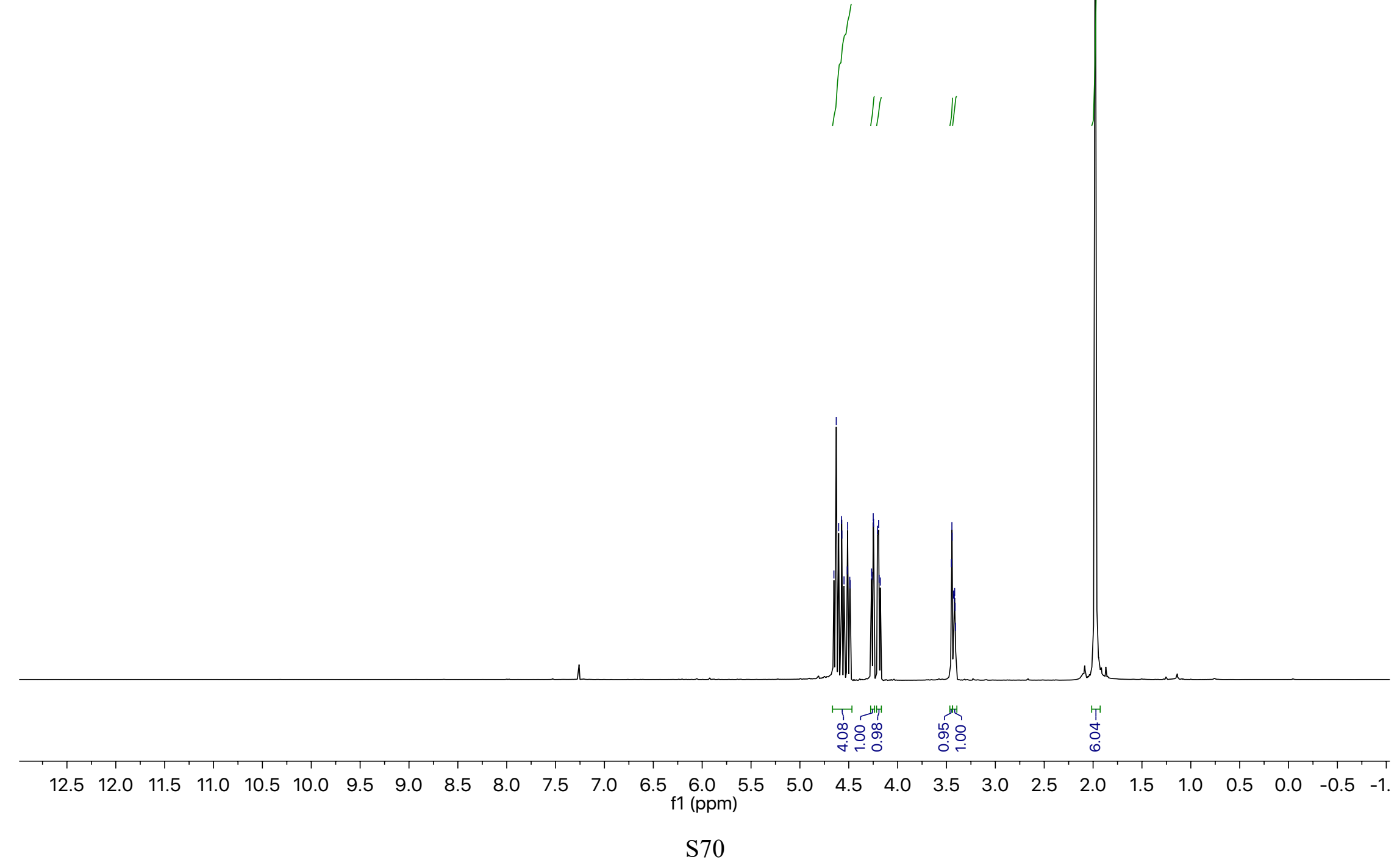




\section{Compound SI-2 ${ }^{13} \mathrm{C}$ NMR}

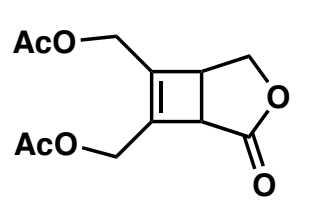

0

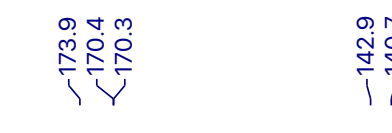

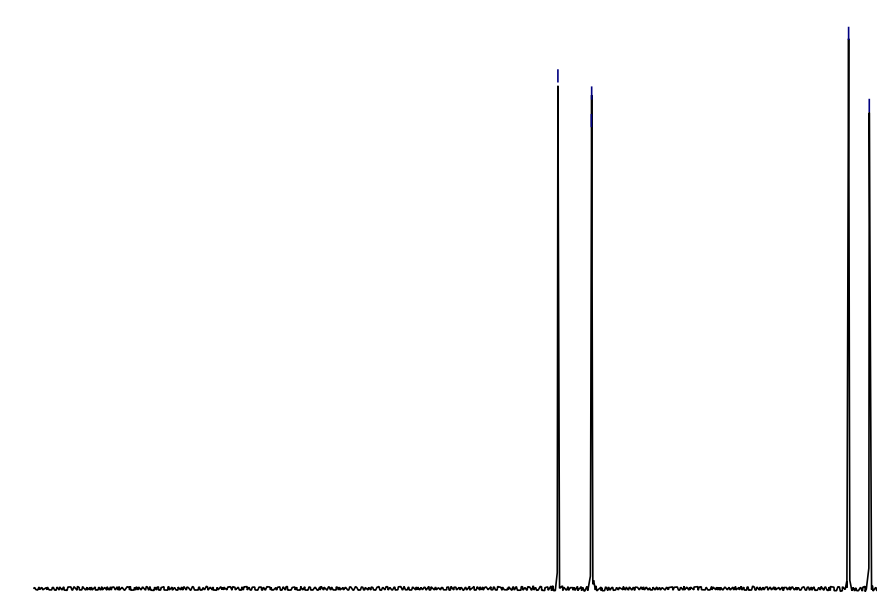




\section{Compound $13{ }^{1}$ H NMR}

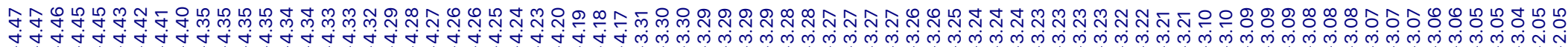<smiles>CC(=O)OCC1C(COC(C)=O)C2C(=O)OCC12</smiles>

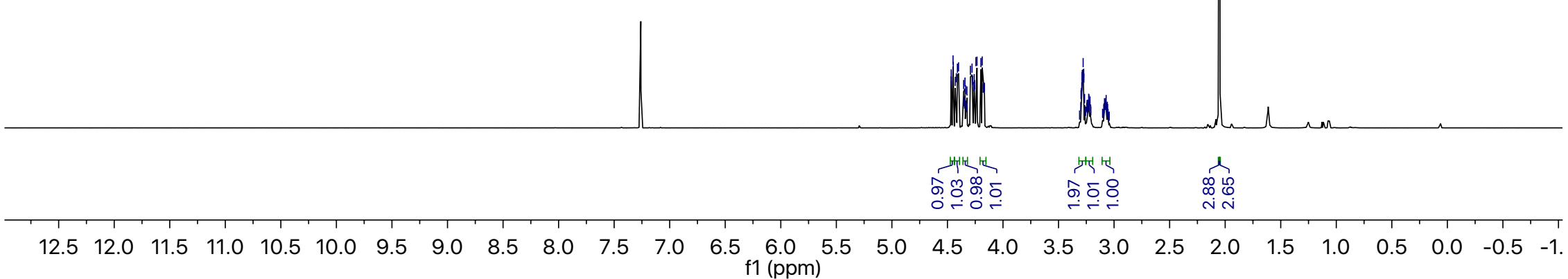




\section{Compound $13{ }^{13} \mathrm{C}$ NMR}

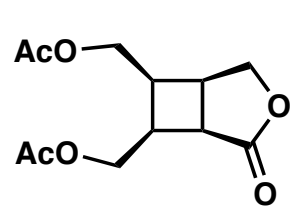

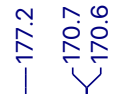

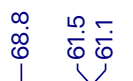

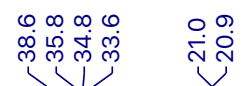

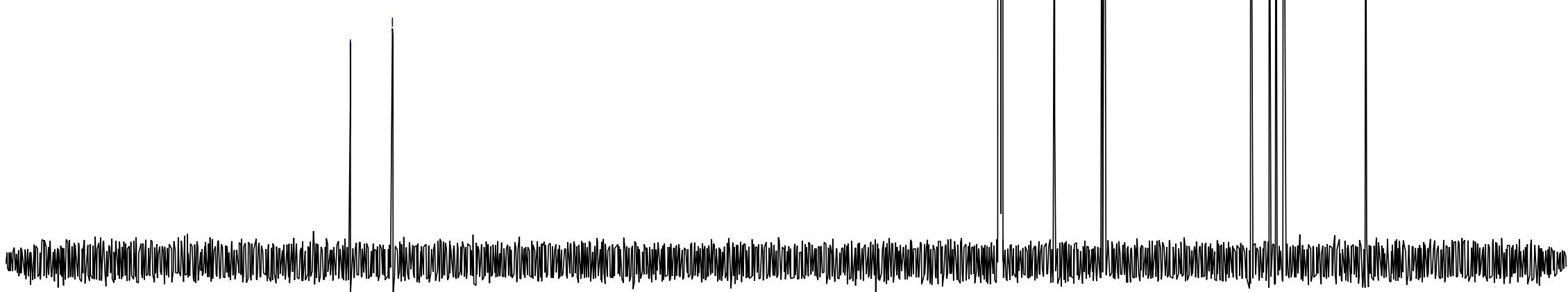

$30 \quad 220$

$200 \quad 190$

180

$170 \quad 160$

150

140

130

110
f1 $(p p m)$

90

80

60

50

30

20 


\section{Compound $5{ }^{1} \mathrm{H}$ NMR}

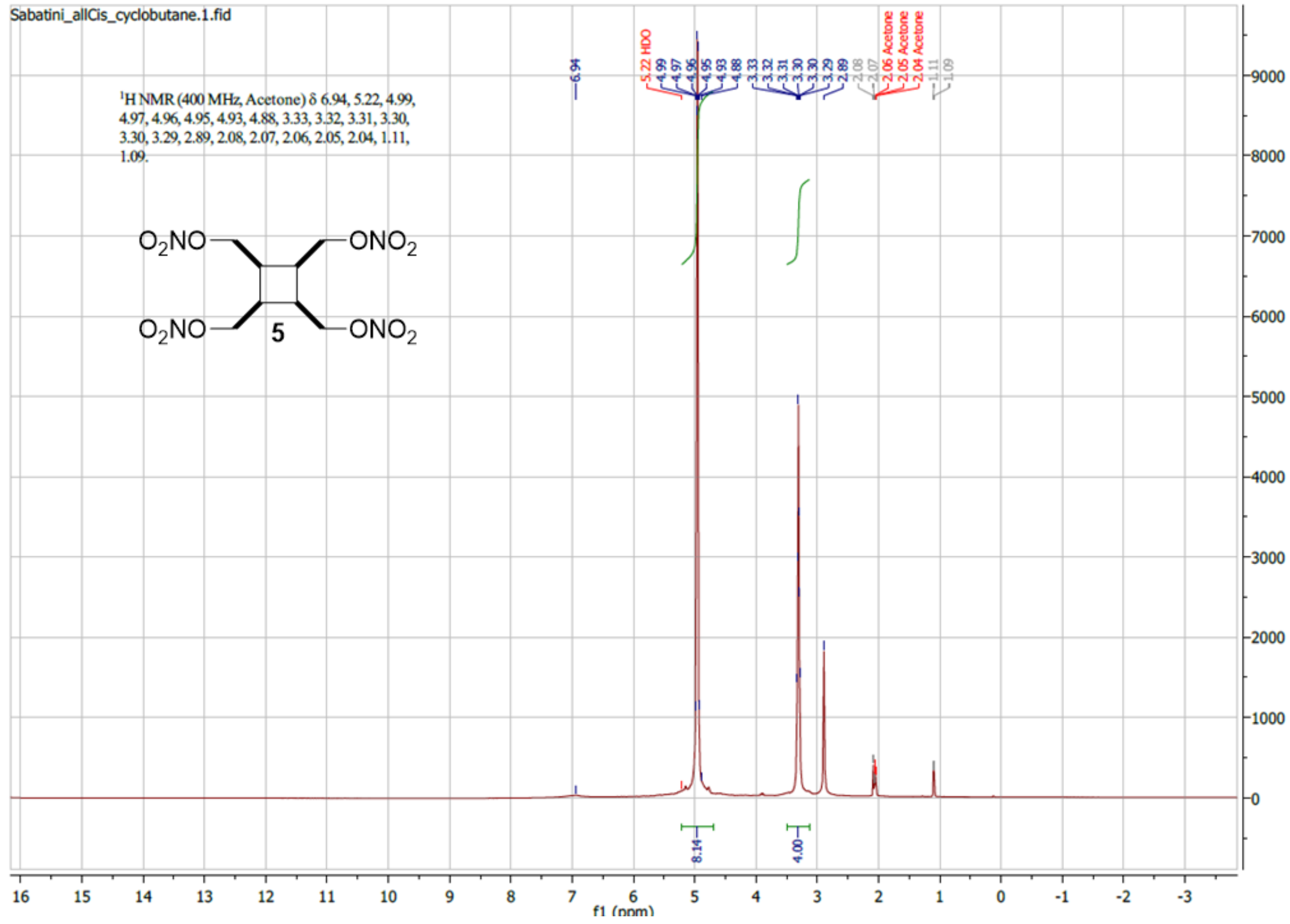




\section{Compound $5{ }^{13} \mathrm{C}$ NMR}

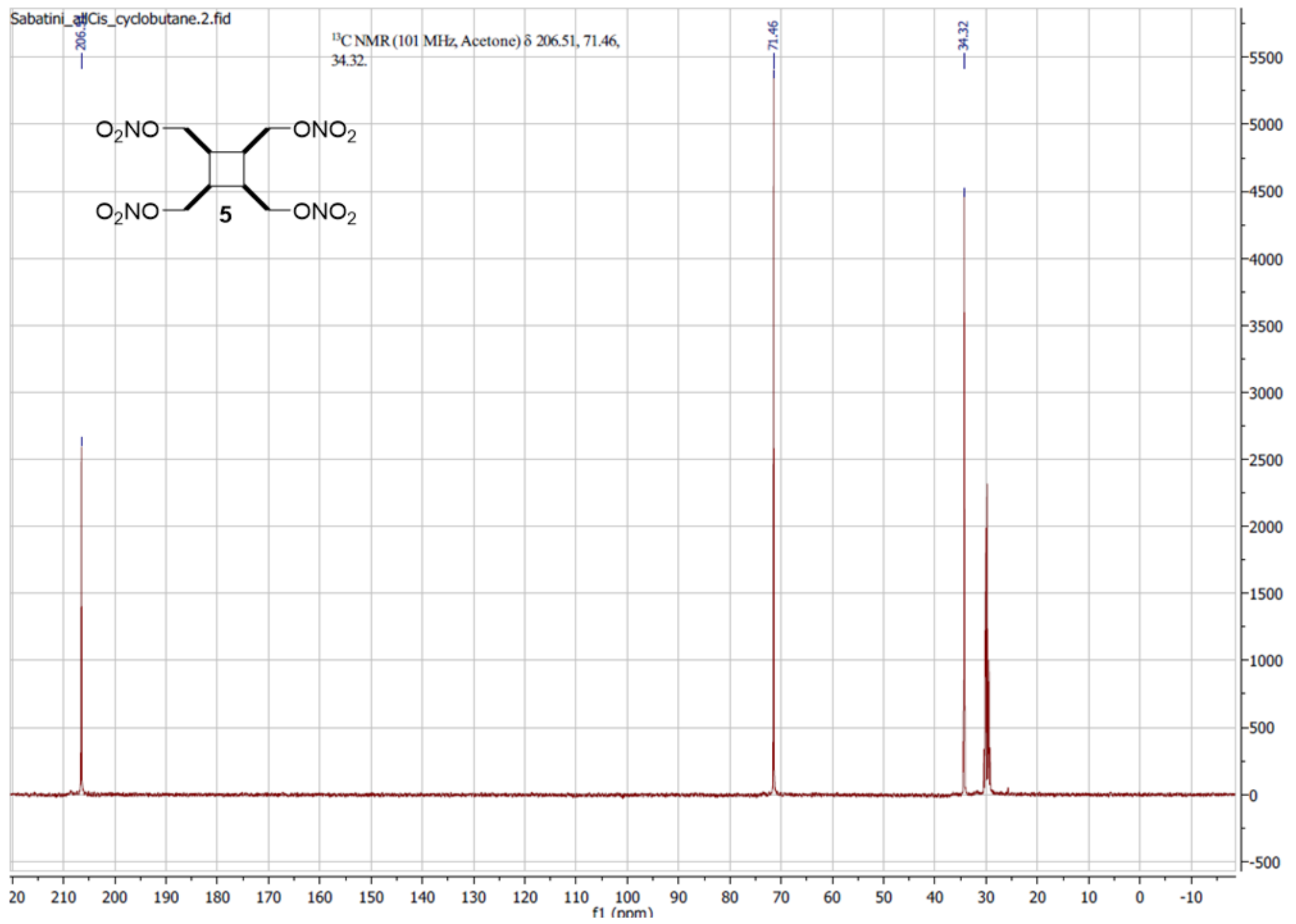




\section{Compound $14{ }^{1} \mathrm{H}$ NMR \\ $\mathrm{MeO}_{2} \mathrm{C} \underbrace{\mathrm{CO}_{2} \mathrm{Me}}_{\mathrm{CO}_{2} \mathrm{Me}}$}

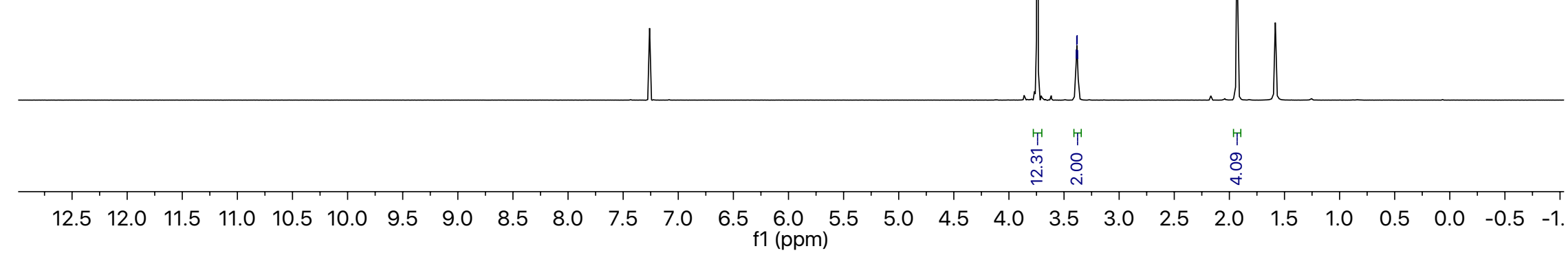




\section{Compound $14{ }^{13} \mathrm{C}$ NMR}

$\mathrm{MeO}_{2} \underbrace{\mathrm{CO}_{2} \mathrm{Me}}_{\mathrm{CO}_{2} \mathrm{Me}}$

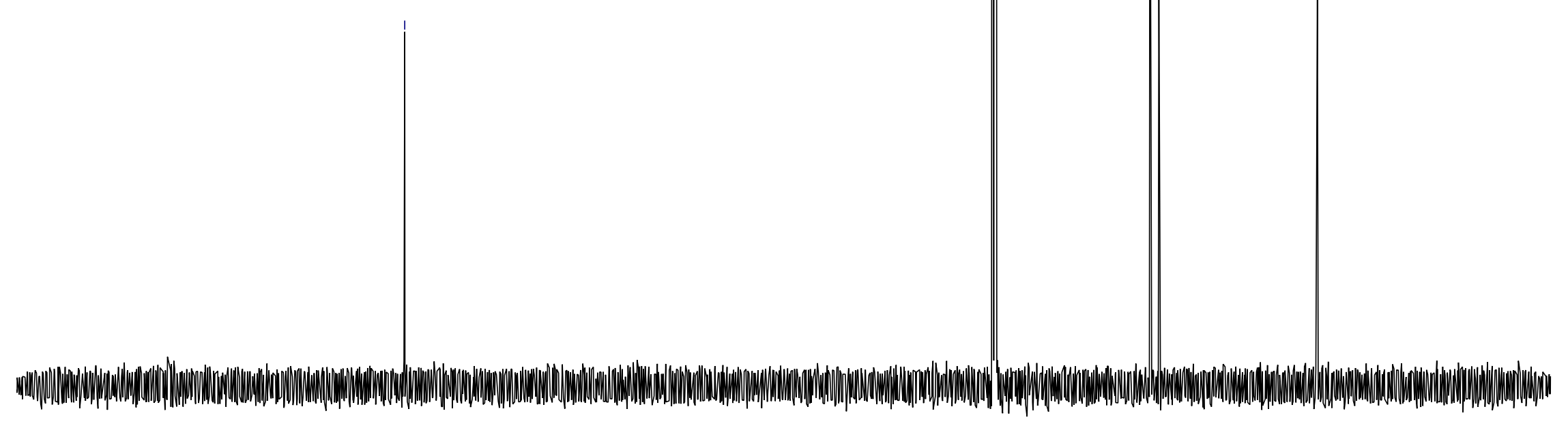

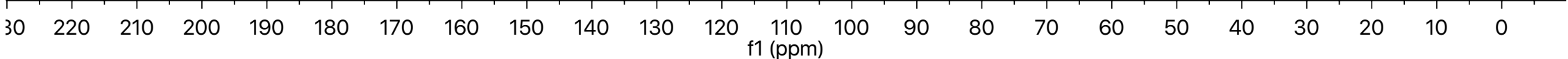




\section{Compound $15{ }^{1} \mathrm{H}$ NMR}

$\mathrm{MeO}_{2} \mathrm{C} \quad \mathrm{CO}_{2} \mathrm{Me}$ $\mathrm{MeO}_{2} \mathrm{C} \longrightarrow \mathrm{CO}_{2} \mathrm{Me}$

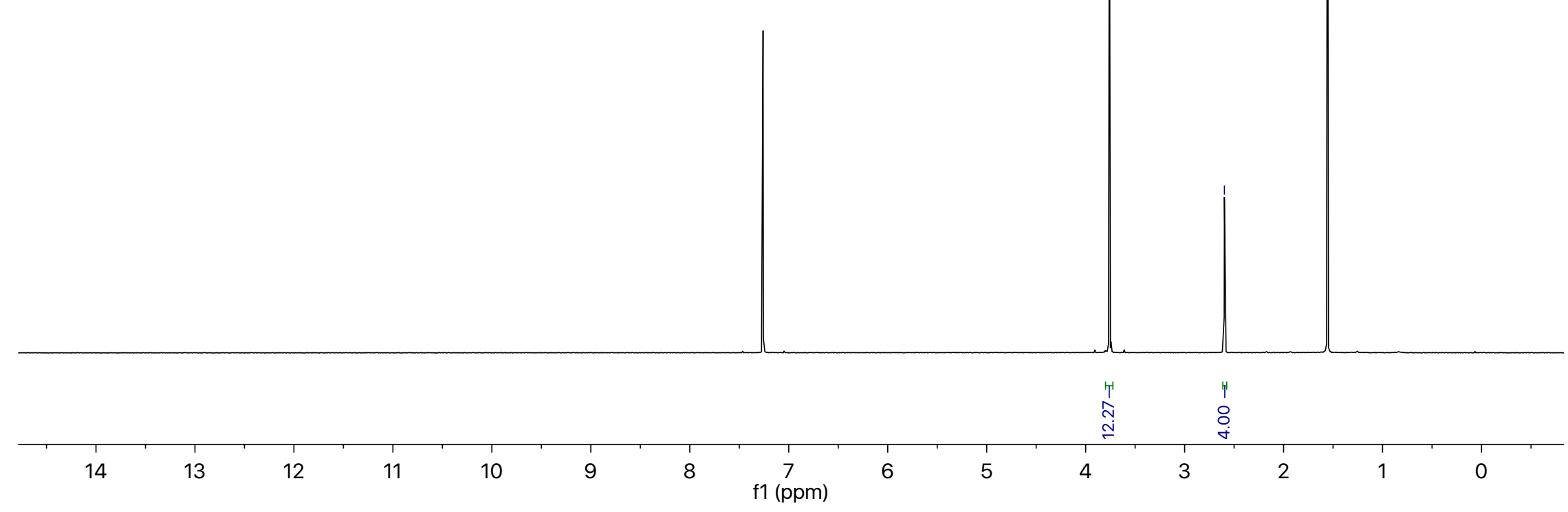




\section{Compound $15{ }^{13} \mathrm{C}$ NMR}

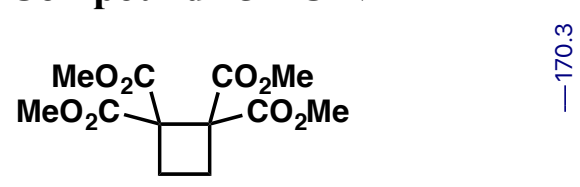

1

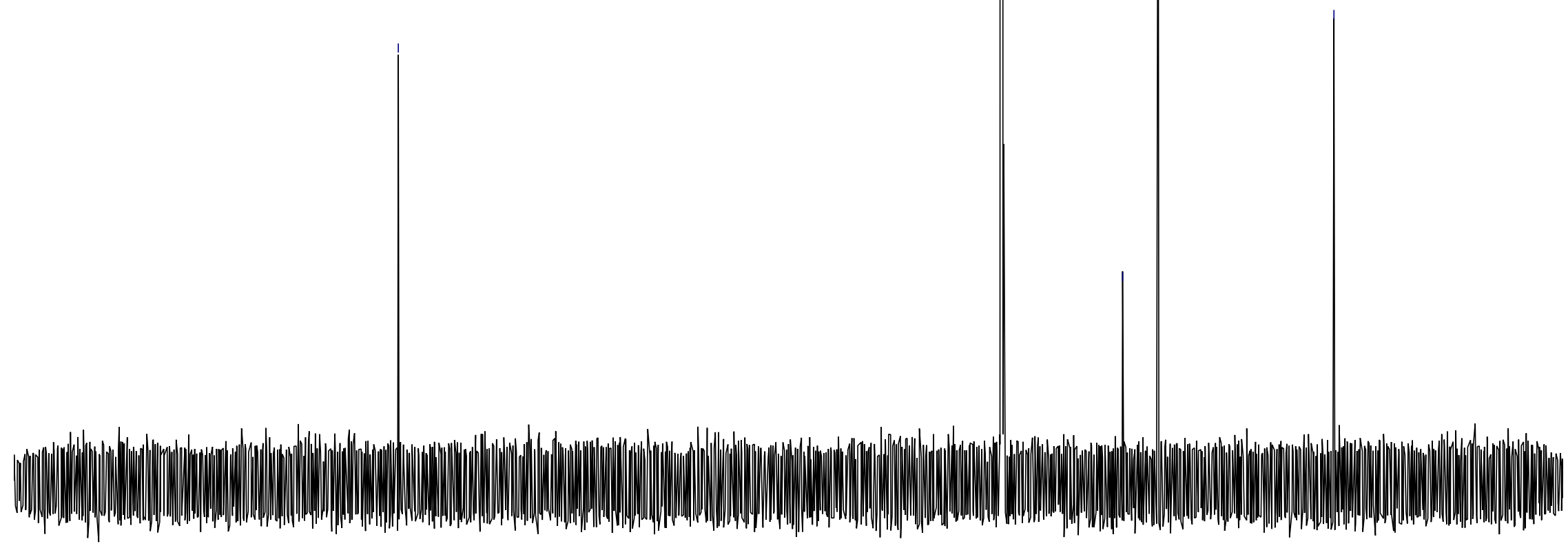




\section{Compound $6{ }^{1} \mathrm{H}$ NMR}

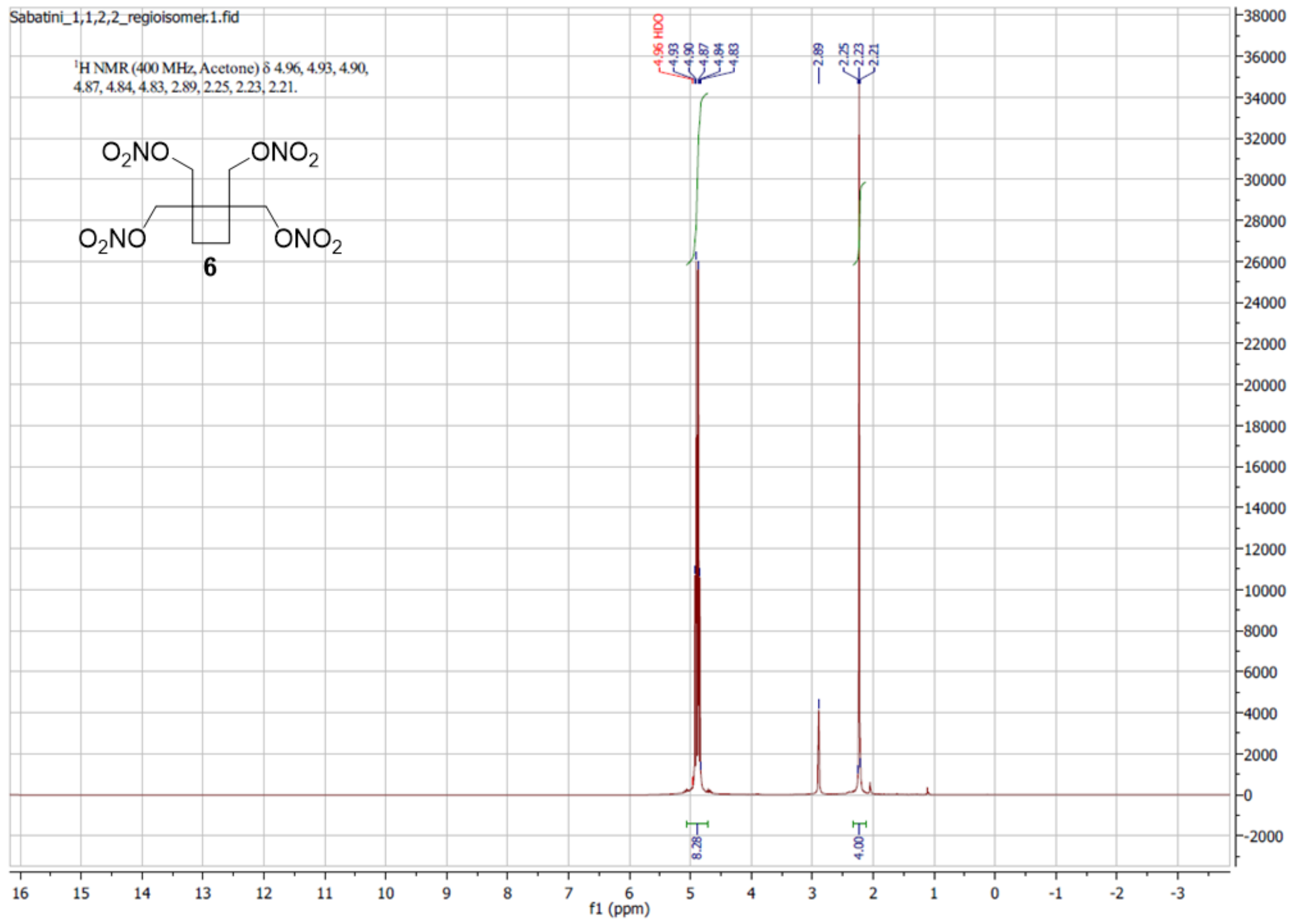




\section{Compound $6{ }^{13} \mathrm{C}$ NMR}

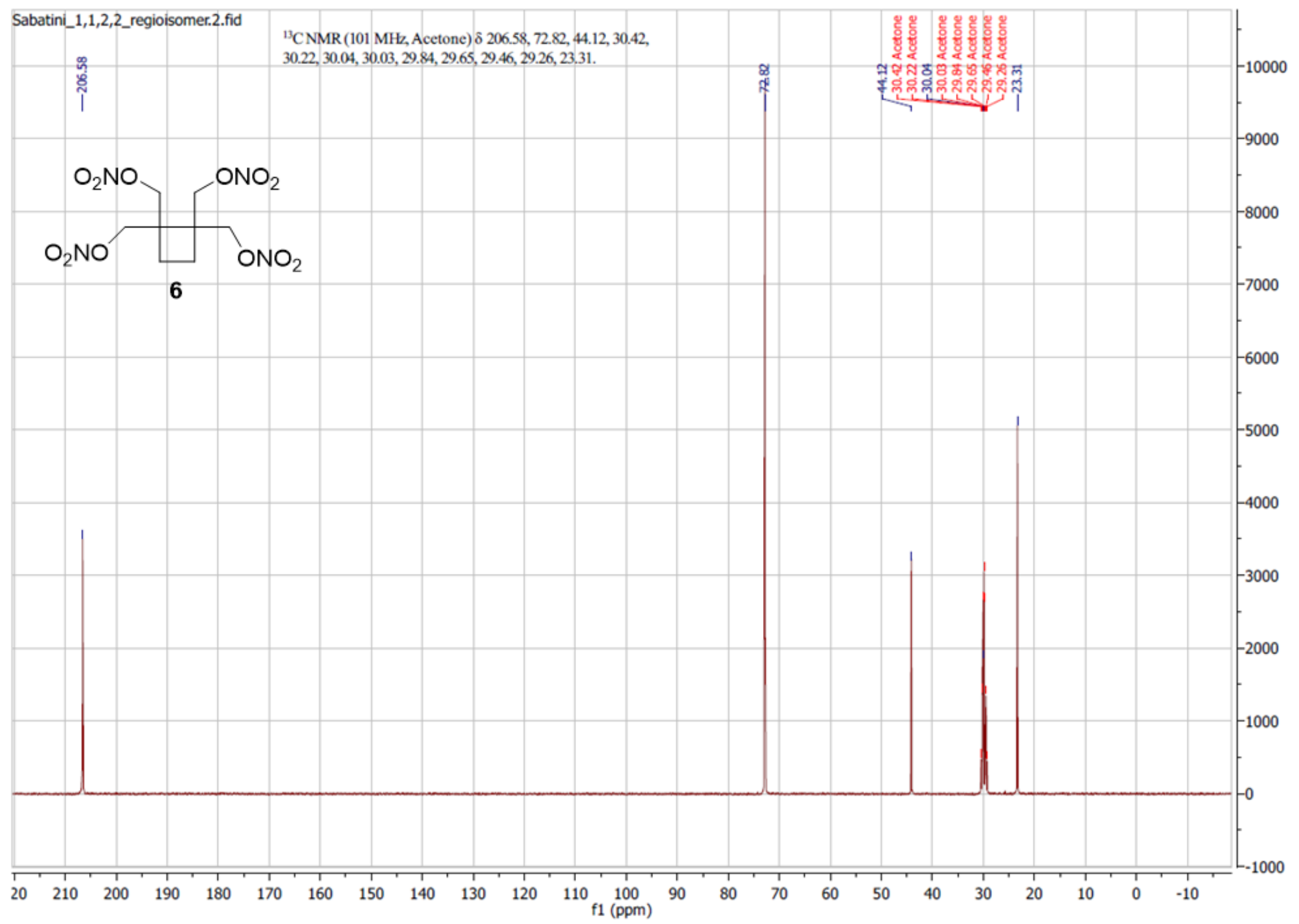




\section{Compound $17{ }^{1} \mathrm{H}$ NMR}
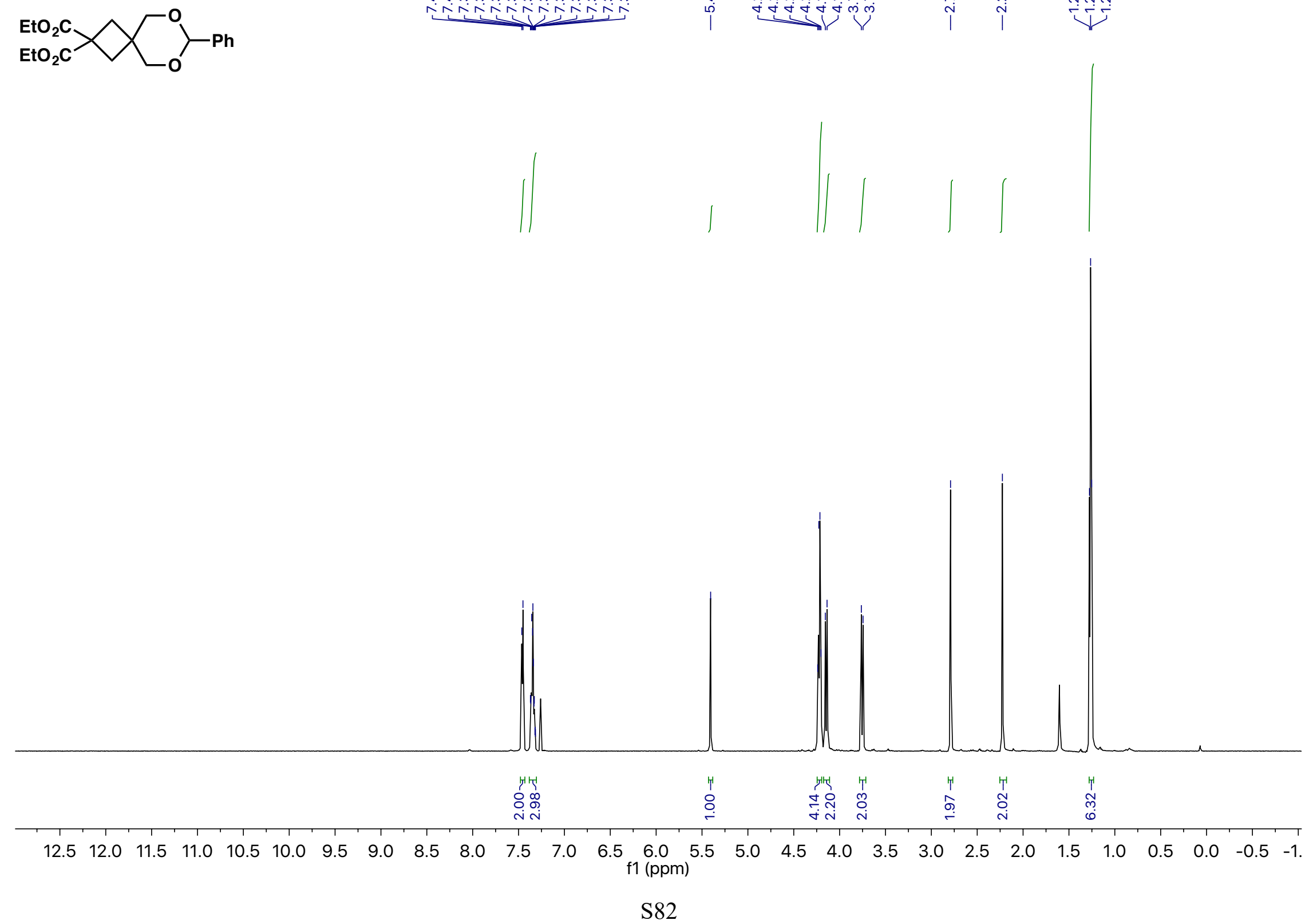
Compound $17{ }^{13} \mathrm{C}$ NMR
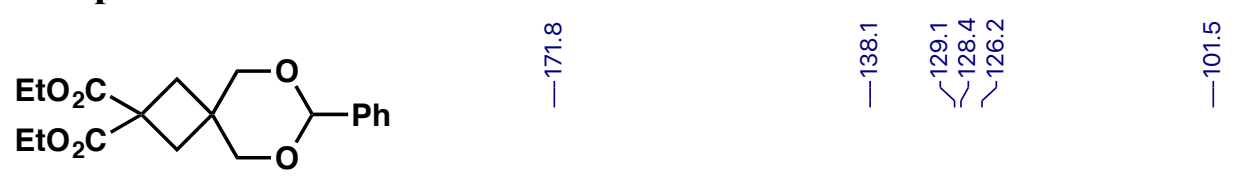

$\stackrel{?}{\grave{0}}$

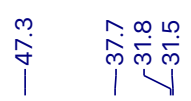

$\stackrel{\text { i }}{\stackrel{1}{*}}$
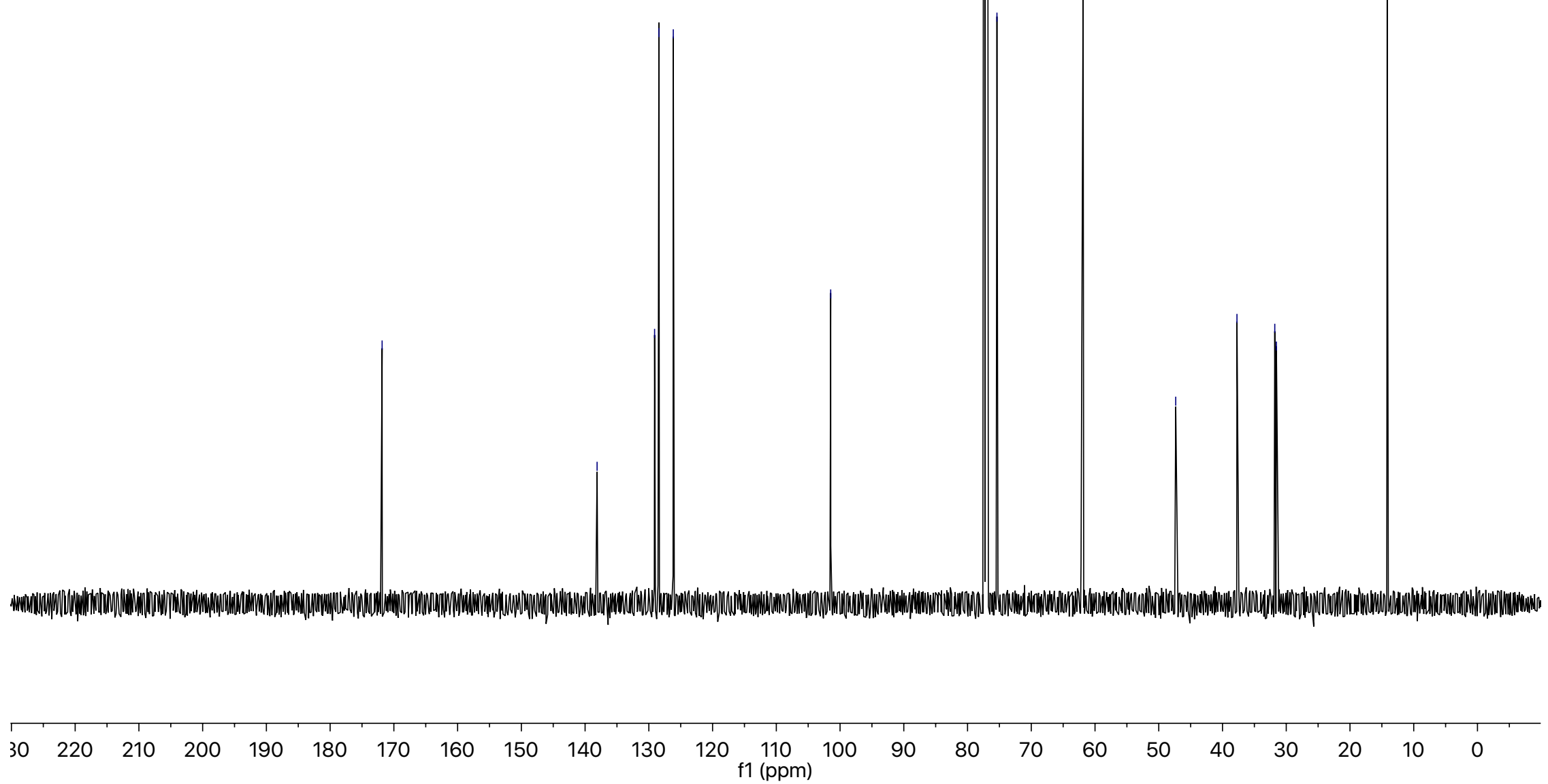

S83 


\section{Compound $18{ }^{1}$ H NMR}
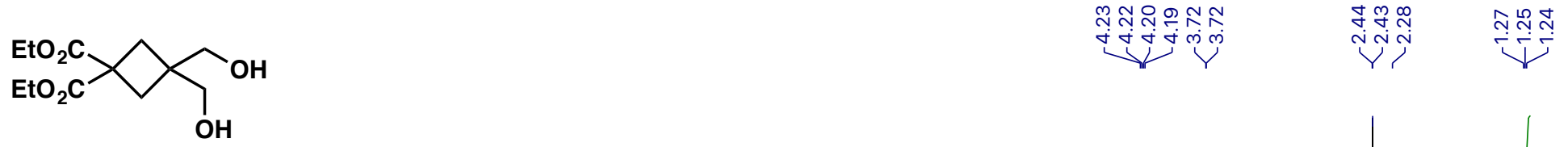

$\mathrm{OH}$

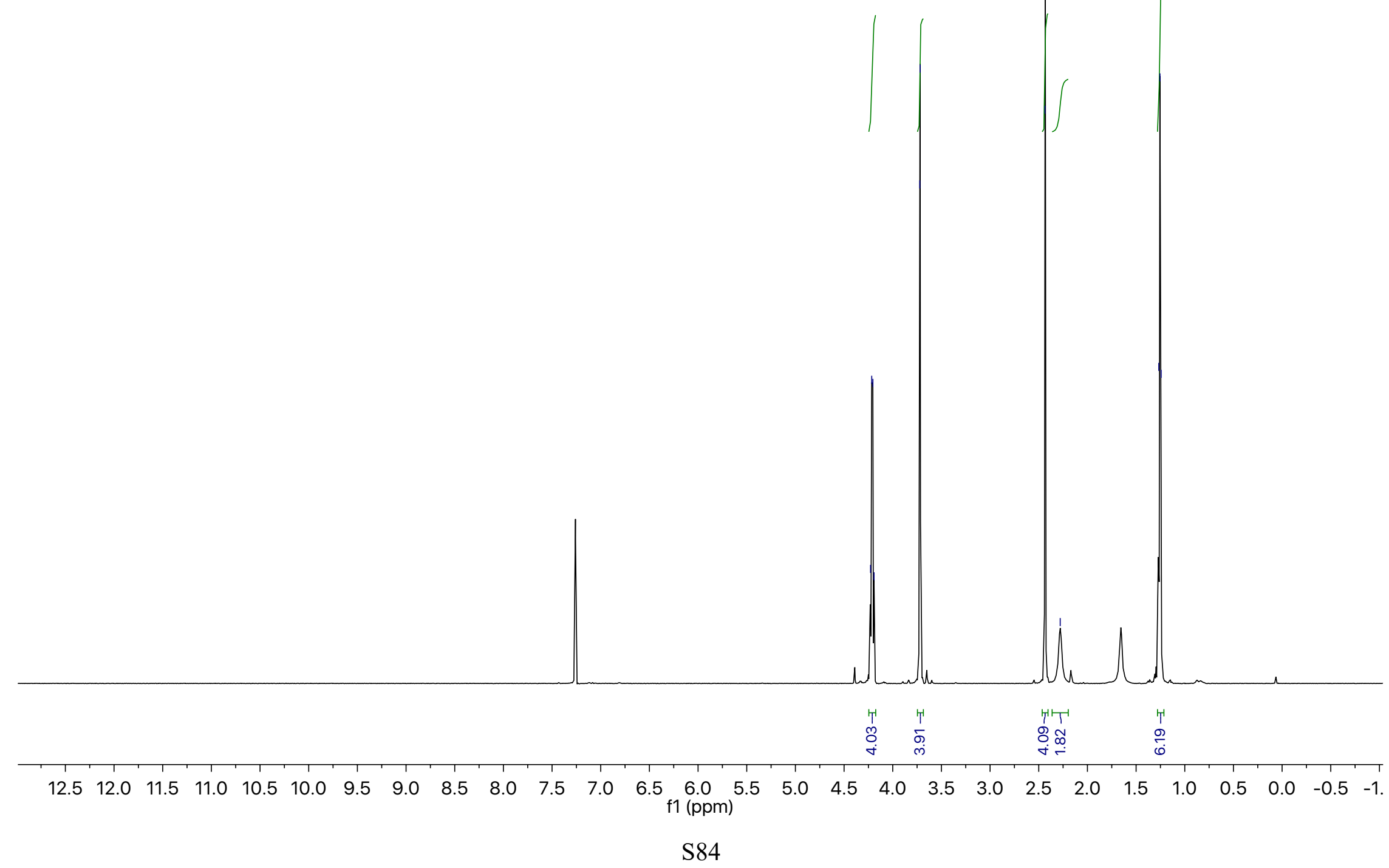




\section{Compound $18{ }^{13} \mathrm{C}$ NMR}

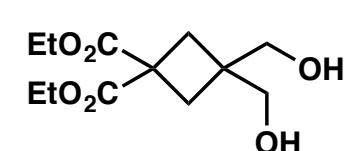

OH

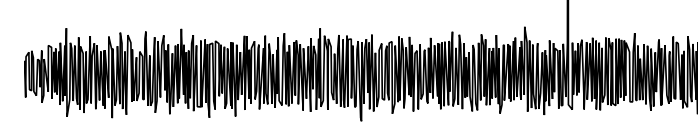
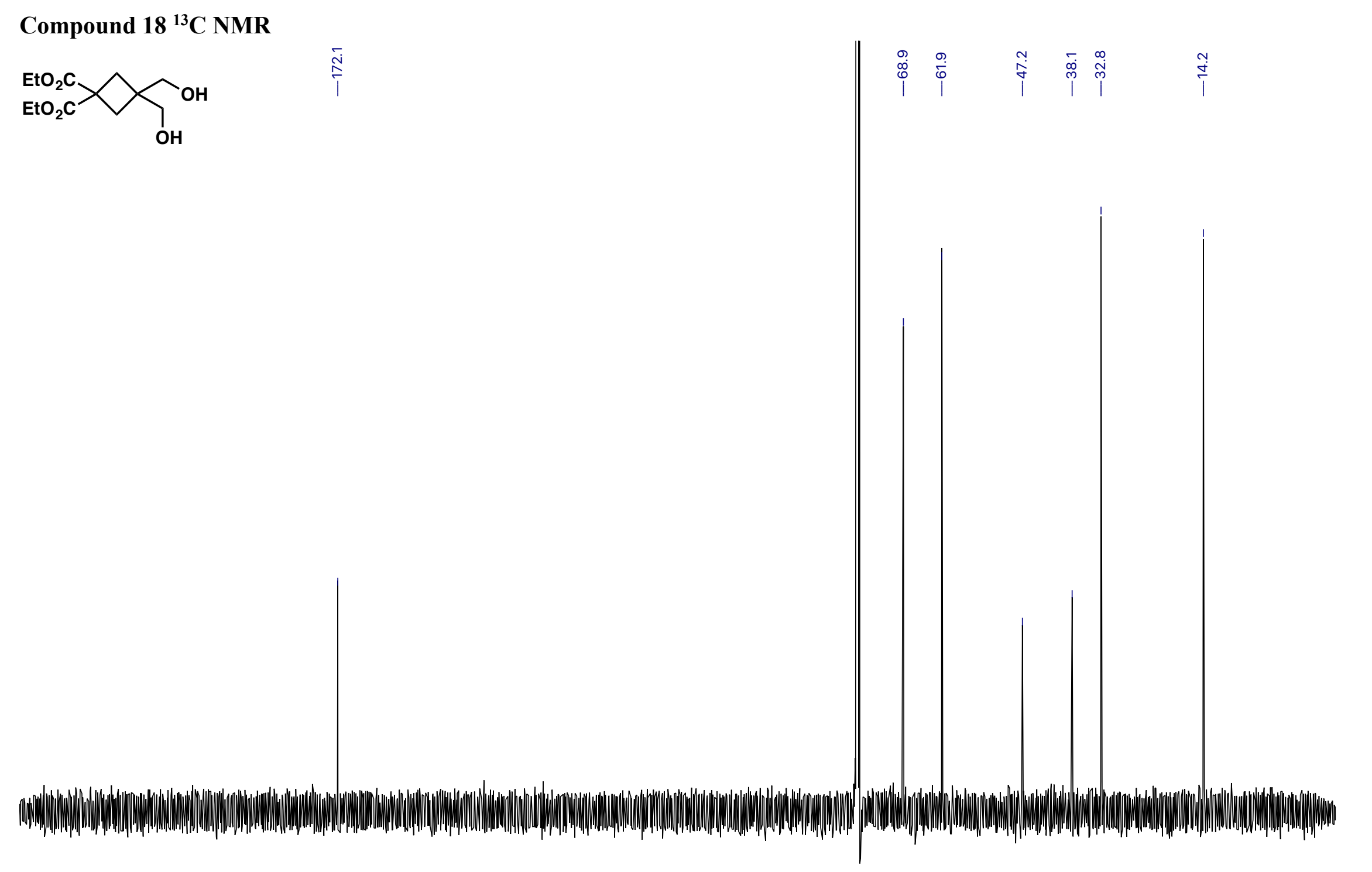

$30 \quad 220 \quad 210$

$200 \quad 190$

180

$170 \quad 160$

150

$140 \quad 130$

$120 \underset{\mathrm{f} 1(\mathrm{ppm})}{110} 100$

$90 \quad 80$

60

50

$30 \quad 20$

100 


\section{Compound $7{ }^{1} \mathrm{H}$ NMR}

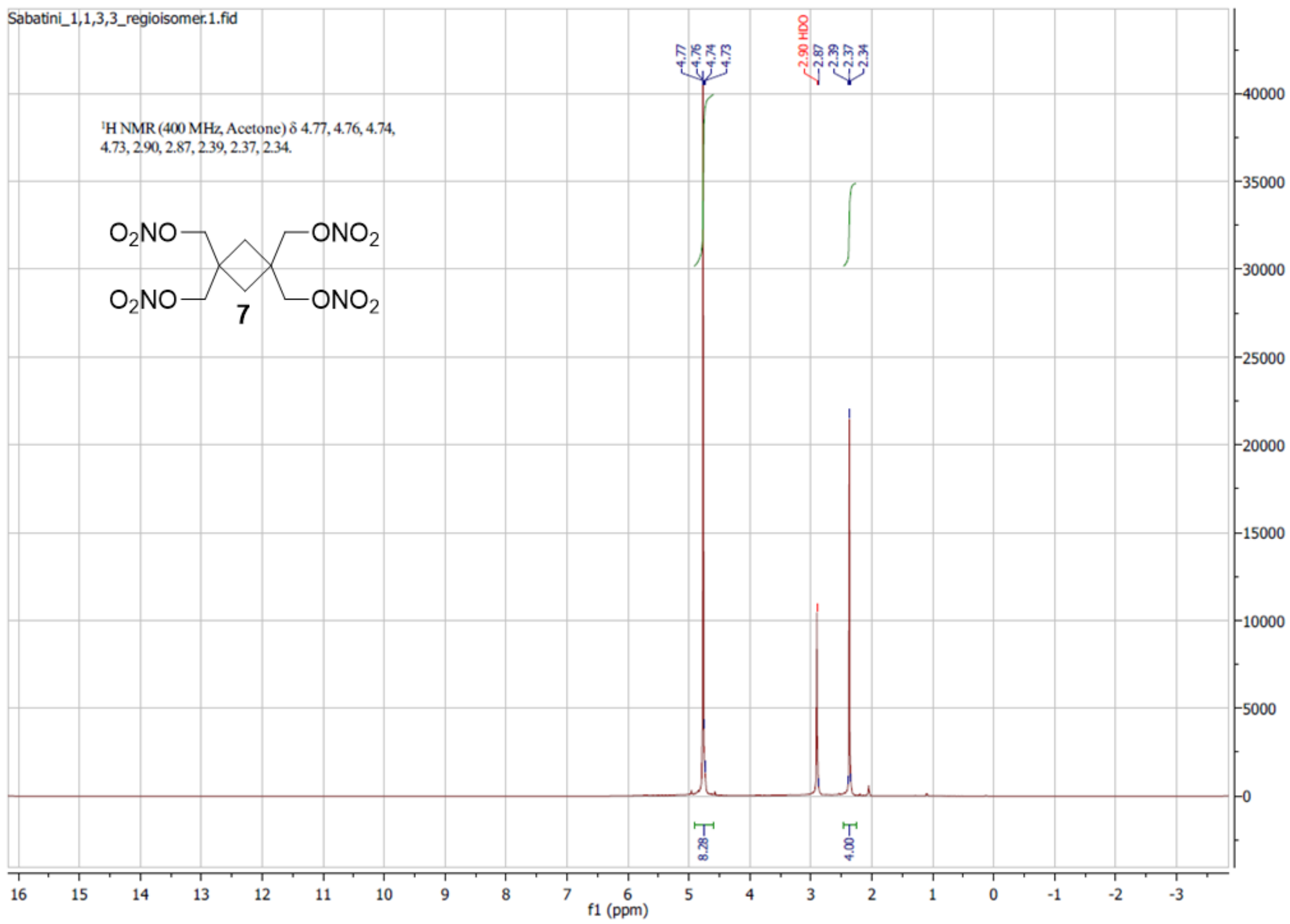




\section{Compound $7{ }^{13} \mathrm{C}$ NMR}

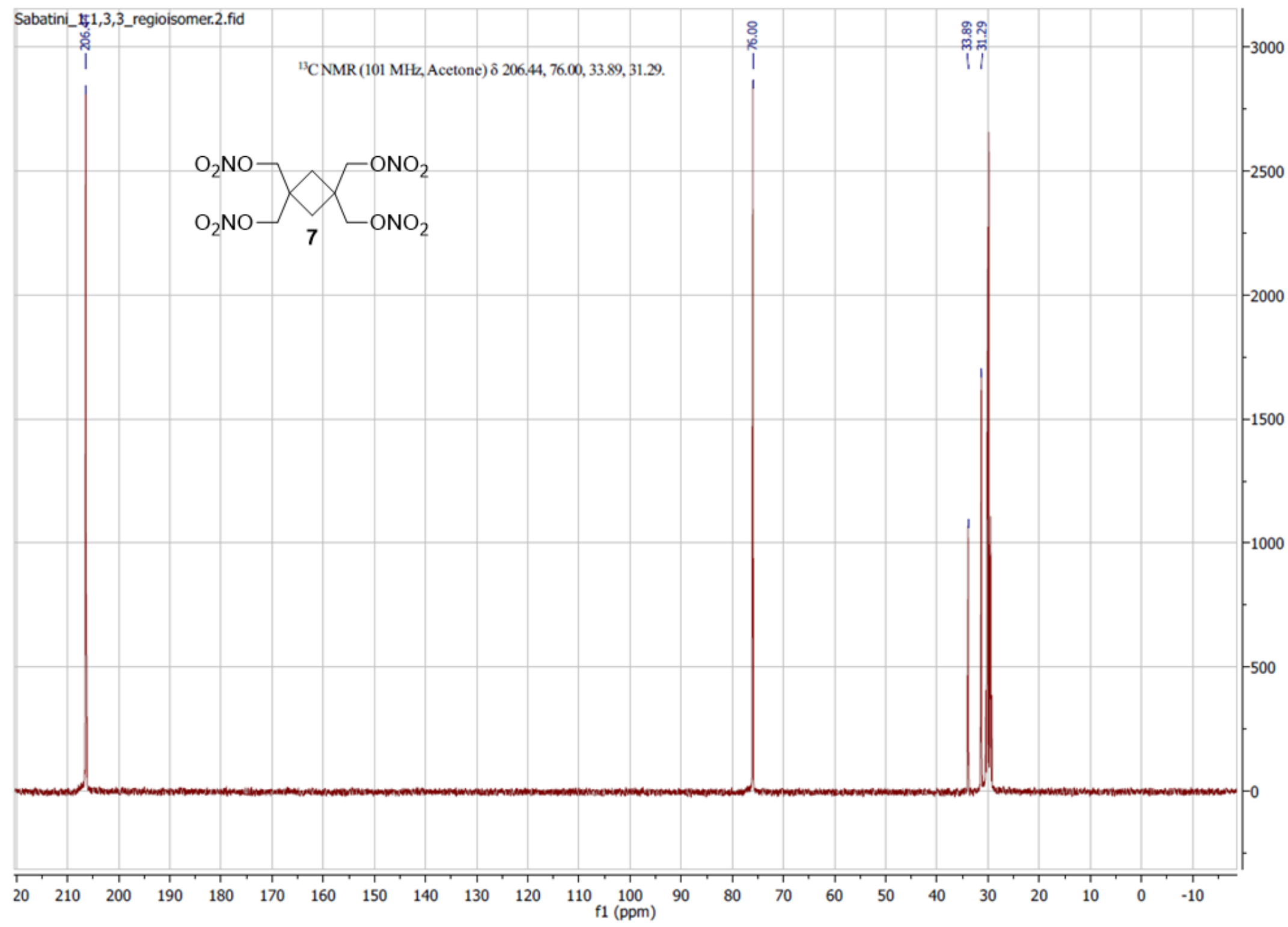


IR Spectra of Tetranitrates 2-7

Compound 2

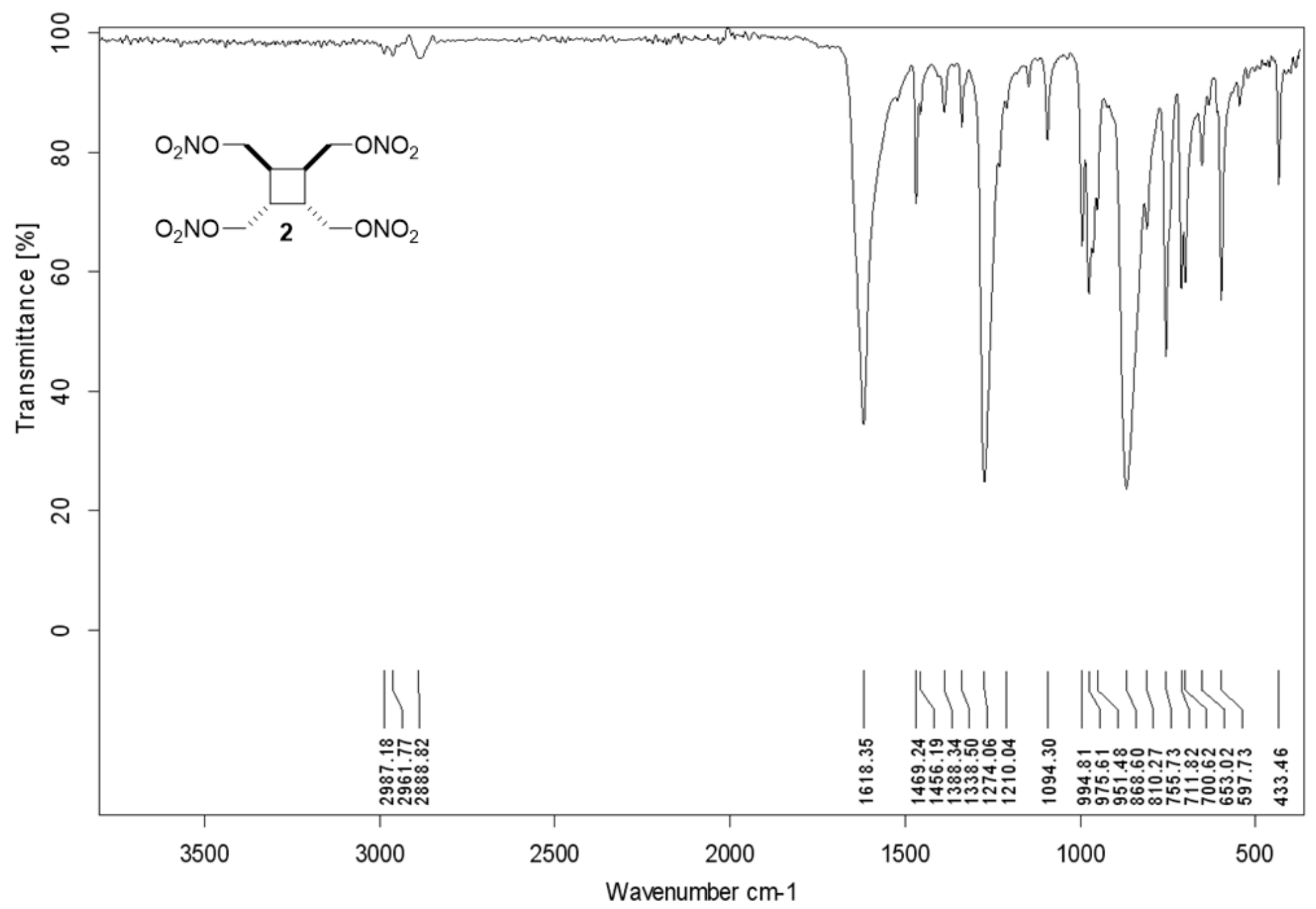




\section{Compound 3}

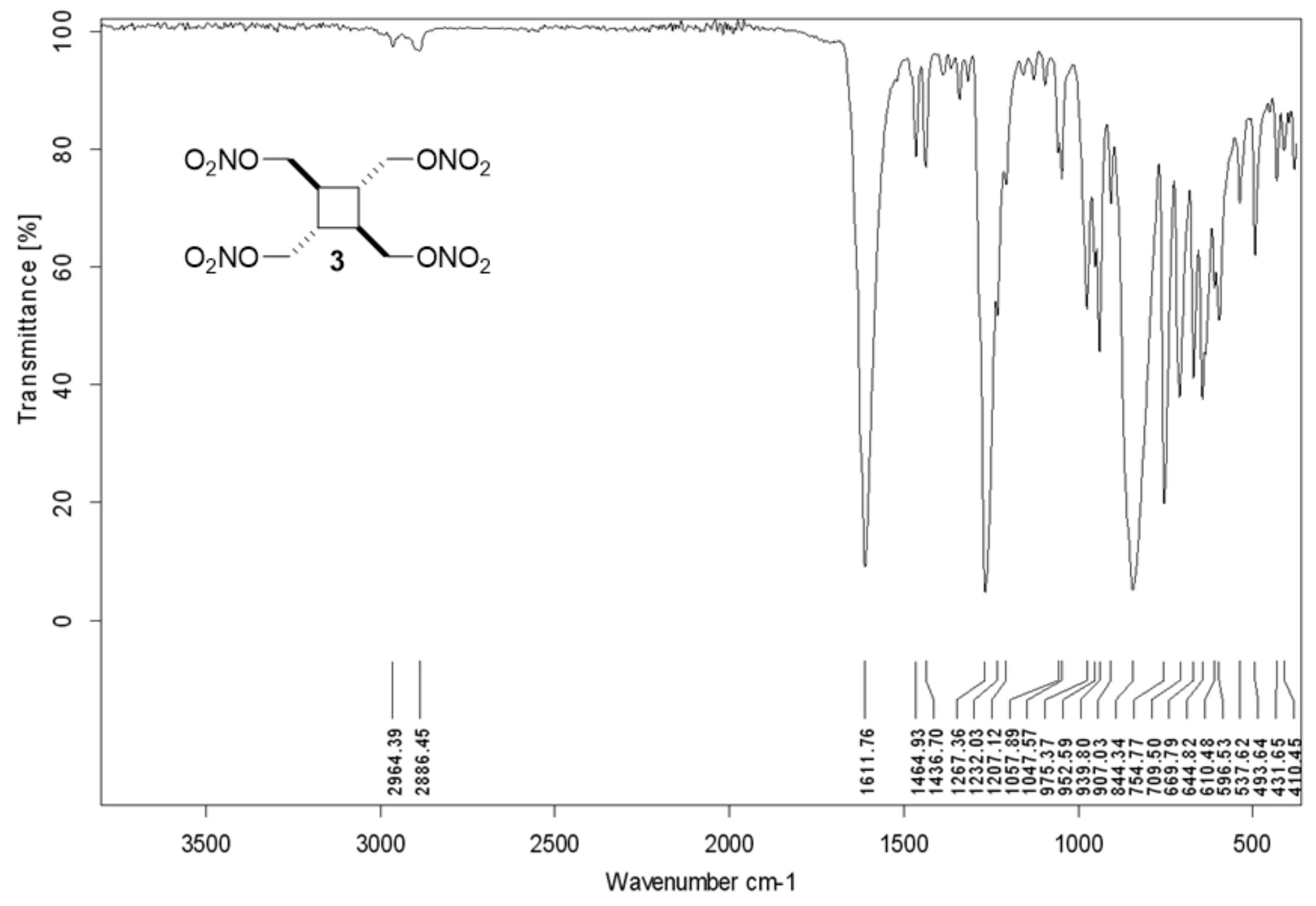




\section{Compound 4}

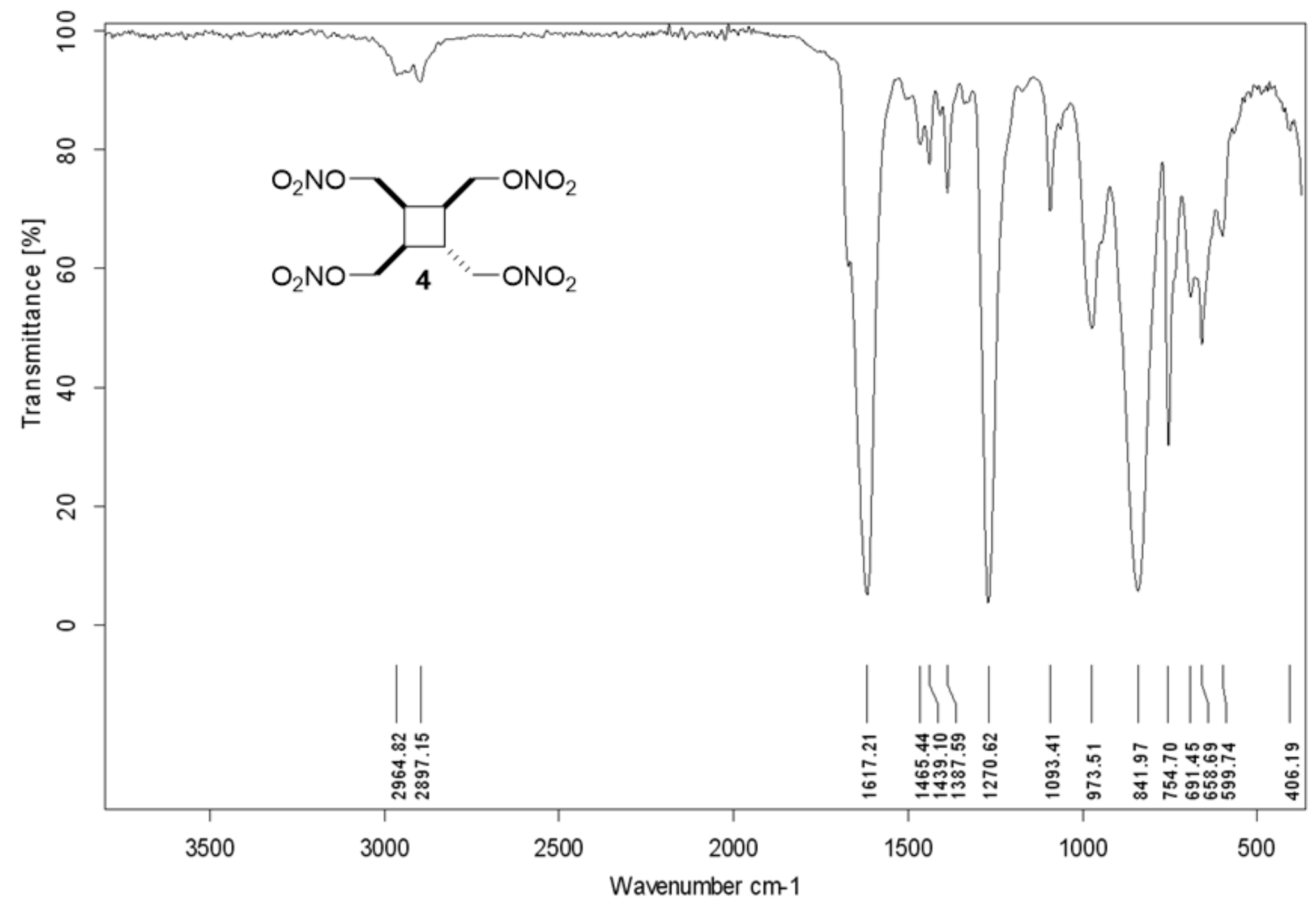




\section{Compound 5}

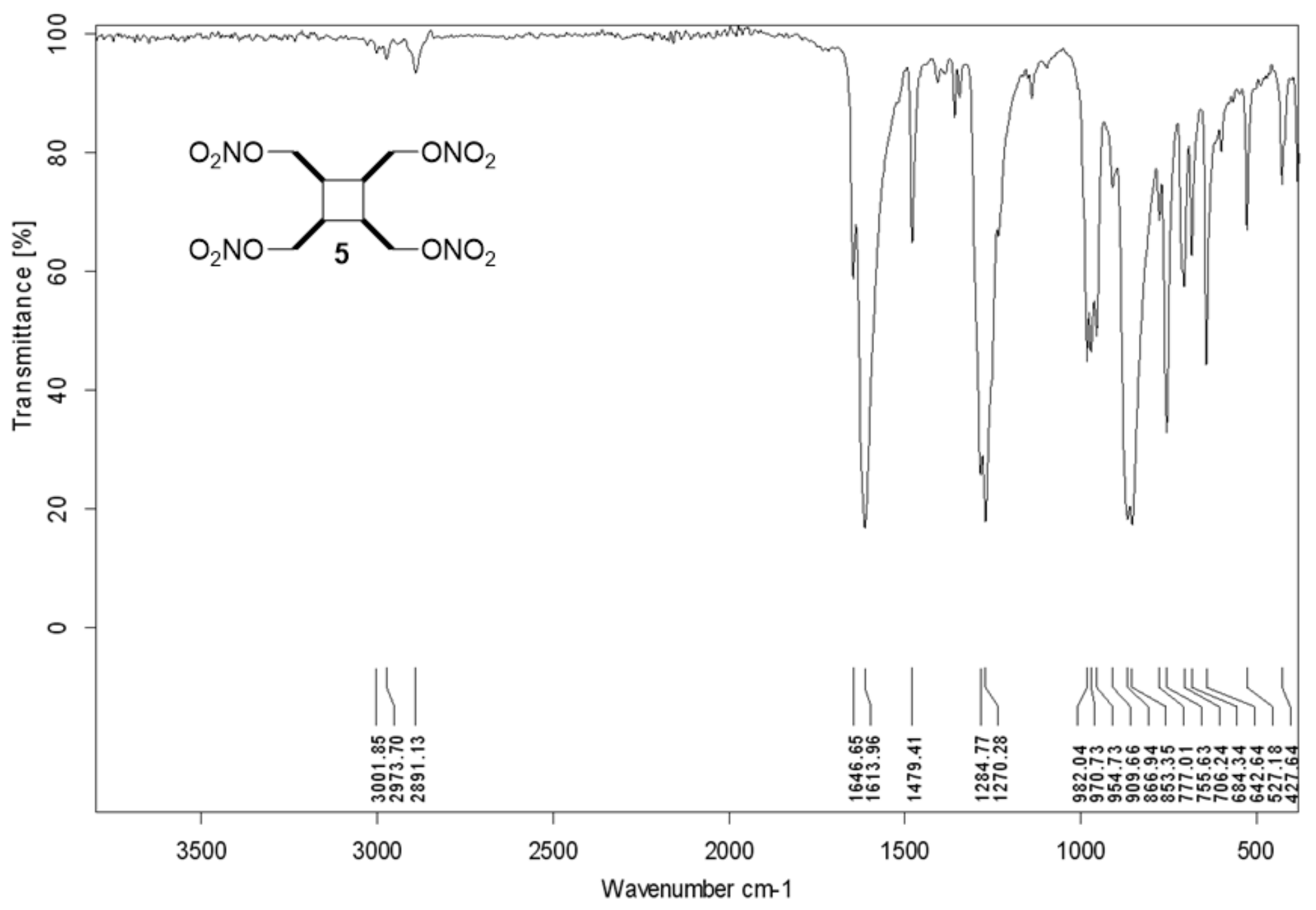




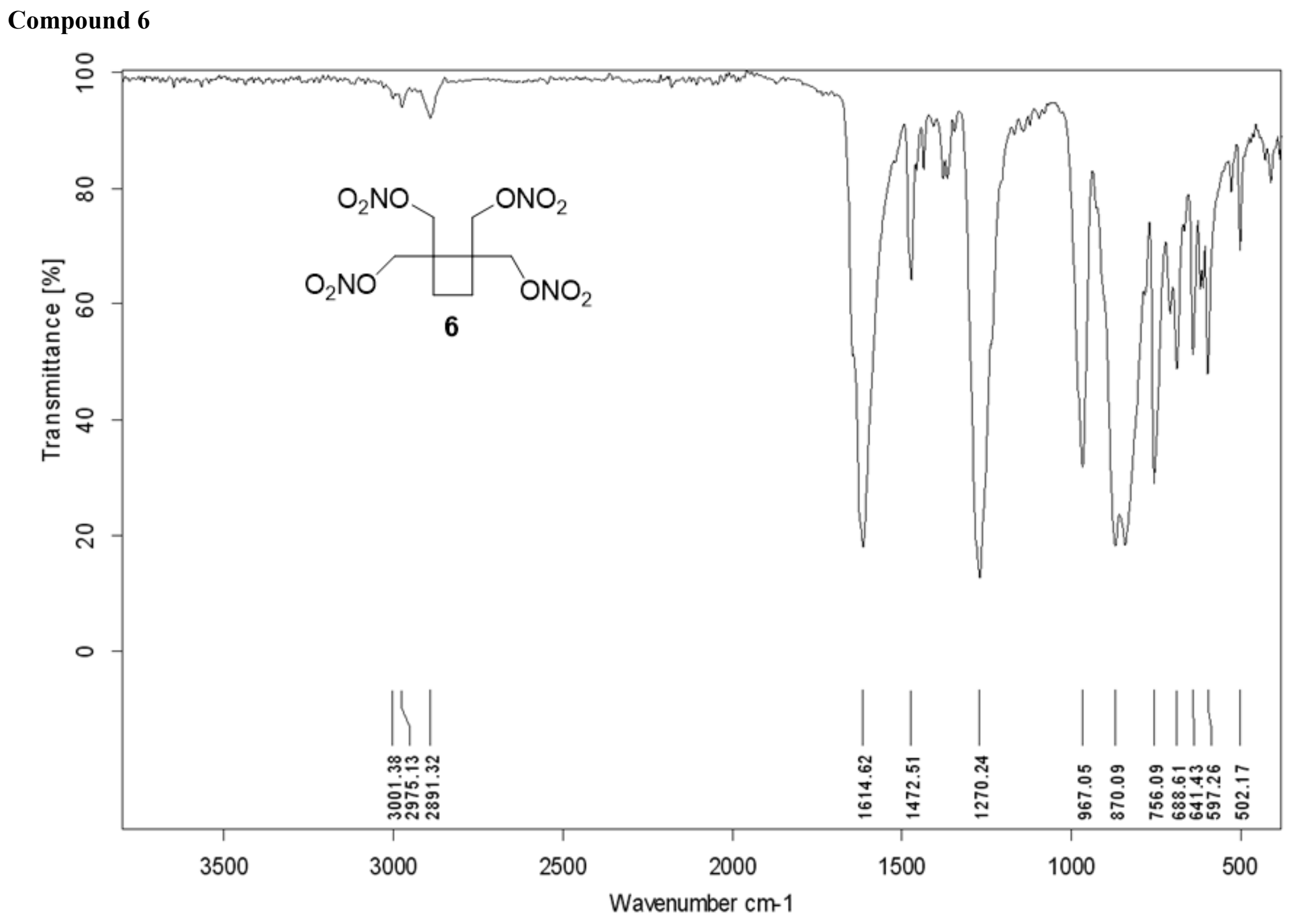




\section{Compound 7}

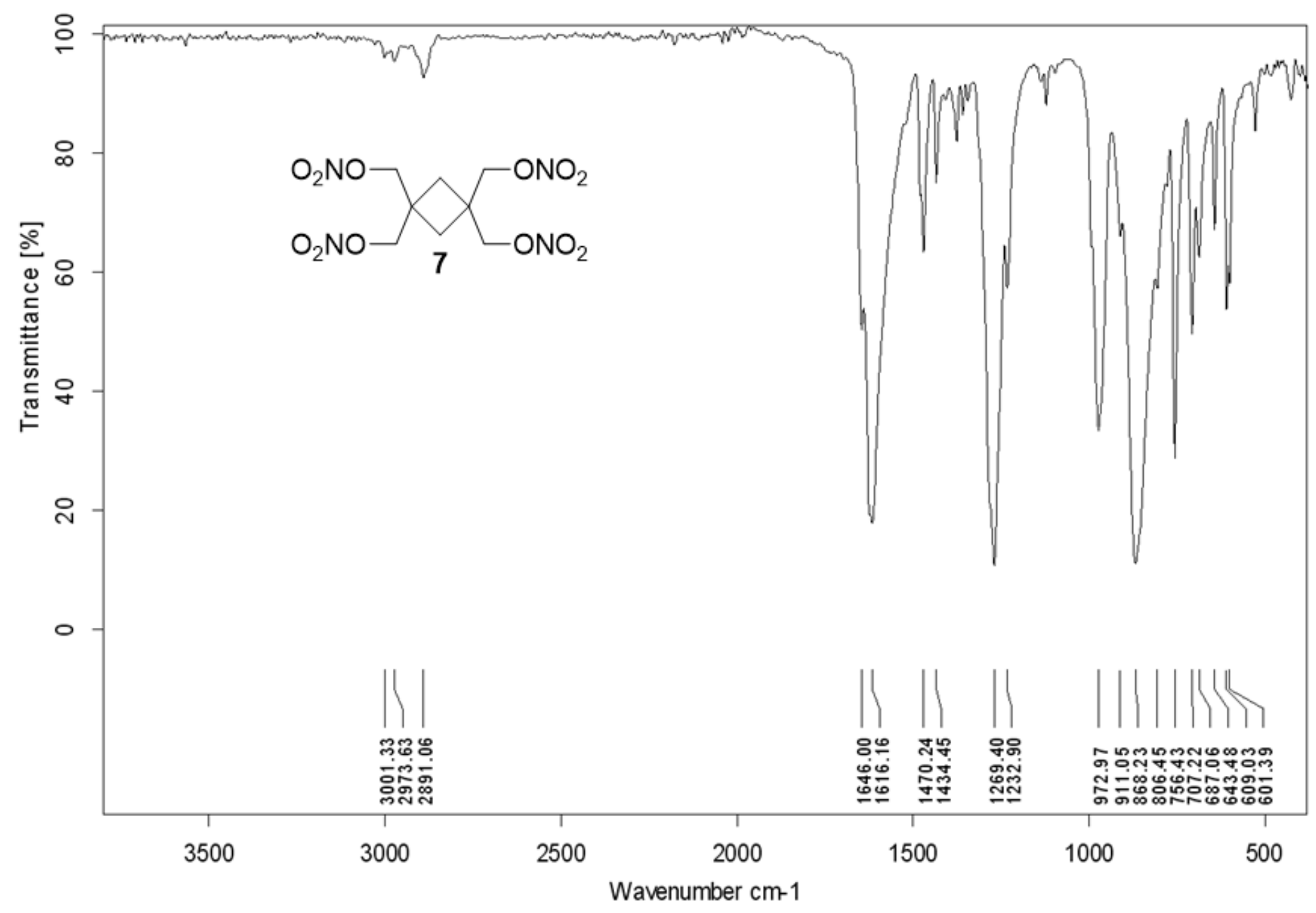


DSC Traces of Tetranitrates 2-7

Compound 2

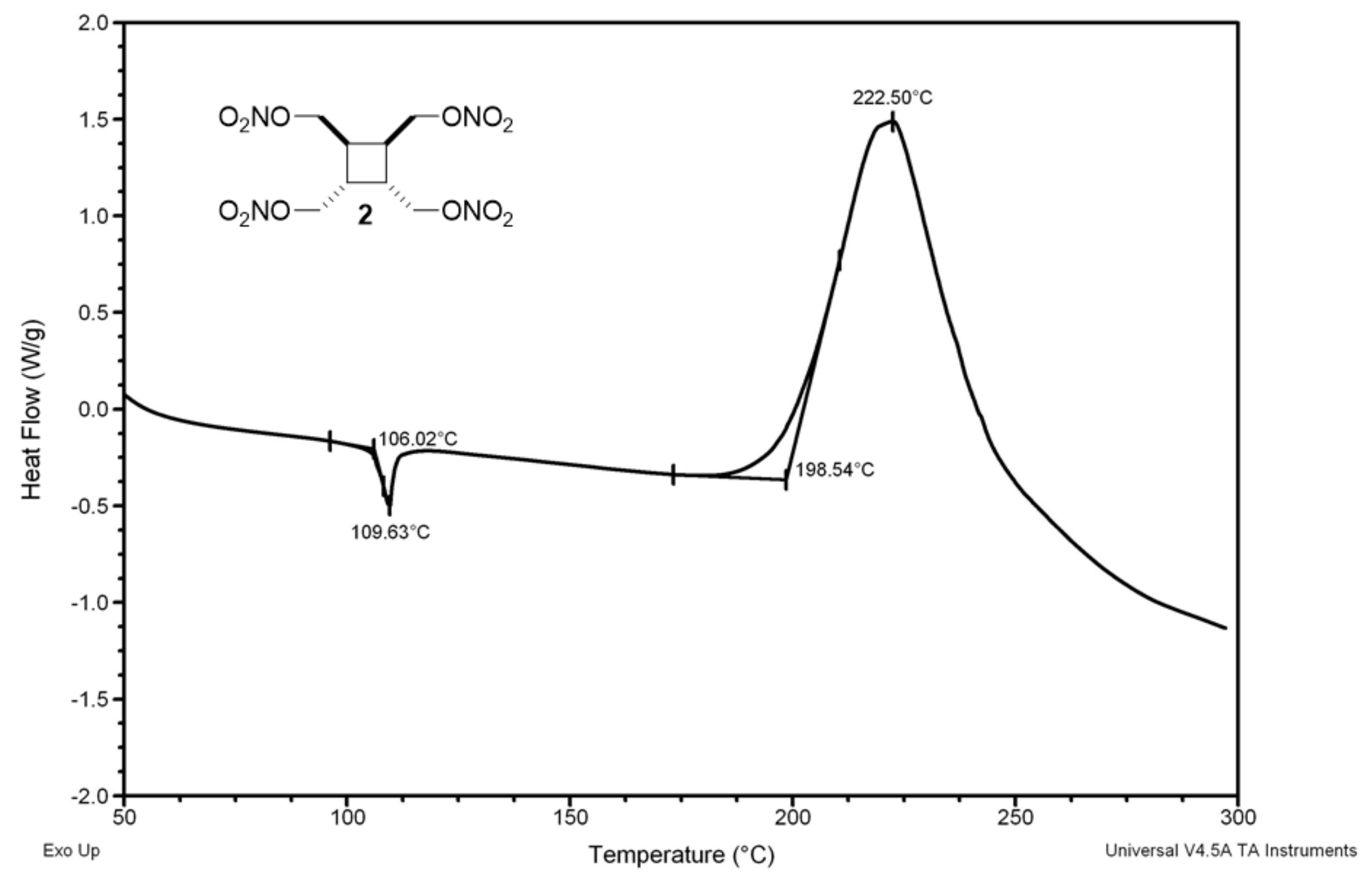


Compound 3

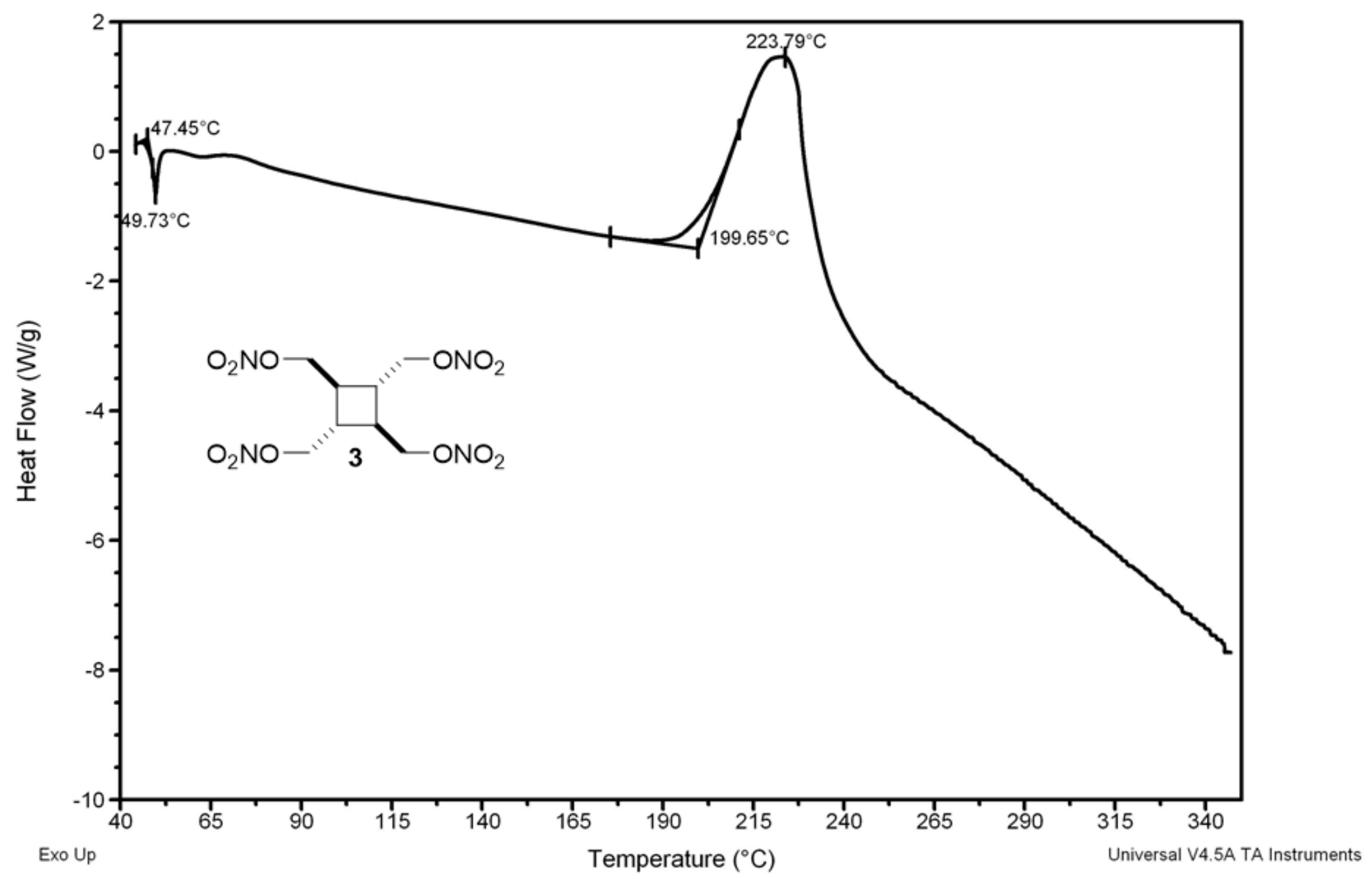


Compound 4

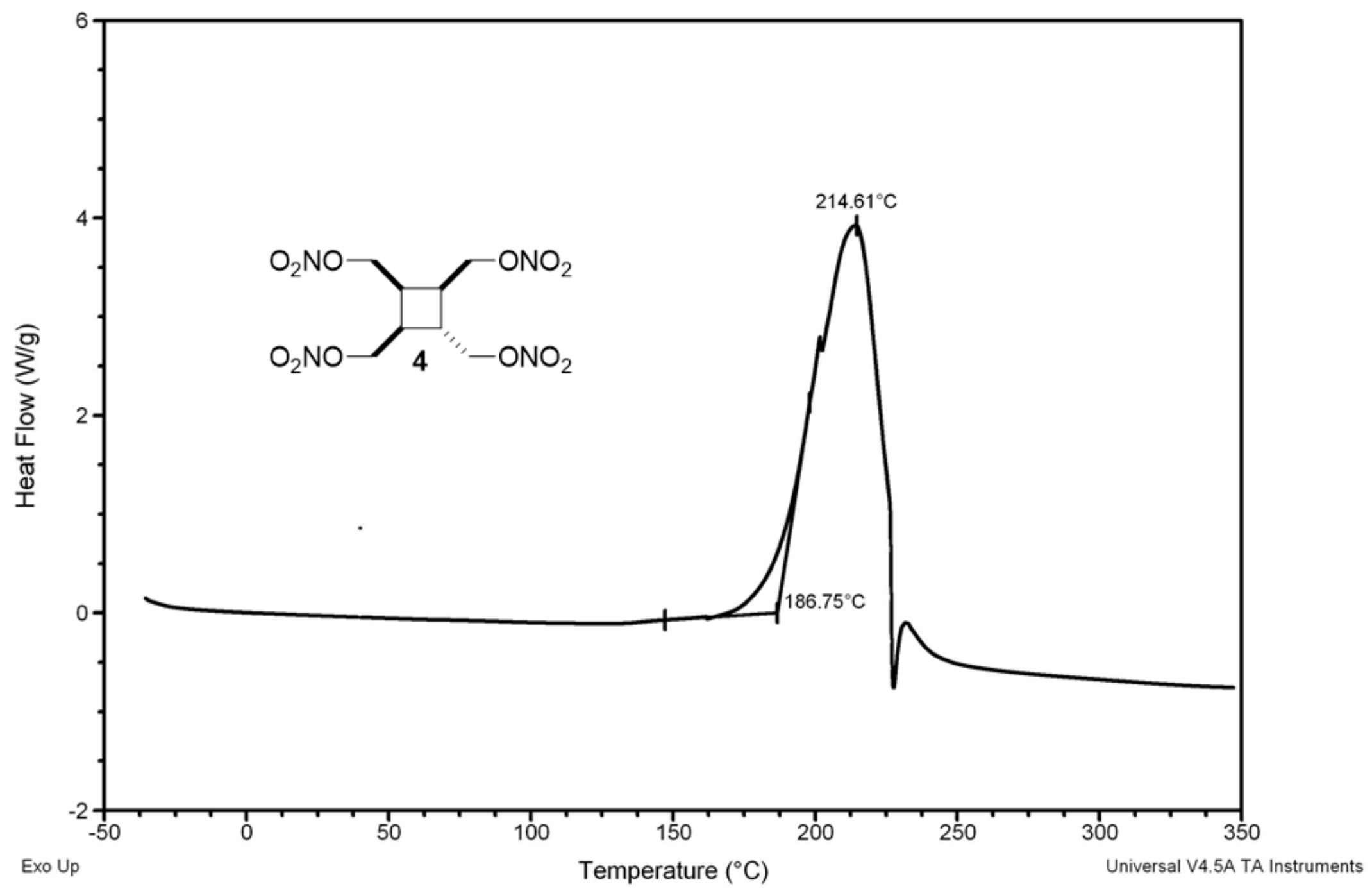




\section{Compound 5}

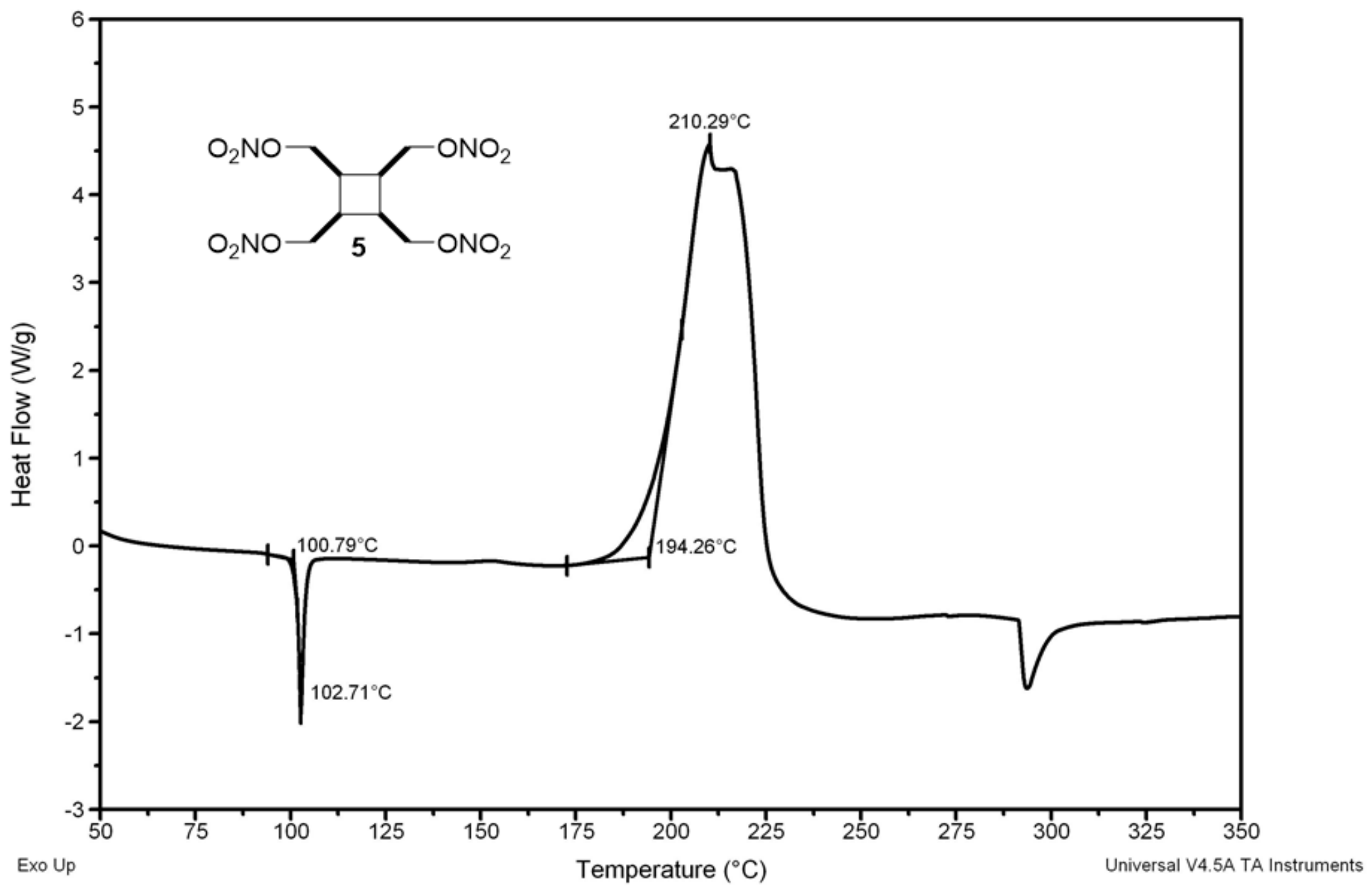




\section{Compound 6}

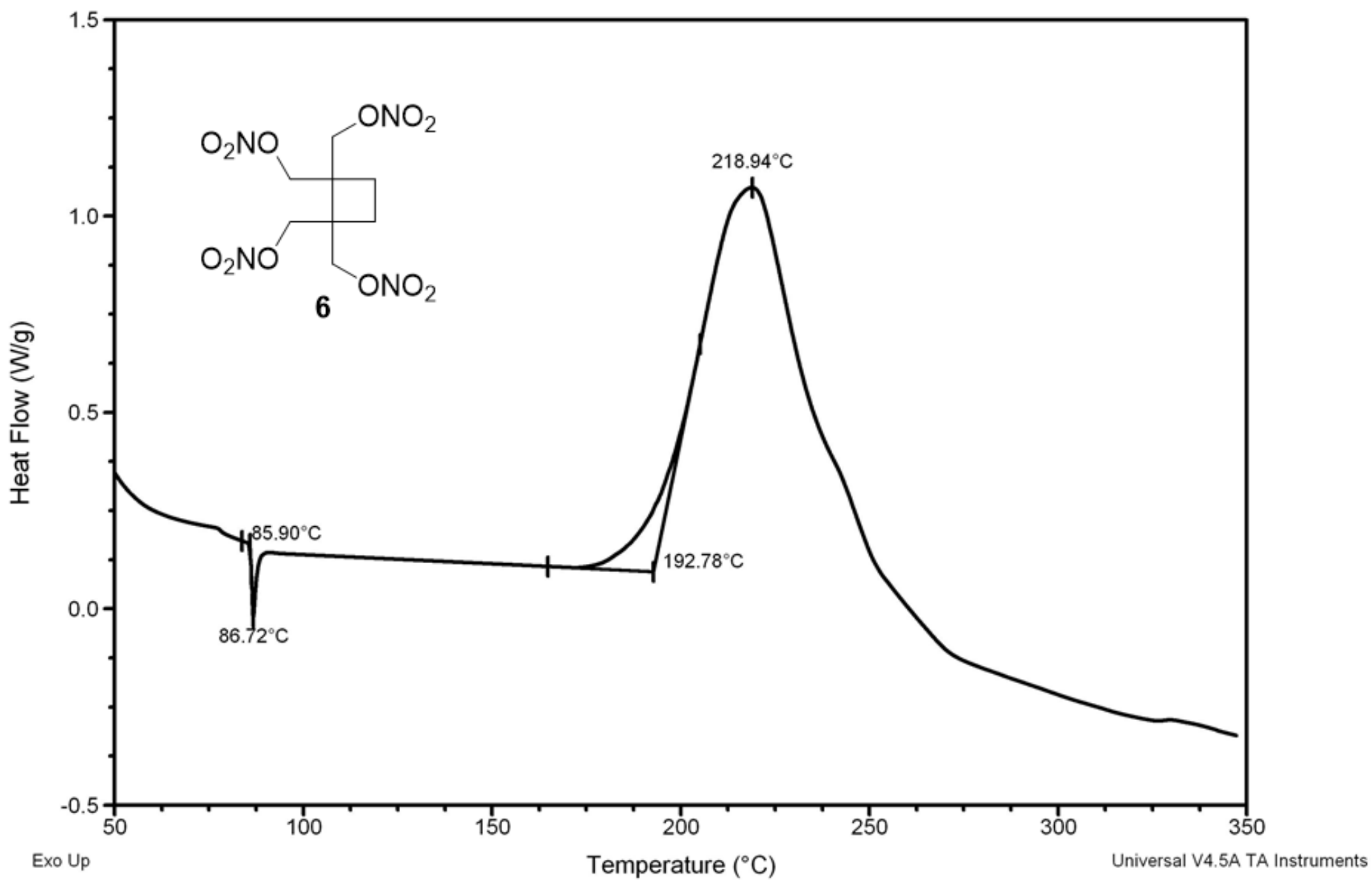


Compound 7

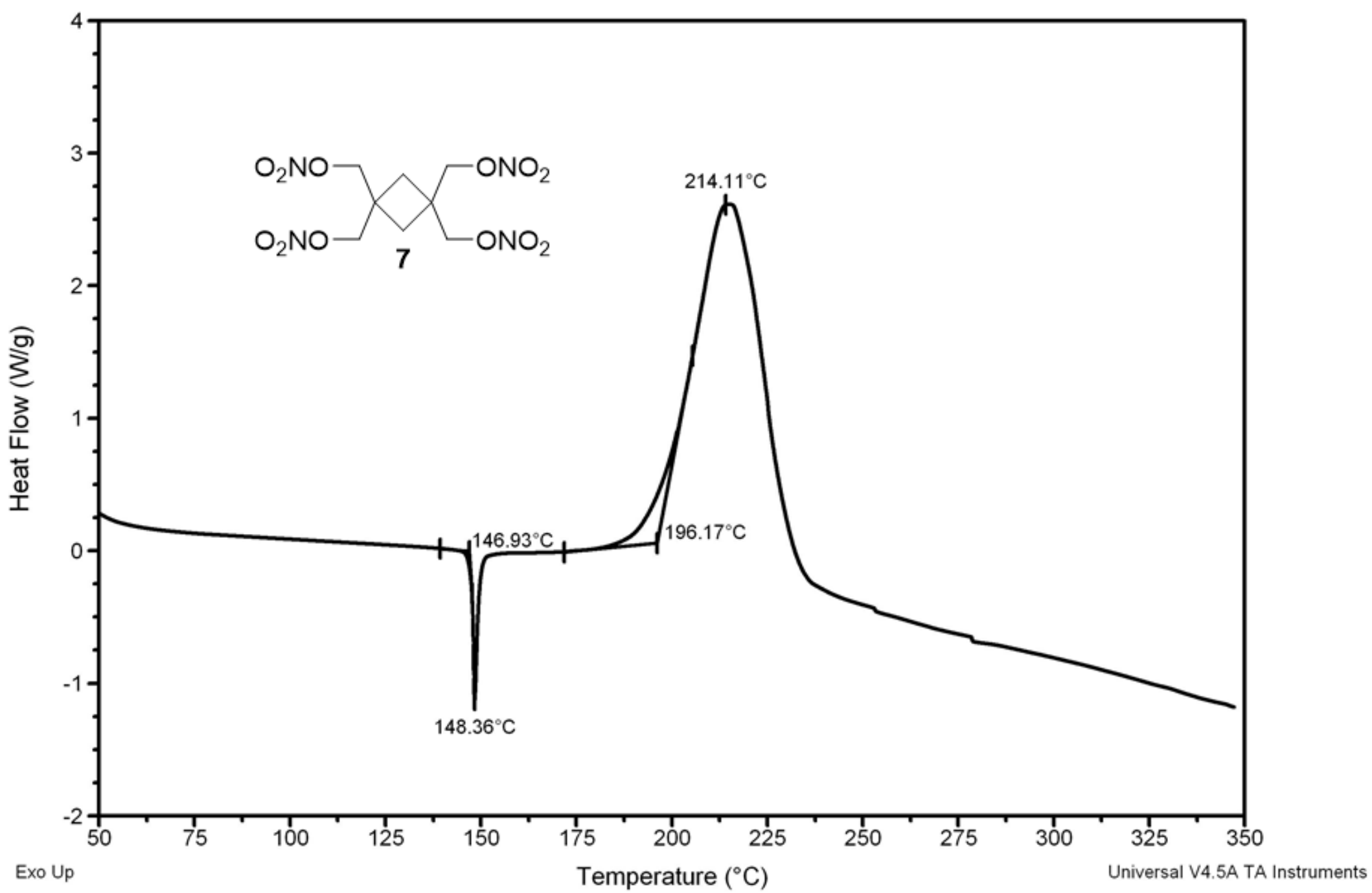




\section{References:}

1. Lai, M. C.; Chang, C. W.; Ong, C. W. Cyclobutanetetracarboxylate Compound and Preparation Method Thereof. US Patent US20060089505A1, 2006

2. Suzuki, H.; Tamura, T. Cage-Shaped Cyclobutanoic Dianhydrides and Process for Production Thereof. European Patent EP1813592A1, 2005.

3. Barr, K. J.; Scott, M. E.; Thompson, C. F.; Anthony, N.; Cammarano, C. M.; Bakshi, R. K.; Mohanty, S. K.; Korapala, C. S.; Latthe, P. R.; Kambam, V. N.; Sarkar, S. K.; Thatai, J. T. Pyrrolidine derived beta 3 adrenegic receptor agonists. US Patent US9486448B2, 2016

4. Yavari, I.; Nourmohammadian, F. Stereoselective Synthesis of Tetraalkyl Cyclobutene-1,2,3,4-tetracarboxylates. Synthesis of Tetraalkyl (Z,Z)-Buta-1,3-diene-1,2,3,4-tetracarboxylates. J. Chem. Research 1999, 512-513

5. Elinson, M. I.; Fedukovich, S. K.; Ugrak, B. I.; Nikishin, G. I. Electrochemical Oxidation of Tetramethyl Esters of $\alpha, \alpha, \omega, \omega-$ Alcanetetracarboxylic Acids. Russ. Chem. Bull. 1992, 41, 1827-1833

6. Li, C.; Kawamata, Y.; Nakamura, H.; Vantourout, J. C.; Liu, Z.; Hou, Q.; Bao, D.; Starr, J. T.; Chen, J.; Yan, M.; Baran, P. S. Electrochemically Enabled, Nickel-Catalyzed Amination. Angew. Chem. Int. Ed. 2017, 56, 13088-13093

7. Pecquet, P.; Huet, F.; Legraverend, M.; Bisagni, E. Synthesis of New Carbocyclic Analogues of Oxetanocin A and Oxetanocin G. Heterocycles 1992, 34, 739-745. 